\title{
"In, But Not of, Europe": Discussions of British National Identity in Post-War Europe
}

\author{
by
}

Margaret Louise Summerfield

\begin{abstract}
A thesis submitted to the Faculty of Graduate and Postdoctoral Affairs in partial fulfillment of the requirements for the degree of

Master of Arts

in
\end{abstract}

European, Russian and Eurasian Studies

Carleton University

Ottawa, Ontario

(C) 2011, Margaret Louise Summerfield 
Library and Archives

Canada

Published Heritage

Branch

395 Wellington Street

Ottawa ON K1A ON4

Canada
Bibliothèque et

Archives Canada

Direction du

Patrimoine de l'édition

395 , rue Wellington

Ottawa ON K1A ON4

Canada
Your file Votre référence

ISBN: 978-0-494-91582-0

Our file Notre référence

ISBN: $978-0-494-91582-0$
NOTICE:

The author has granted a nonexclusive license allowing Library and Archives Canada to reproduce, publish, archive, preserve, conserve, communicate to the public by telecommunication or on the Internet, loan, distrbute and sell theses worldwide, for commercial or noncommercial purposes, in microform, paper, electronic and/or any other formats.

The author retains copyright ownership and moral rights in this thesis. Neither the thesis nor substantial extracts from it may be printed or otherwise reproduced without the author's permission.
AVIS:

L'auteur a accordé une licence non exclusive permettant à la Bibliothèque et Archives Canada de reproduire, publier, archiver, sauvegarder, conserver, transmettre au public par télécommunication ou par l'Internet, prêter, distribuer et vendre des thèses partout dans le monde, à des fins commerciales ou autres, sur support microforme, papier, électronique et/ou autres formats.

L'auteur conserve la propriété du droit d'auteur et des droits moraux qui protege cette thèse. $\mathrm{Ni}$ la thèse ni des extraits substantiels de celle-ci ne doivent être imprimés ou autrement reproduits sans son autorisation.
In compliance with the Canadian Privacy Act some supporting forms may have been removed from this thesis.

While these forms may be included in the document page count, their removal does not represent any loss of content from the thesis.
Conformément à la loi canadienne sur la protection de la vie privée, quelques formulaires secondaires ont été enlevés de cette thèse.

Bien que ces formulaires aient inclus dans la pagination, il n'y aura aucun contenu manquant. 


\begin{abstract}
Britain applied for membership in the European Economic Community in 1961. This act set off a series of debates about Britain's role in Europe and international relations. These debates had little to do with actual foreign policy; instead they were primarily about the amorphous question of identity. I examined the public re-evaluation of national identity after the Second World War, as the Empire ended and European integration began, focusing on the Commonwealth Prime Ministers' Conference in September 1962. Imperial images continued to capture public imagination long after the Empire dissolved, indicating a deeply held conviction that British identity and the Empire were innately linked. Through the press's discussion of European integration and the Commonwealth, I analysed the discourse used in the post-war redefinition of British national identity in Britain. The British Empire was dissolved after the Second World War, but its legacy continued to inform the construction of national identity.
\end{abstract}




\section{Acknowledgements}

First and foremost, thanks are owed to my supervisor, Y.A. Bennett, who was charged with helping me transform a fascination with the role of the press and an interest in national identity into a coherent research project. She has been an unending source of encouragement, has challenged every aspect of the project, and has never let me settle for mediocrity. Thank you for making my graduate school experience so positive. You are a consummate teacher.

Many other faculty members have played a role in forming this thesis. Jeff Sahadeo first introduced me to the idea of national identity as a research topic, Matthew McKean fed my love of Britain, whereas Jennifer Evans has encouraged me to remember the wider European context of the British experience. Thanks must also be extended to Ginette Lafleur, who has kept me abreast of administrative matters throughout the last two years.

Of course I must acknowledge the other students from various disciplines who have offered a fruitful forum for discussion, including Andrea Reid, Kathryn Desplanque, Justin Rivest and Ceilidhe Wynn. Erin Bell has, in particular, challenged me to remember the colonised in my study of the British Empire.

None of this would be possible without the unending support of my family. My parents, John and Virginia Summerfield, have always been my number one supporters, and I have truly been blessed to know that they were always behind me, no matter how kooky the idea. My brothers, John and Ian, have been my dearest friends since childhood, teaching me to argue coherently. I know my passion confuses you, but along with Chloe, I could not ask for a better support system. My inspiration is my 
grandmother, Lillian Summerfield, who has imparted to her grandchildren a love of history. To Katya, Abby and, most of all, Jack - the truest of true friends.

Finally, to Jon. Without your constant love and support, your critiques and your challenges, this work would have suffered greatly. You believed in me when I could not believe in myself. Your presence in my life is my greatest blessing, and I am truly thankful to be able to share my life and work with such an incredible scholar. 


\section{Table of Contents}

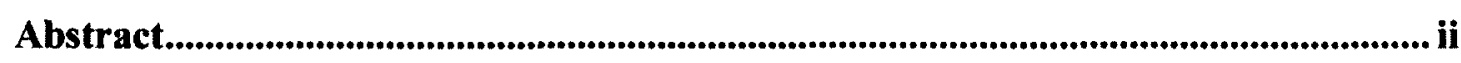

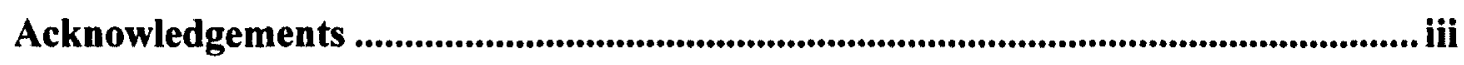

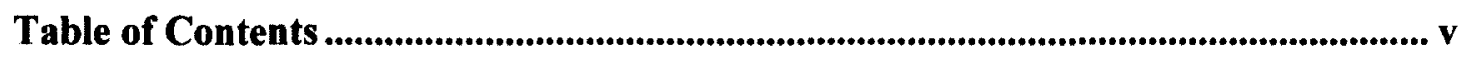

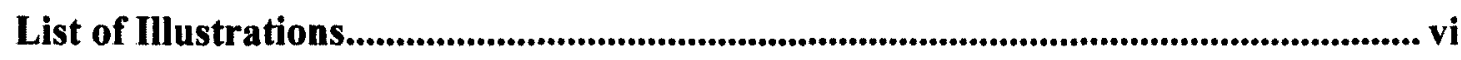

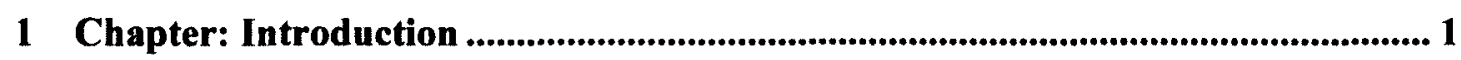

2 Chapter: A Family Reunion - the Commonwealth Conference.......................... 38

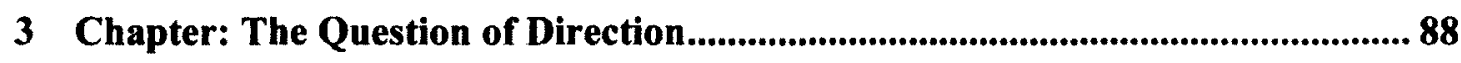

4 Chapter: The Europeanization of Britain in the French Press ............................ 126

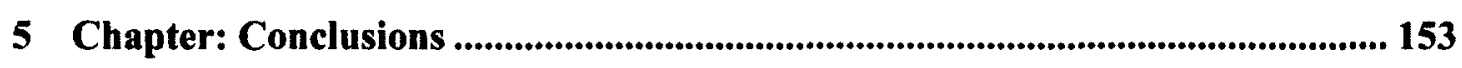

Appendix: Cartoon Representations of the Franco-German Rapprochement....... 165

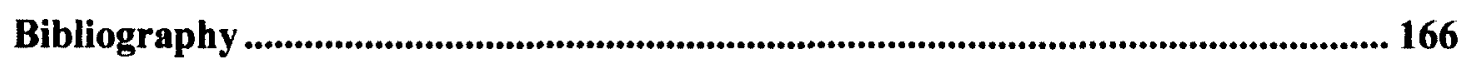


Please note:

\author{
All illustrations have been \\ blocked out by author for \\ copyright reasons.
}




\section{List of Illustrations}

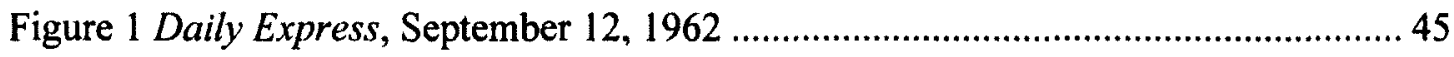

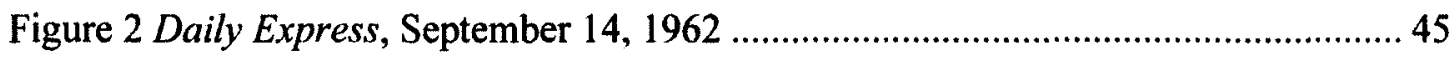

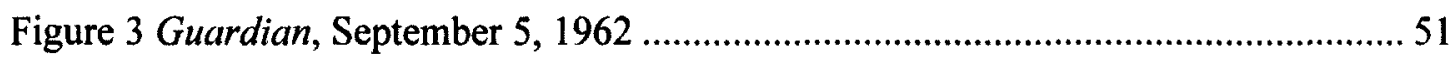

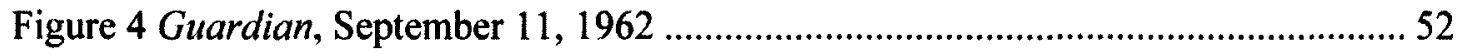

Figure 5 Daily Express, September 13, 1962 .............................................................. 54

Figure 6 Daily Express, September 14, 1962 ............................................................ 54

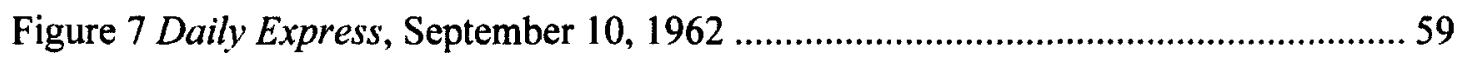

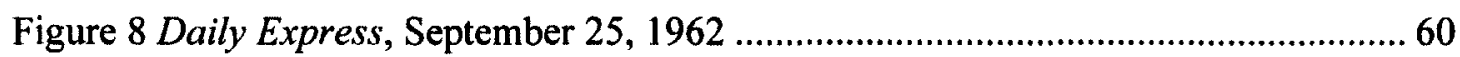

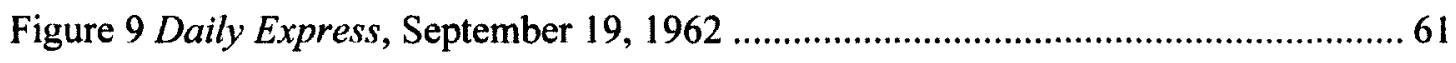

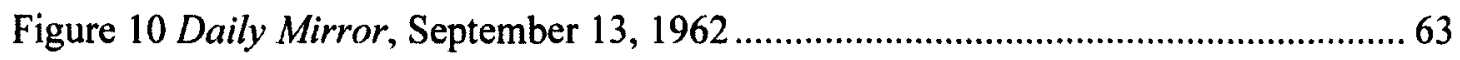

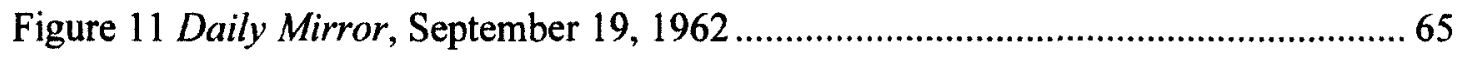

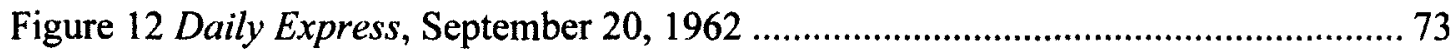

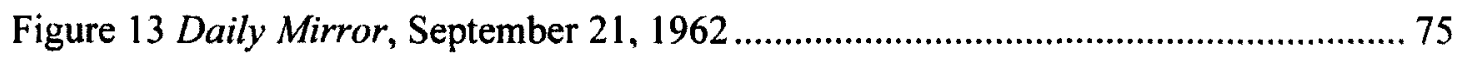

Figure 14 Daily Express, September 22, 1962 ........................................................... 84

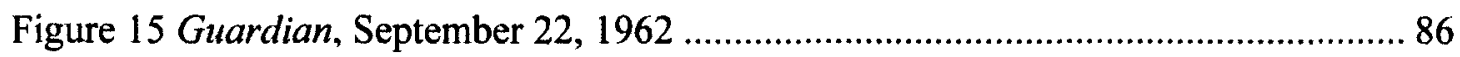

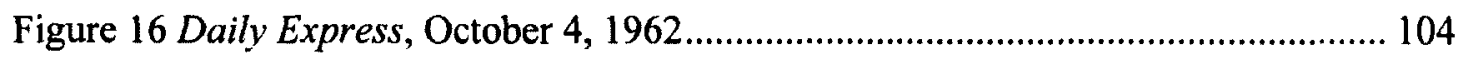

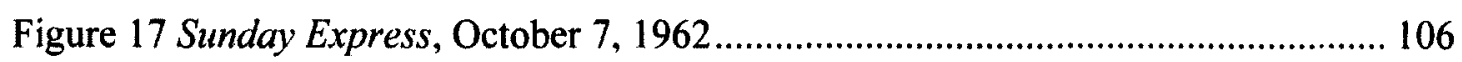

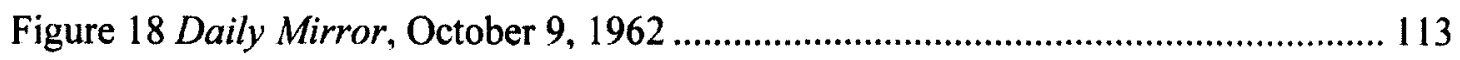

Figure 19 Daily Express, October 11, 1962 ............................................................. 117

Figure 20 Daily Express, October 12, 1962 ......................................................... 118

Figure 21 Sunday Express, October 14, 1962 …………………………………..... 122 


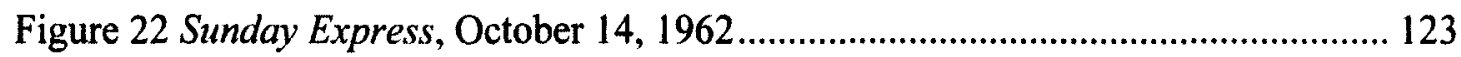

Figure 23 Cartoon by Opland on British membership in the EEC (August 4, 1962) .... 126

Figure 24 Cartoon by Behrendt on British membership in the EEC (September 1962). 127

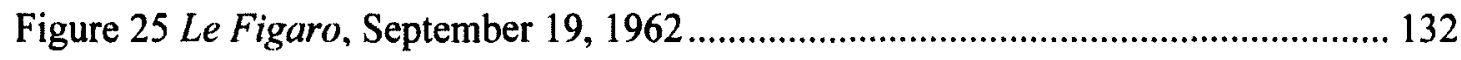




\section{Chapter: Introduction}

Britain has never been a particularly enthusiastic member of the European Union. When the common European currency, the Euro, began circulation in 2002, Britain was one of the few members of the European Union to negotiate an exemption. ${ }^{1}$ Indeed, the belief that European integration is irreconcilable with British cultural and national identity has enjoyed widespread currency since the end of the Second World War. Both British 'Euroscepticism', and outright opposition to European integration and the European Union are often explained by reference to geography, history, economics and a media campaign that propagates the idea that British and European identities are incompatible. $^{2}$

This project examines the relationship between British ambivalence towards European integration and the post-war redefinition of British national identity through the lens of major British daily newspapers. The post-war press was very concerned about Britain's role in Europe, and the future of the British Empire. These debates had little to do with foreign policy, but were primarily concerned with the question of British identity, since many British politicians, and members of the British public, feared that the country

1 Denmark and the United Kingdom obtained legal opt-outs in the Maastricht Treaty. Sweden gained a de facto opt-out by using a legal loophole. While Sweden is legally required to join the Euro, it has deliberately not fulfilled the convergence criteria. Lars Jonung, "The Political Economy of Monetary Unification: The Swedish Euro Referendum of 2003," Cato Journal 24, no. 1-2 (2004): 126.

2 Peter Shearman, "Britain, the European Union and National Identity," in Britain in Europe: Prospects for Change. ed. John Milfull (Ashgate: Aldershot, 1999), 91-102; Charles Grant, "Why is Britain Eurosceptic?" Centre for European Reform, 2, accessed October 17, 2011, http:/www.cer.org.uk/sites/default/files/publications/attachments/pdf/2011/essay_eurosceptic_19dec081345.pdf. According to the Oxford English Dictionary', the term 'Eurosceptism' was first used with irony in The Times on 11 November, 1985 to describe Lord Cockfield who advocated the loss of sovereignty to strengthen the EEC. Richard Owen, "Tomatoes Throw Europe's Summit Progress," The Times, November 11, 1985. A Eurosceptic is defined as "A person, especially a politician, having doubts or reservations regarding the supposed benefits of increasing cooperation between the member states of the European Union (and formerly the European Economic Community); an opponent of greater political or economic integration in Europe." Oxford English Dictionary, s.v. "Eurosceptic," accessed April 5. 2010, http://dictionary.oed.com/cgi/display/50295143?keytype=ref\&ijkey=.foBuqvMRxPys. 
faced a stark choice between membership in the European Economic Community (EEC) on the one hand and the continuation of its historic links with the Commonwealth on the other. This project investigates how these issues played out in the press, by focusing primarily on coverage of the London Commonwealth Prime Ministers Conference in 1962, which met to discuss how British participation in the Common Market would affect Commonwealth relations. ${ }^{3}$ British national identity was being re-forged during this period, and the issues debated in the press, to a significant extent, revolved around questions concerning what form this identity might assume. My work explores the role of the press in Britain's struggle to redefine its place in Europe and the wider world and, consequently, its very national identity.

I chose to focus on the Commonwealth Conference of 1962 because it gave Commonwealth leaders an opportunity to air their concerns on Britain's membership in the EEC. The primary purpose of the conference was to discuss whether membership would force a fundamental change to the nature of the Commonwealth. These meetings and their discussions about Britain's future in Europe resulted in a domestic debate over the foundations of national identity in Britain. Abroad and particularly in France, they also raised questions about Britain's suitability for participation in the Common Market. European integration required that members of the EEC form a single economic bloc, which was incompatible with continued imperial ties. The Commonwealth Conference demonstrated that Britons maintained their belief in the centrality of the Commonwealth.

\footnotetext{
${ }^{3}$ The EEC refers to the organisation that enables the Common Market. Britain's membership in the EEC would allow its participation in the Common Market. The two terms were used interchangeably by the press.
} 
This conception resulted in serious continental concerns about Britain's suitability for membership in the EEC.

The prime ministers' concerns reflected the fear that looser ties could break the remnants of the Empire apart with serious political and economic consequences for Britain and for the Commonwealth. ${ }^{4}$ Looser ties would also disturb cultural bonds by challenging the view that the Commonwealth shared a supranational sense of 'Britishness', while simultaneously localising 'Britishness,' to the islands of Great Britain, and thereby endangering traditional constructions of national identity. Since the result of Britain's application was pending at the time of the Commonwealth Conference, it provides an exceptional opportunity to investigate the nature of the public discussions of national identity and the degree to which these articulated an identification with Britain's traditional Imperial and Atlantic links, or whether they were focused on a new future in Europe.

Proponents of European integration wrestled with the historical legacies of the British Empire and traditional definitions of British national identity. The post-1945 period witnessed an increase in British involvement with continental Europe, in partnership with the United States, although many Britons perceived the links between Britain and continental Europe as weak. ${ }^{5}$ Indeed, redefinition of British identity in a

\footnotetext{
${ }^{4}$ Paradoxically, throughout this period many of the countries in the Commonwealth were asserting their political and economic independence from Britain. They were also fostering regional trade links with 'outside' nations, such as Canada with the United States, or African regional blocs. While there is no doubt that Britain remained an important trade partner, the centrality of the imperial preference system for economic stability was declining in Britain and throughout the Commonwealth. See George Wilkes, "The First Failure to Steer Britain into the European Communities: An Introduction," in Brifain's Failure to Enter the European Community, 1961-63, ed. George Wilkes (London: Frank Cass \& Co., 1997), 22.

${ }^{5}$ Stuart Ward, "The End of Empire and the Fate of Britishness." in History, Nationhood and the Question of Britain, eds. Helen Brocklehurst and Robert Phillips (New York: Palgrave MacMillan, 2004), 243.
} 
European context faced significant historical, cultural and ethnic hurdles, obstacles which my thesis hopes, in part, to explore.

British national identity is, by definition, an abstract concept. Since this type of identity is dependent upon an individual's self-identification with a community, it is challenging to precisely define what constitutes Britishness. Nonetheless, the idea of what constitutes the British nation has historically included certain assumptions about Britain's inhabitants and international role. I have defined three fundamental ideas about Britain which can be traced historically through the nineteenth century, and which continued to be relevant in the twentieth century. First, that Britain was destined to have a dominant leadership role in European and international affairs. Second, that Britons assumed that this leadership function would be primarily expressed through the British Empire and Commonwealth. Finally, although geographically a part of Europe. Britain's position as an island nation, and its imperial history, gave it a unique position as an Atlantic power, which culminated in a self-appointed role of mediator between Europe and the United States in the post-war period. ${ }^{6}$

Throughout the nineteenth century, Britain was the world's pre-eminent international power: Britons dominated international trade and London was the financial capital of the world. The expansion of the British Empire fuelled much of this economic success and the Royal Navy secured it. Victory in the First World War, the dismemberment of Germany's colonial empire and the scuttling of its High Seas Fleet

\footnotetext{
'The idea of a 'special relationship' between Britain and the United States developed in the postwar period, and has been cultivated by Britain. Its continued relevance can be seen in the rhetoric surrounding Barak Obama's state visit to Britain in May 2011, when the American president and British Prime Minister, David Cameron, redefined it as "not just a special relationship, it is an essential relationship." Andrew Porter, "Barack Obama and David Cameron to Rename Special Relationship the 'Essential Relationship'." Daily Telegraph, May 24, 2011.
} 
reinforced the view that the British Empire was a physical manifestation and confirmation of Britain's continuing international pre-eminence. ${ }^{7}$ The 1924 Empire Exhibition at Wembley Park further cemented the perception of a community that stretched around the globe, emphasising the centrality of the Empire to British wealth and prestige. $^{8}$ In six months, twenty-seven million people visited the exhibition. ${ }^{9}$ The Empire was, far more than an expression of British international influence in the nineteenth and early twentieth century: it became a fundamental component of British national identity. The spread of British values throughout the Empire allowed all of its inhabitants to share a common identity based on the British traditions. ${ }^{10}$ Thus out of shared political, legal and educational institutions, a culture of Britishness developed.

The British imperial project at its height also created pax Britannica, affording continental Europe a period of unrivalled stability in the ninety-nine years between Waterloo and Sarajevo, while largely preserving Britain's semi-detachment from the

\footnotetext{
${ }^{7}$ Britain has been labelled by some historians as a precursor to the post-war superpowers of the United States and Soviet Union. Through a physical empire, Britain exercised unparalleled world influence in much the same way that the Americans and Soviets exercised ideological dominance. For examples of this argument see Anthony Clayton. The British Empire as a Superpower, 1919-39 (Athens: University of Georgia Press, 1986). David Egerton, in his book, Warfare State: Britain. 1920-1970 (Cambridge, 2006), also argues that Britain was more of a power than argued in the traditional historiography. Brian McKercher has written about the transition of power, from Great Britain to the United States in a monograph of the same name. B. J. C. McKercher, Transition of Power: Britain's Loss of Global Preeminence to the United States (Cambridge: Cambridge University Press, 2004).

"John M. MacKenzie, "Empire and Metropolitan Cultures," in The Oxford History of the British Empire: The Nineteenth Century, ed. Andrew Porter (Oxford: Oxford University Press, 1999), 283.

"Jonathon Woodham. "Images of Africa and Design at the British Empire Exhibitions between the Wars," Journal of Design History 2, no.10 (1989): 23.

10 Mark Lee. "The Story of Greater Britain: What Lessons Does It Teach?" National Identities 6. no. 2 (2004): 135. Furthermore, some imperial historians suggest that the colonies experimented with political ideas that had been left as theoretical possibilities in Britain. Successful experiments would be exported back to Britain, representing a symbiotic ideological partnership Carl Bridge and Kent Fedorowich, "Mapping the British World," Journal of Imperial and Commonwealth History 31, no. 2 (May 2003): 5. Children's annuals, like the very imperial Chums, propagated and advanced a common set of values and the public school ethos. Patrick Dunae, "Boy's Literature and the Idea of Empire," Victorian Studies 24, no. 1 (1980): 112.
} 
continent. ${ }^{11}$ The Empire also made it possible for Britain to thrive in a world made in its own image and likeness, an exclusively British world, which was perceived as peaceful, enlightened and infinitely superior to the Continental one. ${ }^{12}$ Moreover, the outcome of the Second World War appeared to reaffirm for Britons that the inhabitants of the Commonwealth constituted a progressive and valuable "worldwide community of the 'British race'."13

The Second World War also appeared to have cemented a 'special relationship' between Britain and the United States. This was a matter of pride for Britain, and guarded jealously, but in the post-war period, as Cold War tensions escalated, the United States supported closer European cooperation, so British politicians were forced to pursue a middle course. Winston Churchill's skilful compromise was to suggest that Britain was the centre of three interconnected circles: Europe, the Commonwealth and the Atlantic world and was thus uniquely positioned to act as mediator between the three. Located geographically Europe, Britain's self-perception and identity reflected the belief that it was linked to, but fundamentally apart from the continent. Many Britons agreed with Churchill's statement that Britain should be "with [Europe], but not of them." In the case of the United States, however, there was a sense of familial feeling, akin to that

$"$ Keith Robbins, "The 'British Space': World-Empire-Continent-Nation-Region-Locality: A Historiographical Problem," History Compass 7, no. I (2009): 70. The term "pax Britannica" was used extensively in the mid-twentieth century when describing British foreign and imperial policy at the height of Empire. For example: James Morris, Pax Britannica: Climax of an Empire (New York: Harcourt. Brace \& World, 1968); Albert Henry Imlah, Economic Elements in the Pax Britannica: Studies in British Foreign Trade in the Nineteenth Century (Cambridge, Mass.: Harvard University Press, 1958); Fritz August Voigt, Pax Britannica (London: Constable, 1949); Bo Gabriel Montgomery, Pax Britannica (London: Methuen \& Co. 1928).

${ }^{12}$ Robbins, "The British Space," 72.

${ }^{13}$ Ward, "The End of Empire," 245.

${ }^{14}$ Winston Churchill, Speech to the House of Commons, May 11, 1953, Parliamentary Debates $5^{\text {th }}$ ser., vol. 515 (1953), col. 891 . 
shared by the Commonwealth nations, which was reinforced by the trend of British aristocrats marrying American heiresses during the late nineteenth and early twentieth centuries. ${ }^{15}$ Furthermore, at its core, the United States was a nation built on a foundation of British values: the concept of a British world extended beyond the political designation of 'British Empire' or 'Commonwealth' to include Americans in an ideological 'Greater Britain. ${ }^{16}$ Consequently, many Britons perceived their country as an Atlantic, as well as a European power and saw in the United States vestiges and qualities of 'Britishness' unconfined by physical, geographical boundaries. In fact, this belief persists in the historical imagination, as shown by the American president Barack Obama in his May 2011 address to the British Parliament. According to Obama, the relationship between Britain and the United States was founded not only on:

[a] shared history, [a] shared heritage; ... ties of language and culture; or even the strong partnership between [their] governments. [The British and American] relationship is special because of the values and beliefs that have united [their] people through the ages... [For] [w] hat began on this island would inspire millions ... across the world. ${ }^{17}$

Britain's imperial project had exported its 'values and beliefs,' creating, in the process, a conception that current and former British colonies shared a commitment to the same ideals, uniting them in a community that spanned the globe.

My study of this far-reaching British national identity is heavily influenced by Benedict Anderson's concept of nations as imagined communities. Anderson defines the

\footnotetext{
15 David Cannadine, The Decline and Fall of the British Aristocracy (New Haven, Connecticut: Yale University Press 1990, Reprint, New York: Vintage Editions, 1999), 397.

${ }^{16}$ Duncan Bell, The Idea of Greater Britain: Empire and the Future of World Order, 1860-1900 (Princeton: Princeton University Press, 2007), 271-2. The belief that areas of the world with links to Britain or the United States are part of a larger community is often labelled the 'Anglosphere' or 'English speaking world.'

${ }^{17}$ Barack Obama, "Remarks by the President to Parliament in London, United Kingdom," (speech to Westminster Hall, London, May 25, 2011), accessed October 16, 2011, http://www.whitehouse.gov/thepress-office/2011/05/25/remarks-president-parliament-london-united-kingdom.
} 
nation as "an imagined political community - and imagined as both inherently limited and sovereign." 18 The desire to associate with an exclusive group is the foundation of manufacturing identity. When individuals who lived in Great Britain or the Empire identified themselves as 'British', fundamental to their assertion was the belief that they were members of a wider community. Part of belonging to a group is the exclusion of non-members manifested in the belief that outsiders should be kept separate from the inner workings of the community. Nations are powerful constructs because they are predicated on this idea of exclusive group membership. ${ }^{19}$ In 1962, many people living in Britain believed that continental Europeans constituted these outsiders and that the inhabitants of the Commonwealth, and especially those who lived in the old settler colonies of Australia, Canada and New Zealand, were members of the British community. ${ }^{20}$ The key to the existence of a nation (or of a community or a group), is the belief in its existence by its members.

For Anderson, one of the primary methods of popularising the nation was print capitalism. $^{21}$ The popular press, therefore, is an ideal medium to study the development of national identity. Along with other print publications, newspapers provided a system through which the imagined community of the British nation could be represented. ${ }^{22}$ Since these publications were consumed by millions of readers on a daily basis, they were an effective method of communicating Britishness and thus an important source for this research. 2006), 6 .

${ }^{18}$ Benedict Anderson, Imagined Communities, revised edition (London and New York: Verso,

${ }^{19}$ Anderson, 6-7.

20 Stephen Constantine, "British Emigration to the Empire-Commonwealth since 1880: From Overseas Settlement to Diaspora?" Journal of Imperial and Commonwealth Historv 31, no. 2 (2003): 23.

21 Anderson, 36.

22 Anderson, 25. 
Michael Billig argues that the British press, which exposes its' readers daily to national symbols and expressions of solidarity between Britons, is responsible for building and fostering a sense of British community, or what he calls a 'banal nationalism,' which resides in the British subconscious. ${ }^{23}$ Billig holds that a powerful everyday nationalism can be constructed through the constant daily exposure of people to national symbols, such as the flag and national anthem, and national celebrations and symbolic figures. ${ }^{24}$ The Daily Express's use of Saint George on its masthead, or its frequent use of Britannia and the Union Jack in political cartoons, reinforced popular constructions of British national identity. Common association with such symbols is one method of determining and proclaiming who belongs to the nation. In 1962, for example, the Union Jack still featured on the Australian, Canadian and New Zealand flags. ${ }^{25}$

Members of the Commonwealth community were reminded that they belonged together not only through symbols, but also through shared history and traditions. ${ }^{26}$ They fought side-by-side in the two World Wars, shared a Parliamentary tradition, played football and cricket, and spoke the same language. Billig argues that this sense of commonality allows individuals to believe that while they may travel to unknown geographic regions of 'their' land, they still exert a sense of ownership. ${ }^{27}$ Thus, London was envisioned as an imperial capital, belonging to all subjects of the British Empire, although the image hid a more complex relationship between the metropole and the periphery. For example, the post-war period saw an increase in colonial immigration to

${ }^{23}$ Michael Billig, Banal Nationalism (London: Sage Books. 1995), 38.

${ }^{24}$ Billig, 45.

${ }^{25}$ In 2011 both the Australian and New Zealand national flags still incorporate in their design the Union flag, as do the Canadian provinces of Ontario. Manitoba and British Columbia.

26 Billig, 71.

${ }^{27}$ Billig, 74. 
Britain, and new arrivals often found that they were not welcomed as imperial cousins. ${ }^{28}$ Nonetheless, the idea of an imperial family persisted in the British imagination through a myriad of small reminders that the Empire was central to Britain's identity. ${ }^{29}$ Billig believes that the focus on more obvious extremist nationalism has caused many scholars to discount the less flamboyant variant, leading to an underestimation of its force and significance in modern society. ${ }^{30}$ Yet nations continue to form a foundation of identity, and nationalism remains a potent cultural force. Correcting this oversight, as Billig has argued, will allow for a more nuanced study of nationalism and national identity, regardless of whether communities are based on ethnic, political or cultural ties.

Two types of nationalism are widely discussed in the literature: ethnic or cultural nationalism, and political or civic nationalism. In the case of British national identity, this dichotomy is problematic because it is difficult to strictly delineate the two concepts. Bernard Yack argues that all modern political communities are culturally based because political organization is founded not only on the voluntary consent of citizens, but also on shared memory and experience. ${ }^{31}$ Those who try to separate cultural and political nationhood are therefore deluding themselves, since the idea of a civic nation is, in itself, a cultural inheritance. ${ }^{32}$ Yack contends that shared political institutions and values create a shared culture, as in the case of the British Empire; thus Britons were not related by

\footnotetext{
${ }^{28}$ Marcia E Sutherland, "African Caribbean Immigrants in the United Kingdom: The Legacy of Racial Disadvantages." Caribbean Quarterly 52 (2006): 26.

${ }^{29}$ One interesting aspect of the far reaching affects of the British Empire in everyday life can be seen in food consumed in former colonies such as Canada. Many of the sweets and confections currently sold in Canada come from Britain, including Smarties and Aero, which are not available in the United States. David Carr, Canctymaking in Canada (Toronto: Dundurn, 2004), 65.

${ }^{30}$ Billig, 43.

${ }^{31}$ Bernard Yack, "The Myth of the Civic Nation," Critical Review 10, no. 2 (Spring 1996): 196.

${ }^{32}$ Yack, 203.
} 
ethnic ties, but shared the idea of a common culture which transcended the geographic boundaries of Great Britain.

The role of nationalism and national identity in tracing support for European integration is controversial. Some scholars argue that a strong national identity is incompatible with European integration, as it crowds out any sense of a European identity or concept of European citizenship. Other scholars, however, claim that a strong national identity makes a population more likely to support the European Union. ${ }^{33}$ But what is perhaps most important in determining support for European integration is the process by which national identity has been manufactured. Although there is much disagreement over the particular substance of British national identity, most scholars would agree that it has historically been constructed to emphasize the uniqueness of the British people as compared to those of continental Europe. ${ }^{34}$ Many Britons believed that they had infinitely more in common with far away inhabitants of the Empire or 'Greater Britain', than with continental Europeans. In the eighteenth and nineteenth centuries, continental Europe had been home to Catholicism and absolute monarchy, revolution and reaction, and in the twentieth century, the Continent was the breeding ground of communism and fascism. In contrast, Britain and its Empire, had offered refuge to those fleeing political and religious persecution, and who perceived the British home and imperial rule as

${ }^{33}$ Dirk Jacobs and Robert Maier, "European Identity: Construct, Fact and Fiction," in $A$ United Europe: The Quest for a Multifaceted Identity, edited by Marja Gastelaars and Arie de Ruijter (Maastricht [Netherlands]: Shaker Publishing, 1998), 13-34. For the former argument see Sean Carrey, "Undivided Loyalties: Is National Identity an Obstacle to European Integration?" European Union Politics 3, no. 4 (2002): 387-413; and Richard Haesly, "Euroskeptics, Europhiles and Instrumental Europeans: European Attachment in Scotland and Wales," European Union Politics 2, no. 1 (2001): 81-102. For the latter argument see Liesbet Hooghe and Gary Marks, "Does Identity or Economic Rational Drive Public Opinion on European Integration?" PS: Political Science and Politics 37, no. 3 (2004): 415-20. 32 (2006): 320 .

${ }^{34}$ Oliver Daddow, "Euroscepticism and the Discipline of History," Review of International Studies 
beneficent. $^{35}$ It followed, therefore, that if the British people defined themselves against the 'other' of Europe, any attempt to integrate with the Continent ran contrary to some two centuries of British identity building, raising questions about its very survival. These questions crystallised in 1962 when the Commonwealth leaders met to discuss British participation in European integration. The application to join the EEC, and the popular belief that membership would threaten the Commonwealth, led to fears that British identity would be sacrificed to Europe.

The printed expression of such political and social concerns in the press allowed for public debate through the medium of popular culture. Popular culture is often defined by its association with the people, but the relationship is complex. The press claims to be the voice of the people, while also seeking to influence popular culture. The popular press thus has a dual role as both a medium of resistance and of domination. ${ }^{36}$ Negotiations of power take place between the elites and the general population through the media because of its concurrent reflection and manipulation of public opinion. As a result, the media is particularly suited to influence nationalistic discourse. In 1962, newspapers were still the primary source of news for most Britons. ${ }^{37}$ The mundane texts and images of the press created and reinforced constructions of national identity, framed in rhetoric, vocabulary, and visual representation. The nationalistic messages of the press were subtle

\footnotetext{
${ }^{35}$ Hugh Gaitskell, "In a Speech to the 1962 Annual Conference of the Labour Party," Address to the Annual Labour Party Conference, October 3, 1962 in Britain and the Common Market (London: Labour. 1962), 10.

${ }^{36}$ Martin Conboy, The Press and Popular Culture (London: Sage Publications, 2002), 17.

${ }^{37}$ In 1962, 16.6 million homes in Britain had a television. Broadcaster's Audience Research Board, accessed April 17, 2010, http://www.barb.co.uk/facts/tvOwnershipPrivate. In 1961, national morning newspaper circulation was 15.834 million, national evening newspaper circulation was 2.203 million and provincial newspaper circulation was 8.5 million. Sunday newspaper circulation was 24.536 million. W. Hartley Shawcross, Royal Commission on the press 1961-62. Report. 1961-62, XX1.1, 12-3. Newspapers were accessible to all segments of the British population whereas many working class families were unable to afford a television.
} 
with their own tropes as well as textual and visual imagery. I explore how these messages were formed through the interplay of text and images, analysing how this representation of nationalism allowed for public debate through the medium of popular printed material in the 1960s.

While Juergen Habermas claimed that the twentieth century saw a decline in the culture of political engagement in the popular press, British newspapers in the twentieth century, in fact, grew to exert unprecedented political power and influence. ${ }^{38}$ Indeed, the government was concerned enough about the political influence, and increasing monopolisation of the press, to establish two Royal Commissions on the press in less than twenty years. $^{39}$ The British press continues to play an important role in public discourse, particularly with respect to European integration. For the most part, it also persists to frame its discussion of European integration from the perspective of national identity, and its commentary and analysis frequently assume that Britain is not European. ${ }^{40}$ By

${ }^{3 *}$ Much of this power was predicated on W.T. Stead's theories of government by journalism. Stead believed that the press could truly represent all of the people, and that the press was a truer and nore relevant form of government than Parliament, which was often guilty of ignoring public opinion in the years between elections. W.T. Stead, "Government by Journalism," Contemporary Review, vol. 49 (1886): 653-74; Stephen Koss. The Rise and Fall of the Political Press in Britain: Twentieth Century (Chapel Hill: University of North Carolina Press, 1984), 2.

${ }^{39}$ The first Royal Commission on the Press was appointed in 1947, and the second in 1961. The Royal Commission on the Press of 1961-2 was published in September 1962, during the Commonwealth Conference. Its stated purpose was to "examine the economic and financial factors affecting the production and sale of newspapers, magazines and other periodicals... to consider whether these factors tend to diminish the diversity of ownership and control... having regard to the importance, in the public interest, of the accurate presentation of news and the free expression of opinion." W. Hartley Shawcross, Royal Commission on the press 1961-62. Report, 1961-62, XXI.1, 9. See also William David Ross, Roval Commission on the press 1947-49. Report, 1948-49, XX.1.

40 "Pourquoi le Royaume-Uni est-il eurosceptique?" EurActive Network, accessed April 6, 2010. http:/www.euractiv.com/fr/affaires-publiques/royaume-uni-eurosceptique/article-178328. According to the Economist columnist 'Charlemagne', the majority of British newspapers receive their European Union news from Open Europe, which he calls "a small, but assiduous Eurosceptic campaign group." Charlemagne, "Spoon feeding Lazy Journalists: Open Europe: the Eurosceptic group that controls British coverage of the EU," Economist, March 31, 2010. For an academic study of this phenomena, see Oliver Daddow, "Euroscepticism and the Culture of the Discipline of History," Review of International Studies 32, 2 (2006): 316. 
probing the political debates which surrounded the 1962 Commonwealth Conference, I have sought to explore an early instance of Eurosceptism and to explain its continuing and enduring political relevance.

This work begins by contextualising post-war British national identity and the press, thereby establishing the framework that will be used throughout the thesis. The second chapter examines newspaper coverage of the Commonwealth Conference in early September, 1962. I have studied newspaper articles, editorials, letters to the editor and political cartoons in order to determine how the Commonwealth and Europe were portrayed, focusing on nationalistic imagery and language. I am particularly interested in the daily reinforcement of national identity through the repetitive use of phrases and images which coloured the public discourse and worked to reinforce a shared sense of community. The political ramifications of the Commonwealth Conference form the basis of the third chapter, which looks at each of the major annual political party conferences in September and October of 1962. During these conferences, the subtle nationalistic imagery and language became overt, as politicians and newspaper editors sought to appeal to Britons' national pride and loyalty to the Commonwealth in their discussion of European integration. British participation in the Common Market had become increasingly politicised, and culminated in the Prime Minister's explicit use of the term 'national identity' in his speech to Conservative Party delegates on the government's European policy. ${ }^{41}$ As part of the debate over British membership, the fourth chapter focuses on French concerns over the British application expressed through the pages of Le Monde and Le Figaro. These leading French newspapers showcase the continental

\footnotetext{
41 Harold Macmillan, "Speech to the Delegates," 81st Annual Conservative Party Conference, Llandudno, October 13, 1962, in The Times, October 15, 1962.
} 
European debate over whether Britain was a European or an imperial country. They demonstrate that continental Europeans appreciated that the Commonwealth was a key element of British national identity and were apprehensive that the continued importance of the Commonwealth tied Britain to its former colonies, and would likely seriously impeded Britain's full participation in the Common Market. The analysis of the French press provides context for the British debates over national identity, as well as helping to explain why the British application was ultimately rejected.

In 2010, almost 40 years after its admission to the EEC in 1973, Britain's attitude towards European integration remains ambivalent. ${ }^{42}$ Much of the British press is staunchly Eurosceptic, displaying open hostility towards Europe. ${ }^{43}$ The current Euroscepticism of the press echoes the debates of the early 1960s when Britain first began its move towards Europe. The historiography of post-war British involvement with Europe, however, is largely silent on the role of the press in informing public opinion about Britain's application to the EEC. ${ }^{44}$ George Wilkes and Dominic Wring do offer a brief overview of the changing attitudes of the press, claiming that prior to 1961 the British press was, for the most part, enthusiastic about membership in the EEC, but that support declined after the Conservative Government of Harold Macmillan made its

42 The Conservative Party's official platform attacks the Lisbon Treaty as threatening British sovereignty and bemoans the "steady and unaccountable intrusion of the European Union into almost every aspect of our lives." "Where We Stand: Europe." Conservative Party, accessed April 5, 2010, http://www.conservatives.com/Policy/Where_we_stand/Europe.aspx.

${ }^{43}$ As an example, the (Daily) Express ran a story on April 3, 2010 claiming that membership in the EU and its intrusions into British life are depriving young Britons of opportunities. "A Girl Who Can't Study to be a GP Because of EU Invasion," Express, April 3, 2010.

${ }^{44}$ For full coverage of the historiography of Britain's relationship with the EEC during this period see Oliver Daddow, Britain and Europe since 1945: Historiographical Perspectives on Integration (Manchester: Manchester University Press, 2004). Beaverbrook and the Daily Express's disdain for the EEC are briefly mentioned, but there exists no in depth investigation into the press coverage of Britain's applications to join the EEC. 
application. In fact, Wilkes and Wring argue that by the time of the Commonwealth Prime Ministers Conference, support for British membership had waned considerably. ${ }^{45}$ Other scholars examining Britain's post-war relationship with Europe present similar conclusions. ${ }^{46}$ None, however, offers any explanation for the change or shows how the press influenced public opinion. ${ }^{47}$ My thesis addresses these questions through an in depth analysis of several major British newspapers. Discussions over the Commonwealth, European integration and British national identity dominated the columns of the press in September 1962, often featuring repeatedly in news articles as well as editorials and cartoons. Given the extensive engagement of the press in these issues, I have chosen to focus exclusively on content, including the language and imagery, related directly to the Commonwealth Conference. ${ }^{48}$

In the early $1960 \mathrm{~s}$, class was still a defining social and structural feature of British society. Accordingly, I have selected for analysis a cross-section of popular daily newspapers which targeted both working class and the middle class audiences with a combined circulation of $10,781,000 .^{49}$ I have also tried to ensure that my sources are representative of both the democratic left and the democratic right in British politics. The working class press is represented by the left leaning Daily Mirror and Daily Herald

${ }^{45}$ George Wilkes and Dominic Wring. "The British Press and European Integration, 1948-1996." in Britain For and Against Europe: British Politics and the Question of European Integration, eds. David Baker and David Seawright (Oxford: Clarendon Press, 1998), 185-205.

46 See for example David Gowland and Arthur Turner, Reluctant Europeans: Britain and European Integration, 1945-1998 (London: Longman, 2000), 122.

${ }_{47}$ In 1976, James Spence suggested that the popular press had a substantial role in rallying popular support for membership in the EEC, but newer studies have not addressed this question. James Spence, "Movements in the Public Mood, 1961-1975," in Britain Into Europe: Public Opinion and the E.E.C.. 1961-1975, eds. Roger Jowell, and Gerald Hoinville (London: Social and Planning Research, 1976), 22.

${ }^{48}$ For the most part, I have disregarded articles that focus on the domestic economic impact of the Common Market and Franco-German relations.

${ }^{49}$ Shawcross, Royal Commission on the Press, 12. 
newspapers, while the Daily Express was a widely circulated working class Tory newspaper. All three newspapers were characterised by strong editorial control that ensured a consistent tone and message with respect to the Commonwealth and European integration. $^{50}$ I have deliberately chosen the three most influential organs of the working class press during the mid-twentieth century, although there were other sensationalistic dailies. $^{51}$

A leftist tabloid that targeted the working class, the Daily Mirror was Britain's most widely read newspaper in the post-war period, with a circulation of $4,561,000 .^{52}$ Unlike the other two mass circulation dailies in this study, the Daily Mirror was a sensationalistic newspaper without an overt political agenda, which provided an independent working class discussion of European integration and the future of the Commonwealth. The Daily Herald was also a leftist newspaper that had enjoyed widespread circulation in the interwar period, although its circulation had been reduced to $1,394,000$ by $1961 .^{53}$ Owned partially by the Trades Union Congress, the newspaper's relationship with the Labour Party had declined in importance by the 1960 s, but the Daily Herald's editorial board continued to be sympathetic to Labour policies. ${ }^{54}$ The Daily Herald's coverage of the Commonwealth Conference focused extensively on the Labour

\footnotetext{
${ }^{50}$ The Daily Mirror group was controlled by Cecil King and the Daily Express was the flagship of Lord Beaverbrook's media empire. See Piers Brendon, The Life and Death of the Press Barons (New York:Atheneum., 1982).

${ }^{51}$ Other mass circulation dailies included in the Royal Commission on the Press's circulation numbers are the Daily Mail, the Daily Sketch, the Daily Worker, the New Daily and the News Chronicle. Shawcross, Royal Commission on the Press, 12.

52 Shawcross, Royal Commission on the Press, 12. By the mid-1960s the Daily Mirror sold over five million copies a day. Charles Wintour, The Rise and Fall of Fleet Street (London: Hutchinson, 1989), 142.

${ }^{53}$ Shawcross, Royal Commission on the Press, 12. In the 1930s, the Daily Herald was the Daily Express's leftist rival, with a daily circulation of 2 million to the Express's 2.2 million.

54 In 1960, the Trades Union Congress relinquished control over editorial policy, but policies remained consistent until the demise of the Daily Herald in 1964. Huw Richards, "The Daily Herald: 1912-1964," History Today 31, no. 12 (1981): 15, 16.
} 
Party's changing policy with regards to membership in the EEC. ${ }^{55}$ The Daily Herald situated the popular debates about Empire and Europe in the wider political discussions of the 1950s and 1960s. The Daily Express was the most widely read conservative newspaper in the 1960 s with a total circulation of $4,328,000 .^{56}$ It strongly reflected the politics of its proprietor, Lord Beaverbrook, so although its outlook and tone was conservative, the paper had a contentious relationship with the Conservative Party. ${ }^{57}$ The paper provides an interesting perspective on discussions of Empire and Europe, since Lord Beaverbrook was a Canadian by birth and a staunch supporter of the British Empire.

The middle class is primarily represented by The Times and the Guardian. I chose The Times because it was widely believed to be the most authoritative British newspaper and was read by both the middle class and the elites. ${ }^{58}$ The Guardian was a centre left middle class paper with a circulation of 245,000 in $1961 .^{59}$ Like The Times, the Guardian was a quality newspaper, dependent on its reputation rather than sensationalist journalism to attract readers. ${ }^{60}$ Unlike the other newspapers, the Guardian allowed for more journalistic freedom, which resulted in differing opinion amongst its

ss After months of back and forth, the Labour Party announced its opposition to the negotiated terms of entry at the beginning of September 1962. coinciding with the Commonwealth Conference.

${ }^{56}$ Shawcross, Royal Commission on the Press, 12.

${ }^{57}$ Although Lord Beaverbrook had officially relinquished control of the Daily Express to his son, he remained in complete control of the newspaper until his death in 1963. Thomas, 34, 37. D. George Boyce, 'Aitken, William Maxwell, first Baron Beaverbrook (1879-1964)', Oxford Dictionary of National Biography, Oxford University Press, 2004; online edn, Jan 2011, accessed 14 May 2011, http://www.oxforddnb.com.proxy.library.carleton.ca/view/article/30358.

58 The Times had a circulation of 253,000. Shawcross, Royal Commission on the Press, 12. Characterized by columns of text with no large headlines or illustrations. The Times did not start printing news on its front page until 1966. Although the political outlook of the editorial board changed, depending on the politics of both the editor and proprietor, The Times was a major source of political news throughout the mid-twentieth century for the middle class, and enjoyed a reputation and influence belied by its circulation figures.

${ }^{59}$ Shawcross, Royal Commission on the Press, 12.

${ }^{60}$ Ross, Royal Commission on the Press, 26. 
contributors. The Times and the Guardian, therefore, provide insight into the middle class debates about the Empire and Europe during the post-war period.

The French newspapers provide a further point of comparison. Le Monde and Le Figaro representing, respectively, a centre-left and a centre-right perspective, afford insight into how two well regarded French newspapers portrayed the British application, concerns over the plight of the Commonwealth and the predicament of British post-war national identity. In 1960 , The Times implied that continental Europeans believed that Britain had to choose between Commonwealth and EEC identities. ${ }^{61}$ The tone, language and images (including political cartoons) used by Le Monde and Le Figaro to describe and comment upon the British application, and Commonwealth Prime Ministers conference, allow me to gauge the degree to which Britain's historic imperial links, at least through the lenses of these two papers, were seen as a barrier to membership in the EEC.

Political cartoons have proven to be among the most fruitful sources of nationalistic imagery. Cartoons, however, like other works of satire, are based on exaggeration and, as such, they cannot be read literally. ${ }^{62}$ They are not a direct representation of either the artists' views or public opinion, although cartoons do provide insight into both political and popular discourse. Political cartoons are, by their very nature, specific. Thomas Milton Kemnitz, one of the first historians to examine the use of political cartoons as an historical source, has observed that their success is dependent

61 "Commonwealth Or Europe?: Choice Oversimplified For Britain," The Times, September 1, 1960. The Times references comments made by the Austrian Foreign Minister, Dr. Kreisky although Austria itself did not join the European Union until 1995.

62 Frank Palmeri, "The Cartoon: The Image as Critique," in History Beyond the Text, eds. Sarah Barber and Corinna M. Peniston-Bird (New York: Routledge, 2009), 32. 
on the viewer's ability to recognise the characters, subjects, and events that have been depicted. $^{63}$ If a viewer cannot access the material, the cartoonist's message will not be communicated. As such, cartoons are a tool for discerning membership in the national community: all Britons should comprehend the references made in a Low, Cummings or Franklin cartoon. The images themselves, therefore, become part of the nationalistic language. The use of Britannia and the charge of the Light Brigade, or of politicians such as Macmillan and Gaitskell, assume that readers will immediately recognise the figures and context. The cartoons reinforce and reiterate the qualities of a British identity; those who cannot access the cartoons are wanting as full members of the British community.

Cartoons often serve as a sort of foil to news articles. Unlike a news article, their message is implicit and highly interpretive. As a result, the cartoonist's message can be misunderstood. ${ }^{64}$ This misunderstanding, however, makes the cartoon more powerful as the audience must fully engage with the cartoon in order to construct meaning. Cumming's portrayal of de Gaulle and Adenauer as ancient Romans may have been a reference to Caesar's conquest of Britain by $43 \mathrm{BC}$ and the need to avoid association with the EEC, a latter day manifestation of the Roman Imperium. ${ }^{65}$ The reference, however, could also be an intimation of decadence and weakness as de Gaulle and Adenauer are often portrayed lounging, eating and drinking at a convivium. Nonetheless, the different interpretation of the Roman reference does not affect the cartoon's message: de Gaulle

${ }^{63}$ Thomas Milton Kemnitz. "The Cartoon as a Historical Source," The Historian and the Arts 4. no. 1 (Summer, 1973): 82. Kemnitz's work was rapidly followed by the publication of two other articles that also examined the use of cartoons as sources: Colin Seymour-Ure, "How Special Are Cartoonists?" Twentieth Century Studies 13. no. 14 (1975): 6-21; Abu Abraham, "Anatomy of the Political Cartoon," Indian Horizons 23, no. 1 (1974): 19-27.

${ }^{64}$ Colin Seymour-Ure, "How Special Are Cartoonists?" 19.

${ }^{65}$ See for example Guardian, September 13, 1962 where de Gaulle and Adenauer are portrayed dressed as Romans. It was reprinted in Le Monde on September 19, 1962. 
and Adenauer are clearly identified with Rome, an invading foreign power, which Britons must avoid in order to preserve their unique and shared culture.

Scholarship exploring the birth of a common British culture did not exist until 1992. ${ }^{66}$ Although there were earlier works on English, Scottish, Irish and Welsh identities, it was not until the publication of Linda Colley's Britons: Forging the Nation, 1707-1837 that a concerted attempt was made to trace the origins of Britishness. Britons has proven difficult for historians working on British nationalism to ignore. Colley believed that British identity developed in response to conflicts with Europe, and in particular France. According to Colley, the 'popish slavery' said to exist in Catholic Europe contrasted very unfavourably with the 'British liberty' associated with Protestantism. ${ }^{67}$ The British "came to define themselves as a single people not because of any political or cultural consensus at home, but rather in reaction to the Other beyond their shores." ${ }^{\text {, } 88}$ In the process, a British identity developed, based on shared experiences and the institutions of the Protestant faith. When religious fervour faded, the influence of Protestant ideas continued, being visible even in the language used during the Second World War. ${ }^{69}$

Although Colley uses the idea of empire, it is not central to her concept of Britishness. Some historians argue that Colley did not place sufficient emphasis on the role of empire in the development of a British identity and her concentration on religion

${ }^{60}$ Raphael Samuel's collection Patriotism: The Making and Ummaking of British Identity, published in 1989, heralded the beginning of a new area of study. This collection's main contribution to the field, however, was the differentiation between 'Britishness' and 'Englishness'. Raphael Samuel, ed., Patriotism: The Making and Unmaking of British National Identity (London: Routledge, 1989).

${ }^{67}$ Linda Colley, Britons: Forging the Nation, 1707-1837, revised edition (New Haven: Yale University Press, 2009), xxi. One of the major criticisms of Colley's work is that she ignores the existence of other European Protestants.

${ }^{68}$ Colley, Britons, 6.

${ }^{69}$ Colley, Britons, 29. 
as the key defining aspect of Britishness may have caused her to overlook empire as a more unifying force. During the nineteenth century, the Empire and Britain's economic hegemony dominated discussions of Britishness. Murray Pittock has stated that "the Empire was the key to British unity." ${ }^{70}$ Indeed, David Armitage has argued that being British did not mean that one necessarily lived in the British Isles; rather it meant that one was part of the British Empire. Britain's maritime power, commercial economy, parliamentary democracy and its Protestantism were the key elements in both conceptions of the British Empire and British identity: my work explores the extent to which faith in the Empire continued to form a cornerstone of British national identity in the post-war period.

One of the crucial attributes of the British Empire was the association of the colonists with a British identity. British migrants to the colonies not only became Canadian or Australian, they also maintained a British identity, successfully exporting the concept of a British community to the colonies and creating a British world. In forming the settler colonies of Canada, Australia, and later New Zealand and Rhodesia, Britain provided not only the institutions and laws of the new community, but also its immigrants and its culture. The original inhabitants were quickly outnumbered by the new arrivals, except in the case of Rhodesia. Historians have successfully argued that these colonies were not plantations or trading bases, but were intended to be transplantations of British society. While many colonists hoped to leave the problems of British society in Europe, such as the class system, they were still determined to recreate a distinctly British

\footnotetext{
${ }^{70}$ Murray Pittock, Inventing and Resisting Britain: Cultural Identities in Britain and Ireland. 1685-1789 (New York: St. Martin's Press, 1997), 135.
} 
civilisation in these new lands. ${ }^{71}$ Settlers maintained an economic and a political dependence on Britain, as well as maintaining social relationships with family and friends that were left behind. ${ }^{72}$ The resulting familial, religious, educational, and professional associations led to the development of British networks that ensured Britons throughout the Empire shared a similar language, cultural experience, and values. ${ }^{73}$ Britons were all $^{\circ}$ members of one civilisation and the concept of a British world was central to their identity, whether they lived in Great Britain or were scattered throughout its Empire.

The centrality of the Empire to British identity is echoed by Stuart Ward in his examination of changes to British identity. The Second World War left Britain in economic and social disarray, which combined with the granting of independence to former colonies led to a shift in colonial and foreign affairs. According to Ward, "only rarely is this connection between the loss of the Empire abroad and the demise of Britishness at home developed beyond a crude caricature." ${ }^{74}$ Some scholars have argued that during the high period of the Empire, the place of the 'other' in British national identity shifted from Europe to the colonial. ${ }^{75}$ For Ward, however, it is not the 'Otherness' of Empire but the 'Sameness' that is central to understanding British identity.

${ }^{71}$ Philip Buckner, Canada and the British World: Culture. Migration and Identity (Vancouver, UBC Press, 2006). 7-8.

72. Carl Bridge and Kent Fedorowich, "Mapping the British World," Journal of Imperial and Commonwealth History, 31, no. 2 (2003): 6.

${ }^{73}$ Mark Lee, "The Story of Greater Britain: What Lessons Does It Teach?" National Identities 6 , no. 2 (2004): 135 . Furthermore, some imperial historians suggest that the colonies "often put into practice what the reformers in Britain itself merely talked about." Stuart Ward, Australia and the British Embrace: The Demise of the Imperial Ideal (Carlton South: Melbourne University Press, 2001), 2; Bridge and Fedorowich, 5.

${ }^{74}$ Stuart Ward, "The End of Empire and the Fate of Britishness," in History. Nationhood and the Question of Britain, ed. Helen Brocklehurst and Robert Phillips (New York: Palgrave MacMillan, 2004), 243.

${ }^{75}$ Linda Colley, "British and Otherness: An Argument," The Journal of British Studies 31, no. 4 (1992): 309-329; Richard Weight, Patriots: National Identity in Britain 1940-2000 (London: Macmillan, 2002). 
While he does not disagree with the inherent otherness of India and Africa, for Ward, the relationship between the 'Mother Country' and Britain's white settler communities defined Imperial identity: the citizens of settler colonies were Britons, and "metropolitan Britons could project an expansive view of the national self around the globe."76

Historians of British national identity have argued that Britain's island status not only affected the development of the Empire, but it also fundamentally shaped British national identity. Britons were characterized as an island-people and Britishness developed with a peculiar maritime focus. ${ }^{77}$ For ordinary Britons the sea not only insulated Britain from Europe, but it was also the method by which Britishness was exported throughout the world, creating a community of Britons independent of the British Isles. Faith in this British community, while challenged by the events of the twentieth century, was too well ingrained within the subconscious of the nation to have dissipated by the post-war period: the physical reality of the Empire faded, but its ideological and cultural importance remained.

The role of the Empire in twentieth century British historiography is problematic. Most historians accept its centrality in the nineteenth century, but argue that its importance faded after the First World War. ${ }^{78}$ According to the standard narrative,

${ }^{76}$ Ward, "The End of Empire," 245.

${ }^{77}$ Ken Lunn and Ann Day, "Britain as Island: National Identity and the Sea." in History, Nationhood and the Question of Britain, ed. Helen Brocklehurst and Phillips (New York: Palgrave MacMillan, 2004), 126.

${ }^{78}$ There are also some historians, such as Bernard Porter, who argue that Empire never played an important role in the lives of most Britons. There was no national imperial identity: but rather a multiplicity of identities that melded together, varying according to class and location. Furthermore, the lack of national imperial identity was deliberate. Nationalism is most often taught through the school system through history, literature and civics. British schools deliberately followed a classical curriculun, focused on Greek and Latin language rather than English literature. This focus reflects the suspicion of nationalism that characterized the British ruling class. Nationalism was "anachronistic and potentially dangerous" for the working class. Elite suspicions of the working class and the danger inherent in any mass mobilisation meant that there was no British national identity. Porter pointed to the lack of mass 
Britain dissolved its Empire peacefully, especially in comparison to France's bloody experience. The loss of the Empire is said to have had little effect on British life since Britons were more concerned with rebuilding their country after the war than worrying about the loss of territory in Asia or Africa. ${ }^{79}$ Furthermore, the Labour Government introduced far reaching social reforms that greatly and positively impacted everyday life in Britain. Post-war Britain, in short, simply lost interest in the Empire. But recent work has begun to question this assumption, asking how a society that had been fundamentally tied to an imperial identity could simply 'forget' the Empire.

This interest in the continuing importance of imperial ideas in British culture presents an opportunity to probe the meaning of national identity in twentieth century Britain, as well as addressing a flaw in the standard historiographical narrative. The British Empire was the most powerful political organisation of the nineteenth century; surely it could not have simply faded into oblivion without affecting the lives of its inhabitants? Bernard Porter and David Cannadine have begun to question how and why Britain seemed so unaffected by the loss of its Empire. ${ }^{80}$ Both argue that the loss of the Empire must have affected Britons sense of themselves and their nation. After all, as Porter stated, "nations do not suddenly lose Empires without their leaving a mark." 81

protest over the dissolution of the Empire is symptomatic of a fundamental antipathy towards the Empire. If the Empire had formed the basis of British national identity popular reaction would not have been so anaemic. Bernard Porter. The Lion's Share: A Short History of British Imperialism (Harlow: Longman, 1996), 261, 264.

${ }^{79}$ David Cannadine, "Apocalypse When? British Politicians and British 'Decline' in the Twentieth Century," in Understanding Decline: Perceptions and Realities of British Economic Performance, eds. Peter Clarke and Clive Trebilcock (Cambridge: Cambridge University Press, 1997), 261-2; D. George Boyce, Decolonisation and the British Empire, 1775-1997 (London: Macmillan, 1999), 270; Bernard Porter, The Lion's Share: A Short History of British Imperialism (Harlow: Longman, 1996), 347.

${ }^{80}$ David Cannadine, Ornamentalism: How the British Saw Their Empire (Oxford: Oxford University Press, 2001), 154; Bernard Porter, "The Empire Strikes Back," History Today 46, no. 9 (1996). 11-3.

\footnotetext{
${ }^{81}$ Porter, "The Empire Strikes Back," 11.
} 
Historians have also begun to question whether the lack of protest over decolonisation during the post-war period actually indicated a lack of interest in empire. The preoccupation with the British Empire's comparatively peaceful transition to the Commonwealth of Nations has arguably obscured a continuing imperial culture in Britain. Imperial themes still dominated popular culture, as demonstrated by Kathryn Castle's study of children's literature, Jeffrey Richard's work on cinema and Michael Paris's work on images of war in popular culture. ${ }^{82}$ Cultural historians have been the initiators of investigations into the continuing relevance of the Empire in British society. One of the most interesting approaches has focused on colonial immigration and its role in post-war British culture. ${ }^{83}$ These historians have concluded that Britain continued to be influenced culturally by the Empire, even if its political and economic importance disappeared during the twentieth century. My research builds on this foundation as it seeks to explore popular understandings of Empire during this period of transition.

Britain emerged from the Second World War victorious, but at a tremendous price. Britain was left with a battered economy, a dilapidated infrastructure and an empty treasury. It could no longer afford the costs associated with an Empire that stretched across six continents. Furthermore, the Dominion colonies, those granted political independence during the late nineteenth and early twentieth century, had fought in the

82 Kathryn Castle. "Imperial Legacies, New Frontiers: Children's Popular Literature and the Demise of Empire," in British Culture and the End of Empire, ed. Stuart Ward (Manchester: Manchester University Press, 2001), 145-62; Jeffrey Richard, Films and British National Identity: From Dickens to Dad's Arny (Manchester: Manchester University Press, 1997), especially "British Imperial Heroes" and "The Black Man as Hero," 31-81; Michael Paris, Warrior Nation: Images of War in British Popular Culture, 1850-2000 (London: Reaktion, 2000).

${ }^{83}$ Laura Tabili, "A Homogenous Society? Britain's Internal 'Others,' 1800-Present" in At Home with the Empire: Metropolitan Culture and the Imperial World, eds. Catherine Hall and Sonya Rose (Cambridge: Cambridge University Press, 2007), 53-76; Kathleen Paul, "Communities of Britishness: Migration in the Last Gasp of Empire," in British Culture and the End of Empire, ed. Stuart Ward (Manchester: Manchester University Press, 2001), 180-99. 
war under their own flags as independent countries, and were no longer willing to follow Britain's lead in global affairs. Many of the colonies which Britain still possessed were clamouring for political independence. With financial and political pressures increasing, Britain began the final dissolution of the Empire during the post-war period.

The post-war also saw the beginnings of European integration. Organisations set up to assist in the reconstruction of Western Europe, such as the United Nations Relief and Rehabilitation Association (UNRRA) and the Organisation for European Economic Co-operation (OEEC), laid much of the ground work for the eventual establishment of the EEC. ${ }^{84}$ Britain was a participant in the OEEC and successfully lobbied to ensure that the organisation was intergovernmental in character rather than supranational. ${ }^{85}$ This distinction meant that Britain was not required to cede sovereignty to a higher authority: the OEEC was an organisation that facilitated co-operation, but did not force unification.

While this compromise satisfied Britain, American pressure for European unity continued throughout the $1950 \mathrm{~s}$. British sovereignty was willingly compromised in the interest of European defence, in the Brussels Treaty and the foundation of the North Atlantic Treaty Organisation (NATO). NATO membership also appealed since it satisfied Britain's decided preference for an Atlantic, rather than solely European solution

\footnotetext{
${ }^{84}$ The OEEC was, in fact, the body responsible for the administration of American funds in Europe through the Marshall Plan.

${ }^{85}$ European economic co-operation was a built in condition to American financial aid during the 1940s and 50s, as the Americans hoped that a more unified Western Europe would form a bulwark against communist expansion. The OEEC was, in fact, the body responsible for the administration of American funds in Europe through the Marshall Plan. Alex May, Britsin and Europe Since 1945 (London: Longman, 1998), 14.
} 
to the threat of communist aggression. ${ }^{86}$ The emphasis on the Atlantic approach represented the continuation of British policy into the post-war period. The potential instability of Europe could not be ignored, but NATO allowed Britain to continue to focus on concerns that lay outside of the continent.

Britain's desire to remain at arms' length from continental Europe was evident as Europeans met to discuss the possibility of integration. The idea of European integration was not opposed by Britain, whose own post war recovery needed the political and economic stability that European integration would bring to France and Germany. However, Britons did question the degree of involvement necessary to ensure that the European experiment was successful. ${ }^{87}$ British participation in The Hague Conference, a forum for discussions related to European political cooperation, was highly controversial, reflecting the tension in society over Britain's involvement in European affairs. ${ }^{88}$ Questions over Britain's role continued as France, Germany and the Benelux countries moved towards further economic and political integration in the $1950 \mathrm{~s} .{ }^{89}$ Although Britain was invited to attend the negotiations, it ultimately decided neither to join the European Coal and Steel Community (ECSC) in 1951 nor to sign the Treaties of Rome in 1958 which established both the European Atomic Energy Community (Euratom) and the

\footnotetext{
${ }^{86}$ Britain's preference for NATO over European organizations is a common theme in the literature. See for example Miriam Camp, "Missing the Boat at Messina and Other Times," in From Reconstruction to Integration: Britain and Europe Since 1945, eds. Brian Brivati and Harriet Jones (Leicester: Leicester University Press. 1993), 137. Stanley R. Sloan, NATO, the European Union, and the Atlantic Community: The Transatlantic Bargain Reconsidered (Lanham, MD: Rowman \& Littlefield Publishers, 2002), 62-3.

${ }^{87}$ Memorandum by Sir Ivone Kirkpatrick. May 11, 1950 in Roger Bullen and Margaret Pelly, eds. Documents on British Foreign Policy Overseas, Series II, Volume I, The Schuman Plan, the Council of Europe and Western European Integration, 1950-52, HMSO, 1986, 34-5.

${ }^{88}$ See letters exchanged April 21 and 22, 1948 between Morgan Phillips, General Secretary of the British Labour Party, and Leslie Hale, Ronald William Gordon Mackay papers. European papers and correspondence 1947-1950, MACKAY/5/1, accessed November 3, 2010, http://www.ena.lu/.

${ }^{89}$ The Benelux countries are Belgium, the Netherlands and Luxembourg. The term refers to the economic union that entered into force in 1948.
} 
EEC. Furthermore, many Britons questioned why Britain would wish to involve itself in European affairs, reflecting the view of a 1945 letter to the editor of The Times that "Britain is 'in' but not 'of Europe." This view was combined with a belief that the focus should be on the maintenance of the Empire as a means of ensuring British international prestige. Others claimed that only through British involvement in Europe could Britain hope to maintain its international position. ${ }^{91}$ When European integration proved successful, others began to question continued British isolation and called for closer co-operation with continental Europe. Proponents of British participation in the ECSC, Euratom and the EEC viewed economic integration as crucial to Britain's economic future. ${ }^{92}$ Since involvement in Europe would strengthen British economic and political prestige; they saw European integration and the maintenance of imperial policy not as inimical, but symbiotic.

These opposing positions on integration would remain constant as Europe moved towards integration, although the relative strength of each camp varied. Both sides had a vastly different view of the approach that Britain should take in order to maintain or restore its international prestige, but all shared a fundamental assumption about Britain's international position, namely, that their country was a natural world leader, innately well suited to the exercise of international power.

The key agents of British prestige remained the Empire and the Commonwealth. Britain emerged from the Second World War with its imperial territory intact, but financial pressure and nationalist movements forced the British to begin a process of

\footnotetext{
${ }^{90}$ Michael Field. "Britain And Europe," The Times, December 10, 1959.

91 "Double indemnity," Daily Mail. May 5, 1948.

${ }^{92}$ As an example: Peter Kirk, "Relations With Europe," The Times, April 6, 1960. Kirk was a Conservative MP at the time.
} 
decolonisation. The self-governing Dominion colonies that were dominated by British settlers had been granted full independence during the interwar period. ${ }^{93}$ After the war, Britain began granting independence to colonies not run by those of European descent, beginning with India in $1947 .^{94}$ Decolonisation continued during the 1950 s, but accelerated dramatically in the 1960s, as the British Empire was replaced by the Commonwealth of Nations. ${ }^{95}$

The Commonwealth had been established as Britain began granting independence to the 'White Dominions,' those populated by people of European descent, made up of Australia, Canada, Ireland, Newfoundland, New Zealand and South Africa. ${ }^{96}$ They were considered members of the same family, with Britain playing the role of mother and the Dominions, grown-up children. Following the granting of the independence, other former British colonies elected to join the Commonwealth, vastly changing the composition of the organisation. ${ }^{97}$ No longer dominated by Europeans who shared a similar cultural background, the Commonwealth became a multi-ethnic, multi-religious organisation. Still, the imagery of the Commonwealth as a family persisted, linked by a shared history

\footnotetext{
${ }^{43}$ The Statute of Westminster (1931) granted legislative equality and control over foreign affairs to the self-governing Dominions of Australia. Canada, Ireland, Newfoundland, New Zealand and South Africa. Ireland was not. technically, a British colony at the time of independence, but was declared a selfgoverning dominion in 1922. South Africa's political and social organisation was controlled by European settlers, although they did not form the majority of the population.

${ }^{94}$ Newly independent colonies of Southeast were often run by Oxbridge educated elite, which further cemented the relationship between Britain and the new members of the Commonwealth. African elites, however, tended to attend less prestigious British schools. Anthony Kirk-Greene, "African Rhodes Scholars, 1960-1990," in Africans in Britain, ed. David Killingray (New York: Frank Cass, 1994), 221.

95 By 1961, the following colonies had been granted independence: Canada (1867), Australia (1901), New Zealand (1907), South Africa (1910), Egypt (1922), Transjordan (1946), India (1947), Pakistan (1947), Burma (1948), Ceylon (1948), Palestine (1948), Libya (1951), Eritrea (1952), Sudan (1956), Gold Coast (1957), Malaya (1957), Nigeria (1960), Somalia (1960), British Somaliland (1960), Southern Cameroons (1960), Tanganyika (1961), Sierra Leone (1961).

96 John Oakland, British Civilization: An Introduction, $5^{\text {th }}$ edition (London: Routledge, 2002), 98

${ }^{97}$ Ireland left in 1949 and South Africa was forced to leave over apartheid in 1961. Some newly independent nations, such as Burma and British Somaliland chose not to join the Commonwealth either. Most of Britain's former colonies, however, did chose to join the organisation.
} 
and symbols, a shared language and shared values. ${ }^{98}$ The new Commonwealth was envisioned as a force for peace and stability; a multinational organisation whose goal was peaceful co-operation. The Commonwealth offered a divided world an example of how people from different backgrounds could work together based on a commitment to personal freedom, the rule of law and responsible government. ${ }^{99}$ Throughout the $1960 \mathrm{~s}$ the idea of the Commonwealth as a British community and family remained vital.

Of course, the Commonwealth also featured more concrete associations, particularly in the form of economic links. The Commonwealth made up the sterling zone, and currencies, with the exception of Canada's, were linked to the British pound. ${ }^{100}$ The economic ties between Commonwealth members had been important during the early years of the association, but by the 1960 s, Commonwealth trade was declining. Furthermore, the imperial preference system was becoming less important to Britain as its economic relations with continental Europe were strengthening, and those within the Commonwealth were weakening. ${ }^{101}$

The Treaty of Rome, and establishment of the EEC in January 1958, meant a major reorganisation of the European economy, including the abolition of internal custom duties, a common external tariff and free movement of capital and labour, as well as the promise of further integration of government policies. The EEC was a bloc that would

\footnotetext{
98 See, for example, John Diefenbaker's speech in March 1962. John Diefenbaker, "Address on what the Commonwealth represents," March 30, 1962, accessed November 6, 2010. http:/www.collectionscanada.gc.ca/2/4/h4-4016-e.html.

${ }^{99}$ Diefenbaker, "Address on what the Commonwealth represents."

${ }^{100}$ Trade was governed by the Ottawa Agreements which set out a system of imperial preference. The Commonwealth featured limited internal tariffs which fostered trade amongst members. Ottawa Agreements Bill, 1931-32 (127) III.1.

${ }^{101}$ Between 1951 and 1960 British trade with the countries of the EEC had doubled. Trade with Australia. New Zealand and South Africa had declined and trade with Canada and the Asian members of the Commonwealth had remained constant. Nations Unies, Annuaire Statistique 1961 (New York: Bureau de statistique de l'Organisation des Nations Unies, 1961), 418-19.
} 
eventually challenge British economic interests, leading many politicians to ponder alternative arrangements to ensure access to European markets. ${ }^{102} \quad$ In 1960 , Britain joined with Austria, Denmark, Norway, Portugal, Sweden and Switzerland to form the European Free Trade Association (ETFA). ETFA did not deliver the hoped for economic returns: British exports to ETFA members rose by thirty-three percent, but exports to the EEC rose by fifty-five percent in spite of escalating tariffs. ${ }^{103}$ Furthermore, ETFA did not improve Britain's bargaining position, as the EEC did not view the organisation as a potential threat to its economic power as European integration proved rapidly successful. With the exception of Belgium, the members of the EEC enjoyed economic growth that far exceeded that of Britain. ${ }^{104}$

By 1960 , Britain was left with the threat of exclusion from some of the larger markets and increasingly dependent on declining Commonwealth trade relationships. Clearly ETFA did not have the economic strength to compete with the Six. Furthermore, Britain faced domestic economic problems that began with a balance of payments crisis early in 1960 as Britain's deficit amounted to 228 million pounds. Britain was also faced with a sterling crisis in 1961.This problem was coupled by rampant inflation which finally resulted in deflationary measures in July $1962 .{ }^{105}$ For many economists,

102 Richard Griffiths, "A Slow One Hundred and Eighty Degree Turn: British Policy Towards the Common Market, 1955-60," in Britain's Failure to Enter the European Community, 1961-63, ed. George Wilkes (London: Frank Cass \& Co., 1997), 39. 1995), 131.

${ }^{103}$ Richard Lamb, The Macmillan Years, 1957-1963: The Emerging Truth (London: John Murray,

${ }^{104}$ May. 31.

${ }^{105}$ Alec Caimcross, The British Economy Since 1945: Economic Policy and Performance, 1945$19952^{\text {vd }}$ edition (Oxford: Blackwell, 1995) 139-40. 
membership in the EEC offered an opportunity to reverse Britain's economic difficulties $^{106}$

The main impetus for membership, however, was political. The Foreign Office maintained that the EEC's political and military strength would increase dramatically while Britain's would decline. ${ }^{107}$ The possibility that Britain might lose its position as the pre-eminent European power was unthinkable. Britons took for granted the idea that Britain was destined to play a leadership role not only in Europe, but in international affairs. The idea that the EEC could supersede Britain was unthinkable, but it was becoming clear that political influence in Europe was directly tied to membership in the EEC. Furthermore, Britain was increasingly concerned about the maintenance of its 'special relationship' with the United States. ${ }^{108}$ Forced into the position of a second class power, dependent on the United States, British officials feared that the Six would take Britain's place as the dominant European power in American policy. ${ }^{109}$ Coupled with the changing political nature of the Commonwealth and the decline in British influence, Britain was increasingly isolated. As a result, historians have suggested that the British application to join the EEC was an attempt to restore its position as the centre of Churchill's intersecting circles: Europe, the United States and the Commonwealth. ${ }^{110}$

\footnotetext{
106 Hugh Pemberton, "A Taxing Task: Combating Britain's Relative Decline in the 1960s," Twentieth Century British History 12, no. 3 (2001): 361.

${ }^{107}$ Wolfram Kaiser, "To Join or Not to Join: The 'Appeasement' Policy of Britain's First EEC Application," in From Reconstruction to Integration: Britain and Europe Since 1945, eds. Brian Brivati and Harriet Jones (Leicester: Leicester University Press, 1993), 145.

${ }^{108}$ See Alan Dobson, "The Years of Transition: Anglo-American Relations, 1961-1967," Review of International Studies 16, no. 3 (1990): 239-58.

109 "Report of the European Economic Association Committee of the Cabinet, May 25 1962." in Britain and European Integration Since the Second World War, ed. Sean Greenwood (Manchester: Manchester University Press, 1996), 119.

${ }^{110}$ May, 32.
} 
On July 31, 1961, right before the summer recess, Prime Minister Harold Macmillan announced to the House of Commons that Britain intended to seek membership in the EEC. Macmillan's speech foreshadowed the themes that would be prevalent in the press debates of the next two years. He acknowledged that European integration was both "a political as well as an economic issue and that political union would prove far more controversial as Britons struggled with the idea of surrendering some of Parliament's sovereignty."111

The Prime Minister also realised that Britons would be concerned about the effects on the Commonwealth of British participation in the Common Market. Britons still retained a deep emotional attachment to the Commonwealth, regardless of the weakening political and economic links. They would be unlikely to support an endeavour that threatened its strength. Macmillan openly acknowledged these fears, reassuring Members of Parliament that his Government's policy would not damage Commonwealth relations:

I believe that it is both our duty and our interest to contribute towards that strength by securing the closest possible unity within Europe. At the same time, if a closer relationship between the United Kingdom and the countries of the European Economic Community were to disrupt the longstanding and historic ties between the United Kingdom and the other nations of the Commonwealth the loss would be greater than the gain. The Commonwealth is a great source of stability and strength both to Western Europe and to the world as a whole, and I am sure that its value is fully appreciated by the member Governments of the European Economic Community. I do not think that Britain's contribution to the Commonwealth will be reduced if Europe unites. On the contrary, I think that its value will be enhanced. ${ }^{112}$

\footnotetext{
${ }^{111}$ Harold Macnillan, Speech to the House of Commons, July 31, 1961, Parliamentary Debates, $5^{\text {th }}$ ser., vol. 645 (1961), col. 928 .

112 Macmillan, col. 929.
} 
Far from damaging the Commonwealth, Macmillan argued that it would be strengthened by British membership in the EEC. This would come about because the Common Market would reinforce Britain's economic position, and this in turn, would lead to greater stability within the Commonwealth. The decline in British international prestige was a greater threat to the health of the Commonwealth, since its survival was dependent on Britain's economic and political strength. Membership in the EEC would ensure that the Commonwealth remained, in Macmillan's words, a "great source of stability and strength" for the world.

The Parliamentary response to Macmillan's announcement featured the same tone and themes that would permeate future debates over British participation in the Common Market. The Labour Leader, Hugh Gaitskell, was clearly somewhat hesitant about British membership in the EEC, but refused to commit to a firm position. He stated that Macmillan had not announced that Britain would seek to join the Common Market, but had simply indicated the terms under which participation might be possible. ${ }^{113}$ Labour's ambivalence about British membership would continue for more than a year, as the debate over the Common Market spread across Britain.

Gaitskell did raise several concerns about how the Common Market would affect Britain's existing economic relations, including the other countries of EFTA. Even more important was the question of the Commonwealth. Gaitskell did not claim that the EEC would adversely affect the Commonwealth, but British participation in the Common Market would clearly affect the Ottawa Agreements that currently governed trade. In the House of Commons, Gaitskell stated that "whether [the] terms and conditions are or are

\footnotetext{
${ }^{113}$ Hugh Gaitskell, Response to the House of Commons, July 31, 1961, Parliamentary Debates, $5^{\text {th }}$ ser., vol. $645(1961)$, col. 931 .
} 
not satisfactory is a matter on which, obviously, the Commonwealth Governments must have an opportunity of expressing a view ... [and he asked that the Prime Minister] ... give a pledge that before any final decision is taken on this [that] there will definitely be a Commonwealth Prime Ministers' conference ..."114 Gaitskell clearly believed that the Commonwealth Prime Ministers had a right to be consulted over a decision that would fundamentally alter their economic policy.

Macmillan agreed with Gaitskell that the position of the Commonwealth had to be respected, and explained that if the negotiations reached a point where British membership looked to be a real possibility, a formal meeting with the Commonwealth Prime Ministers would be held. He reassured Parliament that "at every point the Commonwealth will be consulted."115 In fact, the Macmillan government had already decided that membership in the EEC was the best way of protecting British interests.

Edward Heath took charge of the British negotiations, which proceeded throughout 1961 and 1962 . Negotiations with the Six were complicated by the fact that Britain's policies in three key areas differed vastly from those of the EEC, namely in agriculture, relations with ETFA and with the Commonwealth. The latter would prove to be the most problematic. Britain faced the EEC's refusal to consider the continuation of the old imperial trading preference as well as the Commonwealth's suspicion that the British were abandoning them in favour of Europe. ${ }^{116}$ The Commonwealth Conference was finally scheduled for September 1962.

${ }^{114}$ Gaitskell, col. 932.

${ }^{115}$ Gaitskell clearly articulated this fear in the House of Commons. Gaitskell, col. 932.

${ }^{116}$ May, 34. 
The primary purpose of the Commonwealth Conference was to discuss how British membership in the EEC would affect the Commonwealth. The meetings would also provide a forum for the discussion of Commonwealth concerns over trade relationships and the future of the association. All members of the Commonwealth were invited to attend. This series of meetings would be the first where Sierra Leone, Tanganyika, Jamaica and Trinidad and Tobago attended as full members, making it the largest Commonwealth Conference to date with 16 countries represented. ${ }^{117}$ The meetings would be significant because they would challenge assumptions concerning the position of the Commonwealth in British life, revealing deep divisions in British society over the essential components of British national identity.

${ }^{117}$ Commonwealth Prime Ministers Meeting, 1962: Final Communiqué (London: Her Majesty's Stationary Office, 1962), 2. 


\section{Chapter: A Family Reunion - the Commonwealth Conference}

The Commonwealth Conference participants began arriving in London on September 4, 1962. The Australian and New Zealand Prime Ministers were first, greeted by family members living in Britain, a reunion that was a living and tangible illustration of the bonds that united Britain and the old settler colonies of Australia, Canada and New Zealand. ${ }^{118}$ Menzies and Holyoake were not foreign leaders; they were members of a family with a shared (imperial) history now under threat from Macmillan's European project. $^{119}$ They were not, however, visiting Britain to attend a pleasant family gathering, since their forthcoming meetings sought to address the Commonwealth's concerns over Britain's possible entry into the EEC. ${ }^{120}$ According to Menzies, the Prime Ministers wished to protect the Commonwealth, a legacy that belonged to every Briton. ${ }^{21}$ In its commentary, the anti-Common Market Daily Express stated that the Commonwealth held faith that the mother country would not abandon the family, but fear of desertion cast a long shadow over the news columns of the Express. ${ }^{122}$ It characterized the course steered by the British Prime Minister toward Europe as a betrayal of the historic legacy of the Conservative Party ${ }^{123}$ and decried his tactics as those of a schoolyard bully who pressured newer members of the Commonwealth to support his

118 The Daily Herald printed photographs of Robert Menzies being embraced by his granddaughter and Keith Holyoake being embraced by his daughter, both of whom were living in Britain. Daily Herald, September 5, 1962.

119 Ibid.

120 “Empire Premiers Fly In," Daily Express, September 4, 1962; Victor Knight, "Market is First for Premiers," Daily Mirror, September 4. 1962; "Commonwealth Arrivals," Guardian. September 3. 1962: Francis Moir, "Premier Will Be Told: Keep Market Pledge," Daily Herald, September 7, 1962: "Common Market to Dominate Prime Ministers' Talks," The Times, September 4, 1962.

121 "Page 1 Quotes," Daily Express, September 5, 1962.

122 "The Empire Speaks Out," Daily Express, September 5, 1962.

${ }^{123}$ Ibid. 
position on the Common Market against the wishes of the older, more established members such as Australia, Canada and New Zealand. ${ }^{124}$

The Commonwealth Conference opened on September 10,1962 and the meetings concluded with the publication of a communique on September 19. Conflict between Macmillan and the Commonwealth leaders was expected by all the newspapers, but they did not agree on any other aspect of the discussions. For example, a reader would have found it difficult to reconcile the Daily Express's claim that Macmillan was in a crisis after being attacked by the Commonwealth with The Times's claim that the Prime Minister had been applauded by the delegates, ${ }^{125}$ since the newspapers interpreted the Conference results according to their own understanding of Britain's future and the consequences of membership in the EEC. In spite of the gulf between the newspapers' political positions, many commonalities can be found in the press's discussion of the future of the Commonwealth and British membership in the EEC. The common use of language, symbols, and assumptions concerning Britain's international role illustrate the continued dominance of traditional constructions of national identity in public discourse throughout September 1962. The content of the articles and editorials differed widely, but they demonstrate the continuity of assumptions about the central importance of the Commonwealth to Britain. While the press was not, for the most part, directly addressing the construction of British national identity, the newspapers all assumed that the Commonwealth was a defining feature of Britishness.

\footnotetext{
${ }^{124}$ Douglas Clark, "It's Tough! Empire Men Seek Second Conference," Daily Express, September 8, 1962; Harmar Nicholls, "A Speech for Macmillan," Daily Express, September 7, 1962.

${ }^{125}$ Douglas Clark, "Crisis Hour for Premier," Daily Express, September 10, 1962; "Opportunity in Europe, Says Mr. Macmillan," The Times, September 11, 1962.
} 
The continued relevance of the Commonwealth was aptly demonstrated in the language used by the various newspapers in discussing Commonwealth relations. The persistent use of the language and symbols of the Empire reflected British public discourse and reinforced the importance of Britain's imperial past to its national identity. Familial terms were used by all of the newspapers. There was the implication that Britain and the other members of the Commonwealth were part of the same community, formed by shared blood and traditions. Familial language predominated even in the newspapers most committed to British membership in the EEC. In an editorial entitled "The Marriage is Not Yet Arranged," the Guardian used the image of a wedding to describe the state of British foreign relations. ${ }^{126}$ Macmillan was compared to a wealthy orphaned daughter who wishes to marry someone she does not know well, namely, continental Europe. Her sisters, the Commonwealth countries, do not trust the fiancé, but are not in a position to stop the bride from following through with the wedding. The bride wishes to avoid a family feud over her nuptials, but is unwilling to postpone the wedding too long, in case the groom becomes frustrated and walks away. The Guardian recommended listening sympathetically to the sisters since Britain's wedding with Europe would weaken ties with the Commonwealth as well as with the United States. The sisters who are left behind will no doubt feel slighted, but the Guardian predicted that the marriage would prove a happy and profitable one for Britain, the Commonwealth family and its American friends. ${ }^{127}$ The Guardian advocated British membership in the EEC, believing

\footnotetext{
126 "The Marriage is Not Yet Arranged," Guardian. September 5, 1962.

${ }^{127}$ Ibid.
} 
that Britain's future lay in Europe, but it also could not escape using the imagery of the Commonwealth as a family and a community. ${ }^{128}$

This idea of the Commonwealth family was a theme that ran through much of the Commonwealth Conference press coverage. Since the press must use the language and experiences of its public, the newspapers' consistent and recurrent use of this imagery suggests that the British public continued to believe that the Commonwealth was, in essence, a family.

There had, however, been changes within the 'family' as the old colonies had 'grown up.' The Daily Herald emphasised that the Commonwealth was no longer characterised by a system of dependence and was now an association of equals who chose to remain together because of shared values and institutions established during imperial rule. ${ }^{129}$ The newspaper claimed that without them, 'outsiders' would find membership in the Commonwealth community difficult. ${ }^{130}$ Formal links between

${ }^{128}$ This community, however, was under great pressure and the newspapers were unsure as to whether the Commonwealth Conference would degenerate into a battlefield. All except the Guardian agreed that British participation in the Common Market was the primary reason that the Commonwealth leaders had made the trip to London. The Guardian maintained that the Cold War and East-West relations were of greater importance than the Common Market for most of the Commonwealth, but did acknowledge that the debate over British membership in the EEC was likely to dominate the conference. The Daily Mirror, The Times and the Guardian expressed their hope that the meetings between Macmillan and Commonwealth leaders would clear up misunderstandings about the British application. British membership in the Common Market was not intended to harm Commonwealth relations; in contrast, by strengthening Britain's economic position, the entire Commonwealth would be more secure. "Empire Premiers Fly In," Daily Express, September 4, 1962; Victor Knight, "Market is First for Preniers," Daily Mirror, September 4, 1962; "Common Market to Dominate Prime Ministers' Talks," The Times, September 4, 1962; Francis Moir, "Premier Will Be Told: Keep Market Pledge," Daily Herald, September 7, 1962.

${ }^{129}$ While theoretically a country that was never part of the British Empire could apply to join the Commonwealth, this possibility was unlikely. Today the only members of the Commonwealth that do not have direct links to the British Empire are Mozambique (a former Portuguese colony) and Rwanda (a former Belgian trust and German colony).

${ }^{130}$ Christopher Hall, "Links That Form the Commonwealth," Daily Herald, September 11, 1962. The Daily Herald explained that the Commonwealth was a loose association whose member nations were all former British colonies, plus Britain itself. There were no hard and fast rules of membership, but generally a meinber country had to have full independence, be willing to accept the Queen as the symbol of the Commonwealth, and be acceptable to other members. The association functioned as a way of 
Commonwealth countries were waning, but the association was still united by shared values and institutions.

The strength of the Commonwealth was said to be a "common mind" that developed because of "values of kinship and tradition and trade."131 Many of the members shared bonds of kinship; those that did not still shared the same traditions and values in their devotion to fundamental human rights, rule of law, democratic government, and the equal rights of men and nations. These values had developed because of their shared association with Britain. The Commonwealth was a "unique and heart warming association" that brought diverse peoples together in "a fraternal spirit of equality and mutual respect." 132 At its heart, the Commonwealth was a "family of nations." 133 Members remained committed to this principle; they only asked that the British government did the same by proving that family loyalty was still a priority for the mother country.

The emotional attachment to the former colonies persisted even though most Britons were uninformed about the Commonwealth. ${ }^{134}$ As long as Britons maintained a firm belief in the Commonwealth as a family, Britain would be inherently linked to its

organising countries that shared a similar heritage and set of values. The newspaper described two main links between Commonwealth countries: consultative and economic. Members were not bound to each other, but a gentlemen's agreement dictated that before taking major international action the Commonwealth should be consulted. Trade links were important because all members, save Canada, were part of the Sterling Area.

131 "Something More Than Sentiment," The Times, September 4, 1962; "Strength and Frailty of Tradition," The Times, September 5, 1962.

132 "Strength and Frailty of Tradition," The Times, September 5, 1962; "Unique Achievement or Illusion?" The Times, September 6, 1962.

133 "Unique Achievement or - Illusion?" The Times, September 6, 1962

${ }^{134}$ In one particular anecdote printed in the Guardian, a man mistook the Canadian flag for the Australian flag. Still, he maintained to his young son that there was a real emotional connection between the British public and the Commonwealth. This anecdote demonstrated a father passing on traditional constructions of national identity to the next generation. "Flags in the Sun," Guardian. September 10, 1962. 
former colonies and could not act without consideration for the Commonwealth. For the Daily Herald, the real bond of the Commonwealth was emotional and personal. Britons were fascinated by the Commonwealth and its traditions. ${ }^{135}$ Above all, the Commonwealth was still perceived as a family, in spite of the infighting. In its headline of September 14, 1962, the newspaper proclaimed "At this moment of crisis, they're still a family." 136 As long as the members of the British public continued to believe that they were inherently connected to the Commonwealth, its importance to national identity remained unchanged. The Daily Mirror claimed that young people looked to the Common Market as their future. ${ }^{137}$ The Daily Herald was less convinced. The newspaper regularly interviewed young people in a feature called "Under 25." When asked about the choice between the Common Market and the Commonwealth in an article run on September 19, 1962, four participants claimed that they placed a higher priority on maintaining Atlantic links rather than turning towards Europe whereas three believed that the Commonwealth had outlived its purpose or was unimportant. ${ }^{138}$ The youth appeared as divided as rest of the British public. One of those interviewed, Ann Clayton gave her opinion using the same language as the older generation: "I regard the Commonwealth as a family of nations, something good that should be preserved. That is why I hope that Britain does not join the Common Market. Such a move would eventually mean the end of the Commonwealth as it is now."139 As long as the British public maintained its belief in the Commonwealth community, Britain would be tied

\footnotetext{
135 "Market Day," Daily Herald, September 11, 1962.

136 "At This Moment of Crisis They're Still a Family," Daily Herald, September 14, 1962.

137 "Who Dare Say the Price is Too High?" Daily Mirror, September 11, 1962.

138 "Under 25," Daily Herald, September 19, 1962.

139 "Under 25," Daily Herald. September 19, 1962.
} 
more firmly to its former colonies than to continental Europe. No political party could afford to run ahead of the public.

The Daily Express agreed that Britain was still inherently tied to the Commonwealth and argued for the importance of maintaining these links. ${ }^{140}$ For example, the newspaper pointed out that the Queen's dinner with Commonwealth leaders was not a state banquet, but a lady entertaining her family. ${ }^{141}$ The use of familial language echoed throughout the Express's assessment of Commonwealth relations. In both text and cartoon, the newspaper used the concept of parent and child to illustrate Commonwealth relations. As a parent grieves when a child leaves home, granting independence was difficult for Britain, but the family ties remained. As illustrated in the Daily Express's editorial cartoon of September 12, children must grow up, but continue to be part of their parents' family. They move out from under their parents' roof, but it still remains 'home.' The Empire had become the Commonwealth, but the family unit remained intact. Macmillan was now seeking to break up this unit by abandoning the family to pursue closer relations with Europe. The implication was that his imprudent policies might well destroy the Commonwealth.

140 "The Hour of Decision," Daily Express, September 12, 1962.

${ }^{141}$ William Barkley, "The Empire in September, 1962," Daily Express, September 14, 1962. 
Figure 1 Daily Express, September 12, 1962

The Daily Express did not claim that Macmillan had set out to ruin the Commonwealth. Rather, as seen in a Cumming's cartoon from September 14, Macmillan hoped to preserve close Commonwealth relations within a wider European arena. This hope was foolhardy - the Daily Express recognised that the EEC would not accept special conditions for the Commonwealth. ${ }^{142}$ Macmillan had misplaced his priorities. The family must come first. The newspaper believed that Macmillan would regret his betrayal of this family of nations, as he would find himself alone in Europe, without the support of the Commonwealth or even the cooking..."

142 The caption reads "In the end I just came by myself - the family can't stand Continental 
British people. There was no room for the Commonwealth in the Treaty of Rome, and Britons could not envision a future outside of the British family of nations. Macmillan would have to choose between the Commonwealth and his European policy. The Daily Express feared that he had already chosen to sacrifice the family.

The Commonwealth, however, was not simply a family. The Empire had been the vehicle through which Britain exercised much of its international influence, and many Britons believed that the Commonwealth was the obvious way for Britain to retain its world role. For the Express, the political and cultural ramifications of a possible dissolution of the Commonwealth, in exchange for participation in the Common Market were unthinkable, as it would mean the end of Britain's ability to influence world affairs. ${ }^{143}$ To underscore the importance of the Commonwealth, the Daily Express chose its words carefully. While the Commonwealth was not synonymous with the British Empire, the Express emphasised the continuity between the two. The headline for its report on the arrival of the Commonwealth leaders in London read "Empire Premiers Fly In. ${ }^{\prime 144}$ While the granting of independence had changed the formal political relationship between Britain and its former colonies, the newspaper presented the Commonwealth as an evolution of the Empire rather than as a new entity; as Britain had been the centre of the Empire, so it remained the centre of the Commonwealth. ${ }^{145}$ Not insignificantly,

143 "The Hour of Decision," Daily Express, September 10, 1962.

${ }^{144}$ "Empire Premiers Fly In," Daily Express, September 4, 1962.

${ }^{145}$ London continued to be a city of the world in which all members of the Commonwealth could feel at home. For an earlier example of the same attitude, see "London As It Strikes a Stranger," Temple Bar, 5 (June 1962): 379-88. This text is a report written by a visitor from the Empire in which he expresses his disgust that Britain's imperial capital, London, cannot aesthetically compare with Paris. More importantly, however, it also demonstrates a belief that all inhabitants of the Empire are members of a greater community and that London does not belong to Londoners, but is a physical manifestation of the Empire. 
throughout its coverage of the Conference, the Daily Express used the terms 'Empire' and 'Commonwealth' interchangeably.

The Daily Express underscored for its readers the fundamental connections between Britain and the Commonwealth. One example is found in the coverage of Nigerian Prime Minister Abubakar Tafawa Balewa's arrival and his statements regarding the British application. The Daily Express's coverage of Balewa's statement on the Common Market focused on the importance of the relationship between Nigeria and Britain, using it as a microcosm of Commonwealth relations. Voicing his own concerns and those of other Commonwealth countries, Balewa stated that: "Britain is the root from which we all spring. How could she throw us away now?" 146 This comment was perhaps all the more striking for having been made by an African leader. Britain's colonial activity had created countries in Africa, America, Asia and the South Pacific that shared a commitment to democratic values and the rule of law. Shared values and experiences had created a community that stretched far beyond Britain's shores, but whose 'root' was firmly planted on the island. It had forged indelible links with indigenous peoples who, although now independent and sovereign, claimed ownership of the Commonwealth community and freely recognised Britain as that organisation's 'root', providing life to the branches. In return, as the Daily Express was not slow to suggest that, as the branches flourished and expanded, Britain's international influence would be enhanced.

Even the newspapers that supported British entry into the EEC found it difficult to conceive of Britain being unable to exert international influence, although unlike the

146 “Holyoake Flies in With a Protest," Daily Express, September 5, 1962. 
Daily Express, they acknowledged that the world had changed since the high days of Empire. The Guardian did not pull any punches with its readers, bluntly pointing out that Britain was no longer able to sustain her international position alone; ${ }^{147}$ only in partnership with other European powers in the EEC could Britain hope to regain her rightful place as a world leader. ${ }^{148}$ Proponents of British membership in the EEC were convinced that Britain would be the dominant force in Europe. Britain, the Guardian believed, was innately superior to continental Europe: its imperial history, island status and experience as a world superpower made Britain the natural leader of a united Europe. Indeed, the pro-European assumptions of the Guardian reveal much about the continued importance of historic constructions of British national identity. The Guardian looked forward to the future offered by Europe, but its belief in the centrality of the Commonwealth exposed the greater importance of history and tradition in the construction of British national identity. The nature of the association was changing, but in 1962 even the pro-European newspapers found it difficult to imagine Britain without the Commonwealth.

Still, the changing role of the Commonwealth did necessitate a change in political and economic policy. As part of an effort to explore these changes and the new role of the Commonwealth in British life, the European leaning Times published various articles that focused on the evolution of former imperial links. This approach attempted to educate readers and subtly suggested that the Commonwealth could not continue its

\footnotetext{
147 "The Marriage is Not Yet Arranged," Guardian. September 5, 1962.

148 "More World Influence in EEC," Guardian, September 8, 1962.
} 
central role in British national identity. ${ }^{149}$ The Commonwealth's shared symbols and history made it seem like a cohesive community, but both the Guardian and The Times reminded their readers that it was an organisation of independent states, not the British Empire.

The Times found that support for the Commonwealth remained high throughout most of the member countries, but many feared that it might be damaged on the grounds that were Commonwealth economic links to be weakened because Britain joined the Common Market, political links might wither as well. ${ }^{150}$ Australians were concerned that Britain would be unable to persuade the Six to take a more outward looking position. In consequence, Britain would become too focused on Europe, neglecting its international links with the Commonwealth. Pakistan expressed a similar fear: Britain could not remain the centre of a global association if it became too preoccupied with a regional organisation. $^{151}$ Europe's threat to the Commonwealth was therefore not merely economic; it threatened the structure and priorities of the whole association.

The Commonwealth offered its members a unique opportunity to participate in international affairs on a level that would not be possible individually. India saw the

149 The newspapers approached the topic from different viewpoints, reflecting their different audiences. The Daily Herald's article was largely informative, and intended to educate its readers on the design and the purpose of the Commonwealth. In contrast, the Guardian and The Times assumed that their audience understood the institutional underpinnings and was more interested in the meaning of the Commonwealth and its continuing relevance. These articles explored how various member countries saw the Commonwealth, focusing primarily on its strengths and weaknesses Christopher Hall, "Links That Form the Commonwealth," Daily Herald, September 11, 1962; The Times ran a series of articles entitled "Reality of the Commonwealth" over four days. The articles included: "Something More Than Sentiment," The Times, September 4, 1962; "Strength and Frailty of Tradition," The Times, September 5, 1962; "Unique Achievement or - Illusion?" The Times, September 6, 1962; and "Divided Views of the New Members," The Times, September 8, 1962.

150 "Something More Than Sentiment," The Times, September 4, 1962; "Strength and Frailty of Tradition," The Times, September 5. 1962.

151 "Something More Than Sentiment," The Times, September 4, 1962. 
Commonwealth as offering the possibility of having "independence plus." 152 The Commonwealth was a way for India to avoid isolation in world affairs, while pursuing its policy of non-alignment. Various African members expressed the same view as many newly independent African countries also wished to avoid becoming embroiled in the East-West divide. ${ }^{153}$ The Commonwealth allowed them to pursue this policy. Moreover, members could participate in a global multiracial organisation that allowed for mentoring and a peaceful transition to independence. ${ }^{154}$

Britain's application to join the EEC was a fundamental shift in British foreign policy and such a change would, inevitably affect its Commonwealth partners. All the newspapers recognised that Britain's application to join the EEC had caused anxiety within the Commonwealth. Pro-Market newspapers recognised that Macmillan had a difficult task ahead of him, as Commonwealth leaders remained unconvinced that the Common Market did not threaten the Commonwealth's survival. ${ }^{155}$ Resentment against Europe grew in a number of Commonwealth member countries: Macmillan claimed that British membership in the EEC would strengthen the community, but the Commonwealth was less convinced. ${ }^{156}$

152 "Strength and Frailty of Tradition," The Times, September 5. 1962.

153 "Divided Views of the New Members," The Times, September 8, 1962.

154 "Unique Achievement or-Illusion?" The Times, September 6, 1962.

${ }_{155}$ Patrick Keatley, “Major Task Faces Mr Macmillan," Guardian, September 8, 1962.

156 "Touring MP Found Resentment and Anxiety in Commonwealth," Guardian, September 8, 1962. 
The battle lines appeared to be hardening, with Macmillan on one side and the Commonwealth leaders on the other. This division was aptly illustrated by David Low in the Guardian. His September 5 cartoon shows Ted Heath preparing for a boxing match while his sparring partners arrive, from left to right they are: Roy Welensky from Rhodesia, Jawaharlal Nehru from India, John Diefenbaker from Canada, Figure 3 Guardian, September 5, 1962

Robert Menzies from Australia and Keith

Holyoake from New Zealand. Macmillan dressed as a coach or manager looks on from the ring. Heath's speed bag is labelled "Common Market", the match's prize. Boxing is a solo sport. In order to win the match, Heath would have to practice his skills against these determined and strong opponents. Each country's concerns would have to be addressed individually. Negotiations with the Six were still ongoing in September 1962. The Commonwealth looked poised to make its mark and to afford Heath an exacting workout. $^{157}$

157 Patrick Keatley, "Premiers Likely to Meet Next Year," Guardian, September 5, 1962. The Guardian even welcomed Diefenbaker's suggestion that alternative solutions to British economic woes should be discussed, believing that before a final decision was inade, all the possibilities needed to be examined. "What Alternatives," Guardian, September 8, 1962. 
Both The Times and the

Guardian agreed that conflict was inevitable, but that British membership in the EEC was necessary in order to maintain the country's international prestige and influence. $^{158}$ The Guardian commented on the distrustful mood of the Conference with a Low's cartoon on September 11, 1962 which showed Macmillan about to enter the Common Figure 4 Guardian, September 11, 1962 Market Office. He is tied to strings that are controlled by various Commonwealth leaders. Low's message appears to be that Macmillan, and by extension Britain, was not acting independently, but was constrained by the Commonwealth: "just go in and tell him you won't be pushed around." With heavy irony, Low suggested that while some Britons were concerned about the potential loss of sovereignty inherent in European integration, the Commonwealth was limiting British sovereignty. ${ }^{159}$ Of the two quality newspapers, the Guardian's coverage was more sympathetic to the Commonwealth than The Times. Macmillan might insist that Britain was not faced with the choice between Europe and the Commonwealth, but the Guardian held that he was not terribly convincing. ${ }^{160}$ The

158 Patrick Keatley, "Diamond Hard' Resolve..." Guardian, September 10, 1962; "Coinmonwealth Ministers' Hard Bargaining," The Times, September 10, 1962; "Striking the Balance," The Times, September 10, 1962; "Opportunity in Europe, Says Mr. Macmillan," The Times, September 11, 1962; "Prime Ministers' Day of Doubts," The Times, September 12, 1962; "Hope of More Concessions," The Times, September 12, 1962; "Talks Ending on Monday," The Times, September 15, 1962.

${ }^{154}$ Guardian, September 11, 1962

160) Patrick Keatley, "Premier Strikes No Sparks," Guardian, September 11, 1962; "Prenier's Assault on EEC," Guardian, September 12, 1962. 
most poignant arguments were moral and emotional. The Commonwealth had stood by Britain in its hour of need. How could Britain now abandon the Commonwealth? ${ }^{161}$ Developing nations feared that Britain was joining a "rich man's club," and abandoning its friends. ${ }^{162}$ Unless Macmillan could persuade the Commonwealth of the benefits of the Common Market, he might very well be faced with a choice between the two and it was the Commonwealth that held public loyalties. ${ }^{163}$

The Daily Herald was certainly not one for sacrificing old friends; it began its coverage of the Commonwealth meetings by emphasising the importance of the Commonwealth as a unit. ${ }^{164}$ If the price of the Common Market was too high for the Commonwealth as a whole, then British policy needed to be reassessed, since the individual members had to consider how to best meet the needs of the entire family. ${ }^{165}$ The Conference proceedings demonstrated the complicated nature of British membership in the EEC. ${ }^{166}$ Diefenbaker questioned whether Britain would lose its individual identity in order to become a European nation. ${ }^{167}$ The Daily Herald believed that many Britons shared this concern. ${ }^{168}$ Macmillan's unwillingness to compromise, or to reopen negotiations, did not endear him to either the Commonwealth or to the British public. ${ }^{169}$

\footnotetext{
${ }^{162}$ Patrick Keatley, "Negative Approach by EEC Critics," Guardian, September 13, 1962.

163 "The Government's Dilemma," Guardian, September 13, 1962.

164 "At the Crossroads," Daily Herald, September 10, 1962.

165 "Macmillan in Market Crisis Today," Daily Herald, September 11, 1962. The Daily Herald
} 1962.

${ }^{161}$ Patrick Keatley, "Moral Argument May be the Telling Weapon," Guardian, September 12. printed Labour's statement in full on September 10. "Get Better Terms - or Keep Out," Daily Herald, September 10, 1962.

${ }^{166}$ David Watt and Francis Moir, "Challenge to Macmillan," Daily Herald, September 12, 1962.

${ }^{167}$ Ibid.

${ }^{168}$ David Watt and Francis Moir, "Macmillan Goes A-Wooing," Daily Herald, September 13, 1962; David Watt and Francis Moir, "Macmillan Keeps at Market Task," Daily Herald, September 15, 1962.

\footnotetext{
${ }^{169}$ David Watt and Francis Moir, "Don`t Fence Me In!" Daily Herald. September 18, 1962.
} 
According to the Daily Herald, Macmillan did not appear to understand the depth of concern over the impact the Common Market might have on British national identity.

As the meetings progressed, the Daily Express repeatedly claimed that Macmillan was "in crisis", "desperately" attempting to soothe and convince the Commonwealth leaders. ${ }^{170}$ One cartoon, for example, showed him prostrate and heavily bandaged as a result of the forcefulness of the Commonwealth's arguments. The cartoon's humour is to be found in the ironical use of a phrase from a famous speech made by Macmillan in July 1957: 'Never had it so good'. ${ }^{171}$

Figure 5 Daily Express, September 13, 1962

Another cartoon, from September 14, portrayed him tiptoeing, carrying sedative tablets and soothing syrup, and a hypnotism book in his back pocket. The image suggested that Macmillan's attempt to convince Commonwealth leaders of the Common Market's value by rational means had failed, and that he had resorted to drugs and hypnotism.

In stark contrast to the British Prime Minister, the

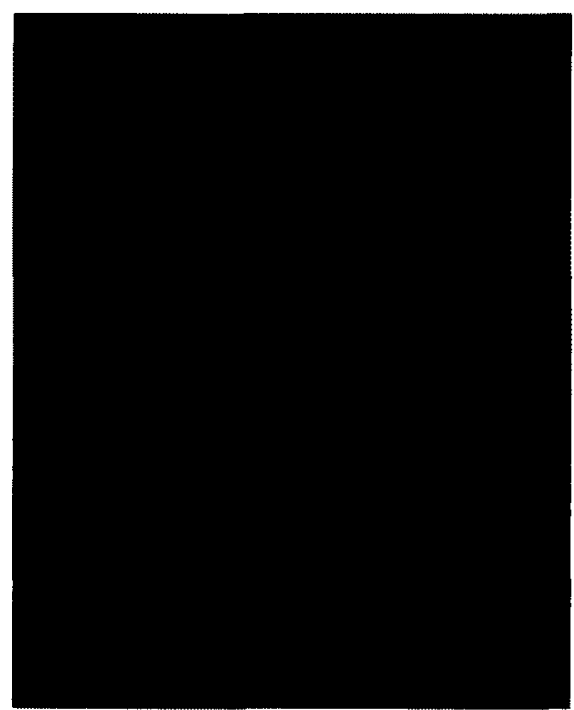

Figure 6 Daily Express, September 14, 1962

${ }^{170}$ Douglas Clark, "Dief Sounds Warning," Daily Express, September 11, 1962; Douglas Clark, "Live and Let Live," Daily Express, September 14, 1962; Alexander Kenworthy. "Premier Will Try Again on Monday," Daily Express, September 15, 1962.

${ }^{171}$ Harold Macmillan, in a speech in Bedford, July 1957, in The Long March of Every' Man. 17501960, ed. Thomas Barker (London: Penguin Books, 1978), 290-1. 
Canadian Prime Minister, John Diefenbaker, was portrayed in the Daily Express as a hero; one who had warned Macmillan that British policy would destroy the Commonwealth and who argued that one could thrive beside a powerful neighbour. ${ }^{172}$ In another Cummings cartoon, illustrating the Commonwealth Conference as a tug of war, Diefenbaker is front and centre, leading the battle against Macmillan. The Australian Prime Minister, Robert Menzies, is the anchor, holding steady and aiding Diefenbaker in the fight, with Nehru in the middle. On the opposite side, Macmillan, apparently isolated, works alone, pulling Britannia towards Europe while Britannia herself, with shocked expression, is unable to affect her own destiny. Except for Rhodesia and Trinidad, the entire Commonwealth stood united against Macmillan, "a magnificent array of power" that demonstrated "the magnetism of the Commonwealth ideal." ${ }^{173}$ Nor could the Commonwealth's opposition to Britain's entry into Europe be hidden by a final communiqué about common goals. ${ }^{174}$ The Daily Express advocated the discarding of "a policy that threatens the Commonwealth with disunion and ruin ... [and encouraged the abandonment of] the whole mad enterprise in Brussels." ${ }^{175}$ The Commonwealth Conference, the Express opined, had opened a public debate that would not end when the leaders left London since the battle of the premiers would be replaced with the battle of

\footnotetext{
172 Douglas Clark, "Crisis Hour for Premier," Daily Express, September 10, 1962; Douglas Clark. "Dief Sounds Warning," Daily Express, September 11, 1962: Douglas Clark, "The Accusers," Daily Express. September 12, 1962.

${ }_{173}$ "The Magnificent Answer," Daily Express, September 13, 1962; Douglas Clark, "No, No, No Again," Daily Express, September 18, 1962; "Arrogance and False Claims," Daily Express, September 18, 1962; Douglas Clark and Alexander Kenworthy, "Spell It, Please," Daily Express, September 19, 1962.

177 "An Election Must Decide," Daily Express, September 17, 1962.

175 "This Crisis Cannot Be Hidden," Daily Express, September 19, 1962.
} 
political parties. ${ }^{176}$ True Britons, the Express concluded, would not allow Macmillan to destroy their inheritance and their future.

The question remained as to whether an alternative to the Common Market existed. The Canadian Prime Minister believed that Britain should not neglect the possibilities afforded by continental Europe and that the expansion of Commonwealth trade would ensure Britain's continued world presence, protect Commonwealth interests and strengthen Britain. ${ }^{177}$ Diefenbaker had worked out a detailed alternative to the EEC, based primarily on plans for world- wide cooperation and the extension of free markets. ${ }^{178}$ Diefenbaker and Menzies both wished to have another conference to discuss the Common Market after the negotiations in Brussels concluded. ${ }^{179}$ The Daily Express claimed that the Commonwealth might offer an alternative that was more attractive to the British public than the Common Market, and that consequently Macmillan did not wish to risk possible embarrassment or further public opposition to his policies by permitting such discussions. ${ }^{180}$

The prospect of public discontent in the face of Commonwealth displeasure was a real fear for Macmillan since the public imagination revealed considerable emotional attachment to the ideas of Empire and the view of the Commonwealth as a community of

${ }^{176}$ Douglas Clark, “’Odd Man Out’ Uproar," Daily Express, September 17, 1962.

177 Library and Archives Canada, External Affairs, Canadian Papers Prepared for Prime Ministers' Meeting September 1962, volume 1, File \# 50084-K-40, volume 2, "British/EEC Negotiations: An Alternative to British Entry"; Patrick Keatley, "Major Task Faces Mr Macmillan," Guardian, September 8, 1962; Frances Moir, "Dief Keeps Them Guessing," Daily Herald, September 8, 1962; "Canadians Puzzled by 'Alternatives'," The Times, September 11, 1962.

${ }_{178}$ Library and Archives Canada. External Affairs, Canadian Papers Prepared for Prime Ministers' Meeting September 1962, volume 2, File no. 50084-K-40-6, "Commonwealth Prime Ministers Meeting: Memo FM PRIMDEL."

179 "Premier Lists EEC Benefits," Guardian, September 5, 1962; Patrick Keatley, "Major Task Faces Mr Macmillan," Guardian, September 8, 1962.

8. 1962.

${ }^{180}$ Douglas Clark, "It's Tough! Empire Men Seek Second Conference," Daily Express, September 
like minded citizens, united by blood and history. The Daily Mirror clearly recognised that public perception was easier to influence by appeals to tradition and national sentiment, than by rational appeals based on economic necessity. The pro-European Mirror feared, for example, that Commonwealth leaders would claim that "blood is thicker than water," reminding Britons that many Commonwealth citizens were originally settlers from Britain. ${ }^{181}$ They would also emphasise the Commonwealth's shared history, particularly the sacrifices made during the two World Wars. ${ }^{182}$ The newspaper believed, however, that this line of argument obscured the benefits of British involvement in continental Europe. Supporters of the Common Market, therefore, found themselves in a public relations battle to convince the British people that their future lay in Europe, rather than with the Commonwealth. In reporting on one pamphlet published by the Common Market Campaign, the Guardian emphasised the claim that many Britons assumed that the Commonwealth "retains the tightly-knit features of the Empire,"183 but it reminded its readers that imperial preference was a "dead letter." 184 The Guardian pointed out that the Commonwealth leaders had gone to great lengths to ensure that they were not associated with the old ideas of Empire and that they had deliberately avoided the "bearhug embrace of Lord Beaverbrook or any of the other 'anti-marketeers'." ${ }^{185}$ The Guardian held that the Commonwealth was a community of independent nations which had outgrown its imperial roots and the British public needed to outgrow its sentimental attachment to past imperial glories.

\footnotetext{
${ }^{181}$ Cassandra, "Thicker Than Water," Daily Mirror, September 7, 1962.

182 Ihid.

183 "More World Influence in EEC." Guardian, September 8. 1962.

184 Ibid.

${ }^{185}$ Keatley, "Major Task Faces Mr Macmillan."
} 
The Daily Express, as a committed defender of Britain's traditional imperial alignment, chose to emphasise through words and images the strength of the Commonwealth position and the weakness of that occupied by Prime Minister Macmillan. In its battle against the Common Market, the Express used political cartoons regularly, but during the week of meetings, it usually published at least two per issue: one on the front page and one on the editorial page. The extensive use of visual elements reveals fundamental assumptions about the pictures that would resonate with the British public. Predictably perhaps, nationalistic images reflecting Britain's past were preferred. The repeated depiction of Britannia, incidents from British imperial history and notable figures reinforced their significance for the British public. The Daily Express skilfully employed its cartoonists as an integral part of its battle to reaffirm the imperial basis of British national identity. The campaign began September 10, 1962 with the return of Michael Cummings from his summer holiday.

Cummings's opening salvo shows Macmillan on horseback galloping towards de Gaulle and Adenauer, who stand behind a multi-barrelled gun turret. Macmillan wields a broken sword and holds a "Europe or Bust" flag held high over his head. Behind him the Commonwealth, Labour Party and Public Opinion flee the shells fired by de Gaulle and Adenauer: Europe brings destruction and they sensibly have turned the other way, while the foolhardy Macmillan plunges on into the teeth of the guns. 
Figure 7 Daily Express, September 10, 1962

The imagery in the cartoon is impressive. The Charge of the Light Brigade is suggested by the Hussars' shakos and cavalry charge, while de Gaulle's comment, "C'est magnifique, mais ce n'est pas la guerre," was that which was originally uttered in the aftermath of the charge by the French Marshal, Pierre Bosquet. In a lesser known comment, but one which Cummings's readers may well have been aware, Bosquet had added: "C'est de la folie." Equally, many readers would have known that Lord Raglan, who had fought at Waterloo, habitually referred to his French allies in the Crimea as 'the enemy'. The Maginot line is invoked by the image of the gun turret, which also echoed the Russian guns at Sevastopol and which might be taken to imply that the French were on the defensive and were looking after themselves. The destruction of two world wars is suggested by the density of the shell fire and the cratered ground. Britain had fought these wars to preserve itself, and Europe, from Russian and German tyranny. The implication is that were Britain to join the EEC, it would be swallowed up and forced to revolve about the exclusive Franco-German axis. The cartoon asks why the Prime Minister (as the cartoon implies an honourable and brave man) would lead the country in a direction that 
threatened its survival. ${ }^{186}$ The successful reading of the cartoon relies heavily upon a broadly shared historical knowledge, which would render the images immediately recognisable. The common understanding of these events speaks not only to a sense of community but also of a national identity marked by its difference from a treacherous European 'Other' represented by de Gaulle and Adenauer.

As September progressed, the Daily Express became more explicit in its discussion of British national identity vis-à-vis Europe. By the end of the month, Cummings's cartoons regularly and clearly displayed Macmillan, as a European. Most often, he is dressed as a Frenchman or a German, in stark contrast to the Labour leader, Hugh Gaitskell, who remained a true Briton through his continued commitment to the Commonwealth. Gaitskell, not Macmillan is the only political leader who could be trusted not to betray Britain.

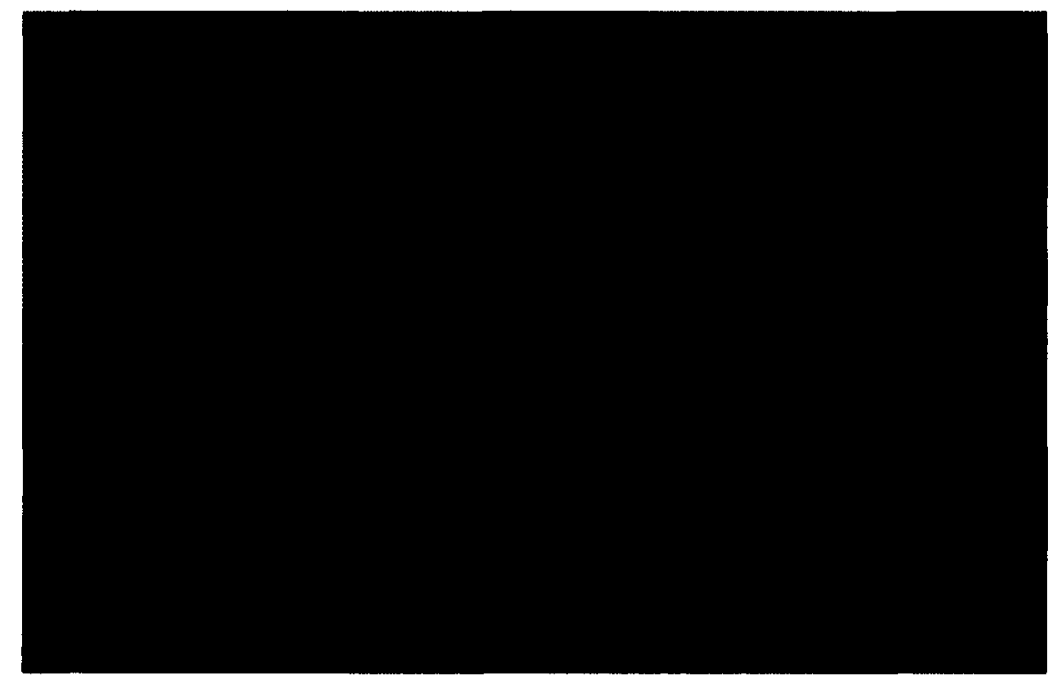

Figure 8 Daily Express, September 25, 1962

${ }^{186}$ Macmillan, who served in the Guards in the First World War, was wounded three times and known for his bravery. He won the Military Cross. H. C. G. Matthew, "Macmillan, (Maurice) Harold, first earl of Stockton (1894-1986)," Oxford Dictionary of National Biography, Oxford University Press. 2004; online edn, Jan 2011, accessed November 14, 2011, http://www.oxforddnb.com.proxy.library.carleton.ca/view/article/40185. 
These ideas were aptly demonstrated in a cartoon from September 19 that addressed Gaitskell's demand that Macmillan consult the British public before proceeding with his European policy. In rejoinder, Macmillan, dressed in lederhosen, clogs and a beret, replies "But, Mr Gaithers - I hope you're not going to suggest anything so Continental, so un-British, as asking the electorate to say 'Yes' or 'No' ..."

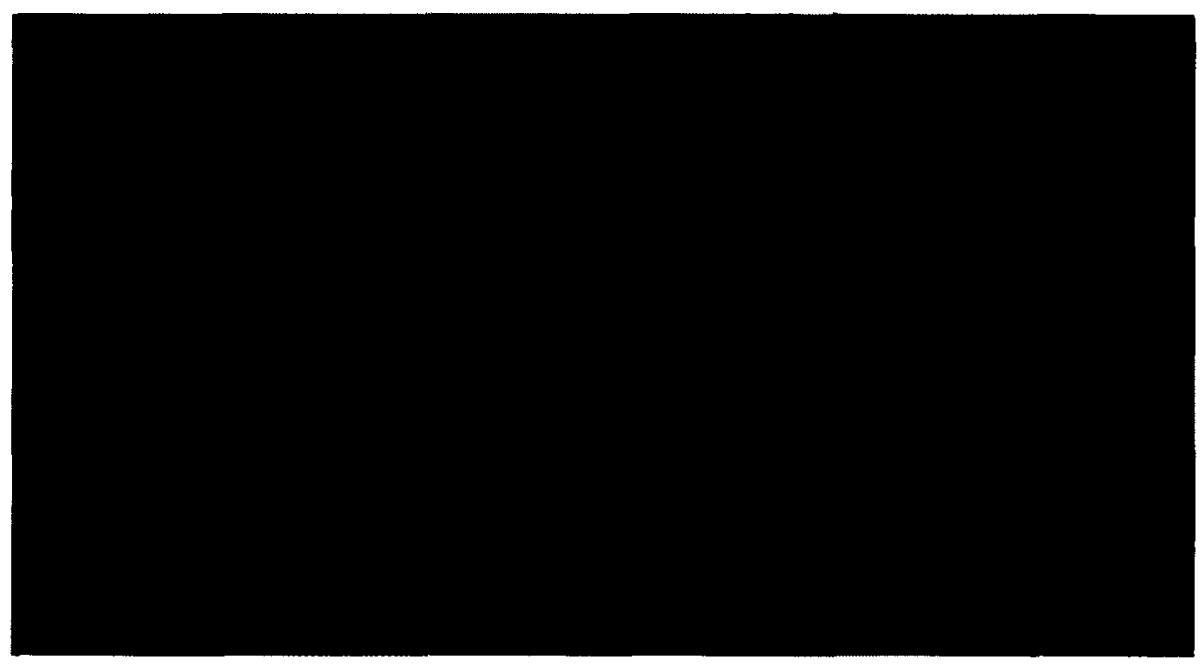

Figure 9 Daily Express, September 19, 1962

The reader, however, would realize that it was not Gaitskell who was un-British. By dressing Gaitskell as Britannia, Cummings implied that he embodied the spirit of Britain. Macmillan, with his French, German and Dutch clothing, his cigarette, bread and wine had clearly gone 'continental.' The cartoon implied that in his haste to make Britain 'European,' Macmillan was prepared to sacrifice not only Britain's political independence, but also its very identity. Cummings warned readers to guard the fundamental components of Britishness, including the Commonwealth.

British newspapers disagreed on what constituted Britishness, and whether Britain should be a European nation, an Atlantic nation, or a hybrid. The Daily Mirror believed that redefining Britain as European offered the best possible future. The newspaper pointed out that Britain's youth supported the Common Market, because it offered 
tremendous opportunities. ${ }^{187}$ After all, "The country is full of young people wanting to go places... The best way for them to use this ability is to apply British genius in influencing Europe peacefully... What right have people of my generation to deny them this chance?"188 The older generation had benefitted from Britain's imperial era. Now that the Empire was disappearing, Britain needed to embrace a new era to allow youth the same advantages. If Britain stayed out of the Common Market, it faced isolation, a possible third world war and a Europe characterised by conflict. If, however, Britain joined the Common Market, the results would be progress, a peaceful Europe and cooperation. ${ }^{189}$ Echoing Macmillan, the newspaper claimed that Britain's past isolation from Europe had led to the conflicts of the past few decades; now the country was in decline, only the potential of Europe could restore Britain's fortunes.

The Daily Mirror repeatedly insisted that Britain's future lay in Europe, not in the Commonwealth. ${ }^{190}$ The newspaper explained that the Commonwealth had changed from an empire into a freer association where every member had to stand independently. ${ }^{191}$ After all, Britain could not be expected to continue in its role as the Commonwealth's "rich uncle" after losing its pre-eminent place in world affairs. ${ }^{192}$ Its use of language revealed the Daily Mirror's resentment of the Commonwealth. The newspaper had begun its campaign to convince Britons that their future lay in Europe in the mid 1950s, but Britons maintained a firm emotional attachment to the Commonwealth and regarded its survival as being threatened by European integration. The newspaper repeatedly

187 "This is Why I Spoke Out for the Common Market," Daily Mirror. September 10, 1962.

188 Ibid.

189 "Who Dare Say the Price is Too High?" Daily Mirror. September 11, 1962; Victor Knight and Gordon Jeffery, "Mac Speaks Out to the Premiers," Daily Mirror, September 11, 1962.

190 "Who Dare Say the Price is Too High?" Daily Mirror, September 11, 1962.

191 “Why Britain, Alone, Must Decide," Daily Mirror, September 13, 1962.

${ }^{192}$ Ibid. 
insisted that the Commonwealth would evolve, but not disappear, in hopes that with these assurances the public would be more open to the Common Market. ${ }^{193}$

The Mirror, downplayed the conflict between the British government's European policy and the Commonwealth, claiming that the two sides remained friendly, although there was some tension over the terms of membership and all agreed that the final decision would be Britain's. ${ }^{194}$ The Commonwealth leaders were anxious, but their anxiety reflected their own domestic difficulties and fears (some of which the Daily Mirror clearly believed were imagined). ${ }^{195}$ This was aptly demonstrated in a cartoon from September 13, 1962. The Commonwealth leaders were shown waving clouds and pouring water from a hose in front of a doorway, masking Macmillan's view of the bright, sunny day.

Figure 10 Daily Mirror, September 13, 1962

${ }_{193}^{103}$ Ibid.

194 "A Market Challenge to Mac," Daily Mirror, September 12, 1962; Victor Knight and Gordon Jeffery, "Market: Call for Better Terms," Daily Mirror, September 12, 1962.

195 “Exposing the Bogus Clain," Daily Mirror, September 14, 1962. 
The cartoon implied that the Commonwealth leaders hoped to dissuade the Prime Minister from venturing forward, but he ought not to be deceived by their arguments. The Daily Mirror was confident that the interests of Britain and of the Commonwealth could be combined and that a compromise was possible. ${ }^{196}$

The Daily Mirror however, was not entirely optimistic in its outlook. It argued that the real threat to both Britain and the Commonwealth was a refusal to embrace postwar change. Franklin's September 19, 1962 cartoon deftly captures this concern. Britain, portrayed as a young business man, is caught in the beards of the "Outworn Ideas and Past Era Brigade." Three old men are seated in a Bath chair covered in cobwebs, fastened to a large anchor in the sand. Moths circle around their heads. The men are dressed as an imperial adventurer (possibly Livingston), Victorian gentleman (possibly Salisbury) and a medieval knight (the Daily Express's proprietor, Lord Beaverbrook). Their beards encircle the foot of the young, energetic British businessman, but Macmillan is running to the rescue. Dressed as a barber (labelled "Common Market Drive"), he offers to cut Britain free, from the strangle hold of the past and to let the "youth advance to the frontiers of the future." A stark warning is embedded in this cartoon: Britain must decide whether to accept economic freedom or to remain chained to the past.

196 Rhodesia had become an enthusiastic supporter of the Common Market and other African countries were seeing the wisdom in Macmillan's policy. A communique was in reach that would not hamper British negotiations in Brussels. Even those who remained doubters were being more constructive in their feedback. The newspaper was confident that a compromise was possible. Victor Knight and Gordon Jeffery, "I back Mac on Market, Says Sir Roy," Daily Mirror, September 13, 1962; Victor Knight and Gordon Jeffery, "Mac Rallies Market Doubters," Daily Mirror, September 14, 1962; Victor Knight and Gordon Jeffery, "Mac: Big Speech on Monday," Daily Mirror, September 15; Willian Greig, "Market: Now It's All Up To Mac," Daily Mirror, September 15, 1962; "Mac Faces the Last Big Hurdle," Daily Mirror. September 18, 1962; “Mac Won't Be Tied," Daily Mirror, September 19, 1962. 
Figure 11 Daily Mirror, September 19, 1962

The Guardian agreed that Britain's future lay in Europe. According to this newspaper, Britain belonged in the EEC because it was a European nation. ${ }^{197}$ European integration would weaken Commonwealth links and Britain would, inevitably, be drawn into a political union. ${ }^{198}$ This political union would allow Britain to exercise influence in and through Europe, and lessen the chance of European war. The Guardian believed that Macmillan made a good case for Britain's need to join the EEC in order to maintain influence and economic power, but that he neglected to deal with the real impact of the Common Market. ${ }^{199}$ The Guardian held that the public required education about the need for deeper integration within Europe since the world was changing and larger political blocs would be necessary in order to compete with the superpowers, the United States and Soviet Union. The newspaper believed that many of the elite were convinced

107 "Gains and Losses in Europe," Guardian, September 19, 1962.

198 "The Decision," Guardian, September 17, 1962.

199 "The Reality of Consultation," Guardian, September 15, 1962. 
that Britain needed to join the EEC, but the general public was not. ${ }^{200}$ If the Prime Minister hoped to join the Common Market, he would need to persuade Britons that the EEC offered a great future. ${ }^{201}$

Like the Guardian, The Times suggested that political integration was inevitable, but was unsure as to how far this merger would go. ${ }^{202}$ The newspaper was also not convinced that Britain was a European nation. It reminded Britons that there were fundamental differences between Britain and continental Europe. Continental Europeans had been ravaged by war and occupied by foreign countries which had affected their sense of identity. Britain still maintained its identity based on a world community centred on the Commonwealth. Britain's future influence in Europe would depend on how far it was willing to integrate. ${ }^{203}$ While Britons should not expect to be able to take control or to lead Europe, they would be crucial in containing de Gaulle's dictatorial style. The Times suggested that Britain could thus maintain its tradition of protecting the underdog and help mould a Europe that was economically and politically liberal, while maintaining the Atlantic economic association which would balance world economics. ${ }^{204}$ Britain's role would not be "a question of 'stepping into leadership' or 'taking over the helm'...Britain would be welcomed in by many in Europe for almost the opposite reason." 205 Britain would once again ensure that Europe was not dominated by one nation, although the newspaper did question whether de Gaulle would allow Britain to

\footnotetext{
${ }^{200}$ Lord Altrincham, "Macmillan's Next Task," Guardian, September 13, 1962.

201 "Who Dare Say the Price is Too High?" Daily Mirror, September 11, 1962.

202 "Tomorrow's Europe," The Times, September 13, 1962.

203 Ibid.

204 "Striking the Balance," The Times, September 10, 1962.

205 "Tomorrow's Europe," The Times, September 13, 1962.
} 
join the Common Market. Still, The Times believed that Britain must take advantage of the opportunities promised through membership in the Common Market.

The Daily Express believed that no amount of influence in Europe was worth the loss of the Commonwealth. The sacrifice of the Commonwealth was a continuous theme in the Daily Express's warnings about the Common Market, second only to the newspaper's fears that the Commonwealth would be destroyed. The Daily Express highlighted an opening Conference speech by the Jamaican Prime Minister, Sir Alexander Bustamante, on how the Common Market would affect Britain and the Commonwealth. British policy, he stated, was "like a surgeon's knife thrust into the body of the Commonwealth, cutting off one member from another, dividing one friend from another." ${ }^{206}$ Since the Daily Express believed that the Commonwealth formed an integral component of Britain, its destruction was unthinkable. By taking the country into the EEC and thereby destroying the Commonwealth, Macmillan would destroy Britain.

In 1962, Commonwealth links were not just emotional. The Guardian ridiculed other newspapers, particularly the Daily Mirror, for ignoring the Commonwealth's legitimate concerns. ${ }^{207}$ The Commonwealth's centrality to national identity made it impossible for British politicians to ignore. National identity relates back to the belief that members of a nation are members of a community. This sense of community is not bound by locale. National identity is not necessarily defined by a geographic region, but by a shared sense of community. In 1962 , Britons continued to believe in a British community embodied in the Commonwealth.

\footnotetext{
${ }^{206}$ Douglas Clark, "Moment of Truth," Daily Express, September 13, 1962.

207 "The Reality of Consultation," Guardian, September 15, 1962.
} 
The argument that the Commonwealth formed an integral part of British national identity was also found in the Daily Express. No policy, therefore, that threatened the Commonwealth should be considered as its loss would mean "the whole English way of life [would] be in danger." ${ }^{208}$ The Daily Express made its case using emotional nationalistic appeals and interviews with patriotic Britons. The last living winner of a V.C. and bar, Captain Charles Upham, claimed that the Commonwealth was a "living testimony to all the labours of our ancestors in casting a girdle round the globe from this little island. In these Prime Ministers we saw our Empire history made flesh and personified. All the brainpower and pioneering exertions of the British stock were here, identified." 209 The British nation was not confined to the island of Great Britain, but rather it had spread throughout the world, existing wherever these shared values were manifest.

The idea of a 'greater Britain' was featured in the Guardian's series of articles on Australia and New Zealand. Published during the Commonwealth Conference, the articles were written by James Morris, a contributor to the newspaper, who was on an extended trip in the South Pacific. According to Morris, except for the fact that it was thirteen thousand miles away, New Zealand might very well be part of the United Kingdom. His work emphasised the strong cultural links between Britain and New Zealand. It appeared to Morris, that New Zealanders lived as their ancestors had done in

\footnotetext{
208 "Double V.C. Pleads: DON'T do it!" Daily Express, September 14, 1962.

${ }^{204} \mathrm{lbid}$. Upham was originally from New Zealand. His obituary in the Daily Telegraph reads: "In 1962, he was persuaded to denounce the British government's attempt to enter the Common Market: 'Britain will gradually be pulled down and down,' Upham admonished, 'and the whole English way of life will be in danger.' He reiterated the point in 1971: 'Your politicians have made money their god, but what they are buying is disaster.' He added: 'They'll cheat you yet, those Germans." "Captain Charles Upham VC \& Bar," Telegraph. November 23, 1994.
} 
Britain fifty years before. ${ }^{210}$ While politically independent, "in other respects [Morris wrote] she is frankly one of us." ${ }^{211}$ Morris reported that going to New Zealand made the Commonwealth real. Any threat to the Commonwealth, he believed, would be a disaster for both the "distant daughter" and the "metropolitan mother." 212 Moreover, according to Morris, New Zealanders' Britishness was more than skin deep.

In a rather extraordinary throwback to the language of eugenics, Morris claimed that the "dividing line between a Briton and a New Zealander is almost non-existent" and that a "New Zealander's head is still the same shape as ours...and we unmistakably share a blood group. ${ }^{.213}$ For Morris, culturally and racially, the two nations were part of a greater whole. ${ }^{214}$ Morris was hit by "qualms of conscience or conviction as our painful progress into Europe seems to alienate us, clause by clause, from this pleasant alter ego in the South." ${ }^{215}$ Britain had exported its civilisation through its imperial activities. While the other settler colonies had grown away and were looking to forge their own identity, New Zealand stood as a reminder that at their heart, Australia and Canada were also British civilisations. ${ }^{216}$ This belief that all subjects, or at least all white subjects, of the Empire were British was a dominant feature of British national identity. Indeed, in the

210 James Morris, "Britain's Alter Ego in the South," Guardian, September 21, 1962.

211 James Morris, "Testiness in the New Zealand Air," Guardian, September 22, 1962.

212 Morris, "Britain's Alter Ego in the South."

213 Morris, "Testiness in the New Zealand Air."

214 Ibid.

215 Morris, "Britain's Alter Ego in the South." The article does not refer to any specific group in Britain, labelling all Britons with a similar brush.

${ }^{216}$ Morris, "Testiness in the New Zealand Air." Morris published a three part history of the British Empire in the late 1960 s and 70 s, revealing a more critical view of Britain's imperial activities. James Morris, Par Britannica: The Climax of an Empire (New York: Harcourt. Brace \& World, 1968); James Morris, Heaven's command: An Imperial Progress. (London: Farber, 1973); James Morris, Farewell the Trumpets: An Imperial Retreat (London: Faber, 1978). He subsequently underwent sexual reassignment surgery and published as Jan Morris. Stephen Constantine, "British Emigration to the EmpireCommonwealth since 1880: From Overseas Settlement to Diaspora?" in Carl Bridge and Keith Fedorowich, eds. (London: Frank Cass, 2003), 16. 
1970s, it was still possible for a British subject resident in Ontario, but not a Canadian citizen, to vote in provincial elections. ${ }^{217}$ Morris believed that Australia, New Zealand and Canada would remain inherently British civilisations, even if official Commonwealth links dissolved; while Britain might not be in political control of a vast Empire, its legacy would still constitute a major force in world affairs.

Even those inhabitants of Commonwealth countries who were of other nationalities had become British. For example, Roy Welensky was Polish, but had become more British than most Britons describing himself as "half-Jewish, halfAfrikaner, but 'a hundred per cent British'."218 The Commonwealth countries were British, bound by the English language and by British traditions and institutions. Taxing Commonwealth goods was unthinkable for "it would be just as suitable for England to tax Scottish beef, or for Surrey to put a duty of 25 per cent on Yorkshire pudding." ${ }^{219}$ To the Daily Express, the members of the Commonwealth were as British as Scotland or Wales.

The belief that the Empire had created a British community that differed fundamentally from the Continent was well established. Macmillan's European initiative was an abrupt change in a three hundred year old British policy. The Prime Minister might be European minded, but the newspaper insisted that Britons were not. ${ }^{220}$ In one article, the Daily Express quoted extensively from Sir William Teeling, a Conservative

\footnotetext{
${ }^{217}$ British subjects lost the ability to vote in Canadian elections in 1975. Rand Dyck, Canadian Politics, $5^{\text {th }}$ edition (Toronto: Nelson, 2009). 181.

218 Donal Lowry, "The Crown, Empire, Loyalism and the Assimilation of Non-British White Subjects in the British World: An Argument Against Ethnic Determinism," in The British World: Diaspora, Culture and Identity, eds. Carl Bridge and Keith Fedorowich (London: Frank Cass, 2003), 114; "Double V.C. Pleads: DON'T do it!" Daily Express, September 14, 1962.

219 "Double V.C. Pleads: DON'T do it!" Daily Express, September 14, 1962.

${ }^{220}$ Alexander Kenworthy, "Our Future by Macmillan," Daily Express, September 18, 1962.
} 
Member of Parliament: "We have always spread out into Asia, Africa and America. I begin to wonder whether Mr. Macmillan is not in grave danger of becoming a second Lord North, who lost us the United States because he would not see the danger signals. Now we are in danger of the Commonwealth breaking up."221 According to the newspaper, Britain's destiny had always lain in overseas adventures, not in continental Europe. After all, Britain had historically looked to the sea, not to Europe. The Daily Express agreed with Sir Arthur Bryant's claim that Britain was not a European island: "historically we sprang from Europe, but historically we also belong far more today to those ocean nations we helped to found; including the United States."222 Britain's most important connections lay in its imperial legacy, not in geographic proximity to Europe.

The Daily Express believed that the British public continued to place greater importance on Commonwealth relations than the Common Market. The newspaper claimed that the Commonwealth was beginning to realise that while Macmillan might support the Common Market, Britain did not. ${ }^{223}$ The majority of Britons placed a high priority on the Commonwealth and would not consider accepting a policy that threatened its survival. ${ }^{224}$ The Daily Express delivered a withering and colourful verdict on the proMarket press, describing those who supported the Common Market as "baboons," a "mad army" or "elderly and unskilled" while ridiculing a music critic who insinuated that

221 "This Dreamer by a Tory M.P.," Daily Express, September 18, 1962.

222 "Sir Arthur Calls for Election," Daily Express, September 19. 1962. Bryant wrote extensively during the post-war period. His writings mostly consisted of patriotic history that extolled Britain's glorious past. He was a household name in the 1960s. Richard Griffiths, 'Bryant, Sir Arthur Wynne Morgan (1899-1985)', Oxford Dictionary of National Biography, Oxford University Press, 2004; online edn, Jan 2011, accessed July 22, 2011, http://www.oxforddnb.com.proxy.library.carleton.ca/view/article/ 30867.

223 "Challenge to the Tories," Daily Express, September 10, 1962.

224 "The Hour of Decision," Daily Express, September 12, 1962. 
"Land of Hope and Glory" and "Rule Britannia" were out of place in a modern Britain. ${ }^{225}$ These statements were an exaggeration based on statements taken completely out of context. The Daily Mirror had stated that because Britons had not been told about the Common Market, they were like uneducated baboons. Nonetheless, the statements offered great propaganda value. This language was highly insulting, and indicative of the press' patronising attitude towards the British public. The impression the Daily Express cultivated was that it alone respected Britons.

The Commonwealth Prime Ministers' Conference concluded with the publication of a communique on September 19, 1962. The official report of the conference's results, focused primarily on the discussions over British membership in the EEC. The tense atmosphere resulting from "differences of viewpoint and many uncertainties" was acknowledged, but the communique took care to insist that "all the exchanges [had] been conducted in the frank and friendly atmosphere which characterise[d] Commonwealth meetings." 226 Press coverage of the official report of the Conference varied to the point where a reader of several different newspapers might be forgiven for believing that the contents differed widely. ${ }^{227}$ Predictably, the two newspapers that diverged the most were the Daily Express and the Daily Mirror. The Daily Express interpreted the Conference as a major defeat. Cummings's editorial cartoon portrays a battered and bruised Macmillan hiding his wounds behind a mask entitled "Communiqué". The Prime Minister might believe that he would be able to fool the public with polite language and reassurances, but

\footnotetext{
225 "Arrogance and False Claims," Daily Express, September 18, 1962.

${ }^{226}$ Conmonwealth Prime Ministers' Meeting 1962 Final Communiqué (London: Her Majesty's

227 Three newspapers published the Communique in full: the Daily Express, the Guardian and The
} Stationary Office, 1962). 3. Times. 
the truth was much uglier. Macmillan had tried to bully the Commonwealth, and it had fought back. He would have to live with the consequences.

Figure 12 Daily Express, September 20,1962

Macmillan was fiercely criticised in the Daily Express's coverage of the Communiqué. The British Prime Minister had deluded himself that the Commonwealth Prime Ministers approved his European policy, but the Communiqué was really just a "restatement of sharply clashing views."228 The Daily Express claimed that Commonwealth leaders were leaving as they arrived, hostile or disturbed, with twelve out of the fifteen Prime Ministers having failed to approve of the pro-market section of the Communiqué. $20,1962$.

${ }^{228}$ Douglas Clark and Alexander Kenworthy, "'Keep Fighting Plea," Daily Express, September 
According to the Daily Express, the public would ultimately hold the Prime Minister accountable to his pledges and was, indeed, fast losing patience with his meanderings. Commonwealth leaders were "nearer to the thinking of the mass of the British people than" Macmillan, as the public did not believe that the Commonwealth could be "shrugged off or thrown lightly into the discard." 229 The Prime Minister might believe that Britain's future lay in Europe, but the public knew that the Commonwealth was central to the nation's continued strength. The cultural and emotional bonds with the Commonwealth were too important to be thrown away; in fact, the newspaper believed that "this conference ha[d] strengthened, not weakened, their faith in the Empire."230 For the Daily Express, the Commonwealth and the Empire were still foundational to British national pride and identity. The people would not stand idly by and allow Macmillan to destroy Britain's heritage. The newspaper exploited every opportunity to reinforce its interpretation of national identity, exhorting its readers to remember the glory of the British Empire.

The Daily Mirror interpreted the Communiqué quite differently as was aptly demonstrated in Franklin's editorial cartoon of September 21. It showed Macmillan driving away from a filling station (representing the Commonwealth Conference) with Heath as a passenger. Macmillan explains to Heath that they can now head back to the open road which is indicated by a sign that reads "Common Market". John Diefenbaker and Robert Menzies stand by the pump and Roy Welensky holds the hose after filling up Macmillan's car. The Commonwealth leaders had given the Prime Minister the 'Go Ahead', tempered by a warning to drive carefully. The British, however, still face a road

\footnotetext{
229 “The Struggle Goes On," Daily Express, September 20, 1962.
} 
block; around the corner, de Gaulle was seen digging up the road leading to the Common Market. While Macmillan and Health had successfully navigated Commonwealth opposition, they still faced French resistance to British membership in the EEC. The cartoon strongly implies that Britain could not have continued on the road to the EEC without the support of Commonwealth leaders. Even as Britain prepared for its new role in Europe, its imperial past proved a vital part of its present.

Figure 13 Daily Mirror, September 21, 1962

The Daily Mirror was relieved to report that Commonwealth relations had stabilised. ${ }^{231}$ The Daily Herald agreed with the Daily Mirror that Macmillan had won a victory at the Commonwealth meetings, but believed that it had been difficult and costly.

${ }^{231}$ Gordon Jeffery, "Go Ahead!" Daily Mirror, September 20, 1962. 
The British Prime Minister emerged victorious, but badly bruised. ${ }^{232}$ While the Commonwealth leaders would not oppose British membership in the EEC, they clearly had not embraced the Common Market. In fact, many of the Commonwealth leaders continued to believe that the negotiated terms were unacceptable, a view which was shared by Hugh Gaitskell and a growing contingent of the Labour Party. ${ }^{233}$ Fears that the Commonwealth would be irrevocably damaged by the Common Market had not been allayed. There was growing concern in the Commonwealth and at home that British participation in Europe might come at too high a price. The Daily Herald cautioned that the consequences of the Commonwealth Conference remained unknown. ${ }^{234}$ The newspaper believed that the Commonwealth retained a prominent position in the British public's imagination although the economic and political links had weakened significantly since the heyday of Empire. The Daily Herald suspected that the annual political party conferences, scheduled in October 1962, would reflect growing public misgivings about the Common Market. ${ }^{235}$

The Guardian concurred that the true results of the Commonwealth Conference would not be known until the Labour Party and Conservative Party held their annual meetings in October. ${ }^{236}$ The newspaper pointed out that debate over the Common Market was fast becoming a political battle between the two parties, and revealed a fundamental divide in British society over the country's future role in Europe. Joining the EEC would

232 David Watt and Francis Moir, "Proceed - With Care," Daily Herald, September 20, 1962. This article's title is almost identical to the message in Franklin's cartoon, illustrating the common message of both the Daily Herald and the Daily Mirror.

${ }^{233} \mathrm{Ibid}$.

${ }^{234}$ Ibid.

${ }^{235}$ Furthermore, Parliament had broken for the summer recess on 3 July and only returned on 25 October so the upcoming annual conferences represented the first opportunity for members of the two political parties to discuss the Commonwealth and the Common Market following the Conference.

${ }^{36}$ R.H.S Crossman, "Secret Weapons," Guardian, September 21, 1962. 
indicate that Britain was fundamentally rearranging both its European policy and international role.

According to the Guardian, the decision about entry into the Common Market would be made by most Britons on the basis of instinct and emotion, not economic facts. $^{237}$ The public would have to decide whether they were willing to accept a new interpretation of British national identity. According to the newspaper, the public had to carefully consider the following questions:

Where do Britain's immediate duty and destiny lie? Where do we belong? What are the relative values of Western Europe and the Commonwealth as living organisms, as meaningful communities, claiming our allegiance?... The answers to these questions cannot be handed to us on a plate by any non-party group of economists and statisticians. We must look for them in our hearts, with such honest and patient help as our heads can provide. ${ }^{238}$

As the Guardian stated, the heart of the debate over the Common Market was the question of what it meant to be British. Britons needed to decide whether their identity and destiny were tied to the Commonwealth or to Europe. This decision would be difficult and highly personal, reflecting each individual's interpretation of the situation. The Commonwealth maintained a great emotional appeal for the public, a visible reminder of the Empire's glory and prestige. Indeed, the Guardian emphasised that the government needed to remain cognisant of this emotional attachment in its attempts to persuade the public to support its European policy. The Guardian was convinced that the Commonwealth would eventually give Britain's Common Market plans a green light but, 1962.

${ }^{237}$ Lord Altrincham, "The People's Voice: Approving Britain's Entry," Guardian, September 20, ${ }^{238}$ Ibid. 
as the paper stated, for now the leaders had "firmly fixed at amber."239 Macmillan would need to ensure that there was increased consultation with Commonwealth countries as the negotiations continued.

The Commonwealth Conference also necessitated a public response from the government. On September 20, 1962, Macmillan gave a televised speech to allay public concern over the Commonwealth and Common Market. His words were intended to reassure Britons that the Common Market was not a threat to the Commonwealth. The press coverage of the Conference had emphasised the divisions within the Commonwealth; the public had to be reassured that the Commonwealth was not in danger of disintegrating over the Common Market. Macmillan's speech was also intended to inform the British people about the changing nature of the Commonwealth and how these changes affected Britain's international position.

Macmillan explained that the Commonwealth had been composed of countries that had a common vision based on shared traditions and heritage, but this was no longer the case. After the Second World War, the Commonwealth had been British; now it was made up of many cultures and races. ${ }^{240}$ The strength of the Commonwealth might be its diversity, but this meant that it was no longer an exclusively British institution. Commonwealth leaders had expressed their reservations about British membership in the EEC because they feared that the Common Market would fundamentally change the association. Macmillan admitted that this fear was based in reality, but posited that

\footnotetext{
${ }^{239}$ Patrick Keatley, "Premiers Reserve Judgment," Guardian, September 20, 1962.

240 Harold Macmillan, "Alternative to Six Not a Practical Position," Television Address, September 20, 1962 in The Times, September 21, 1962.
} 
perhaps change was necessary. ${ }^{241}$ After two wars the world had changed; it was now time for Britain to embrace these changes. Britons should value their historic legacy, but not be constrained by it. Britain's future lay in Europe.

The Daily Mirror applauded the content of the Prime Minister's speech; finally, Macmillan was telling the British people about the Common Market and explaining that it represented both a challenge and an opportunity. ${ }^{242}$ Hostile to the Conservative Party, the Daily Mirror had difficulty reconciling the traditionalist image of the Prime Minister with his progressive policy. The newspaper supported Macmillan's policy, but struggled with his person, believing that he was a relic from the past. It described him as "a genial bloodhound, faintly Edwardian and politically musty," however, "he said the right things and obviously BELIEVED in the right things." 243 The paradox of an Edwardian gentleman advocating for a European future was difficult for the Mirror to reconcile. Still, the message was more important than the messenger; the Daily Mirror hoped that the public would finally begin to embrace a new vision for Britain.

According to the Daily Mirror, Britain was living in the past. Britons were enamoured with a legacy of greatness, but were unable to see that in order to remain a world power, the country needed to break free of its historical traditions and welcome change. ${ }^{244}$ The Daily Mirror used bold font and caps to highlight the Prime Minister's question: “ARE WE GOING TO LOOK FORWARD?" 245 This print emphasised the importance of looking to the future rather than remaining rooted in past

\footnotetext{
${ }^{241}$ Macinillan, "Alternative to Six."

242 "Looking Forward," Daily Mirror, September 21, 1962.

${ }^{243} \mathrm{Ibid}$.

244 Ibid.

${ }^{245}$ Ibid.
} 
accomplishments. The Commonwealth might have an emotional hold on the British people, but they should be concentrating on the opportunities offered by the Common Market rather than dwelling on past glories. ${ }^{246}$ European integration would mean sacrifices for Britain, but they would be worthwhile. The newspaper maintained that once all the facts were in, the practical nature of the British people would be revealed. They would support Europe, because it offered Britain the possibility of becoming an economic and political power once again.

The Times, Guardian and the Daily Herald all agreed that Britain's future lay in Europe, although they were not as willing to dismiss Commonwealth concerns as either the Daily Mirror or the Prime Minister. ${ }^{247}$ The Guardian and the Daily Herald believed that Macmillan had made a good argument for British entry into the Common Market. He had successfully argued that Britain did not need to choose between the EEC and the Commonwealth, but he had overstated his case in claiming that the member countries had been satisfied by the results of the Conference. ${ }^{248}$ Predictably, the Daily Express believed that Macmillan's speech had been a complete farce. The Prime Minister's speech was supposed to be an account of the Commonwealth Conference, but the newspaper claimed that after only three minutes, Macmillan had launched into a defence of his European policy. ${ }^{249}$ He was not interested in addressing the changing role of the Commonwealth, desiring only to get Britain into Europe as quickly as possible. For the Daily Express, the speech was evidence of Macmillan's complete lack of understanding

\footnotetext{
${ }^{246} \mathrm{Ibid}$.

${ }^{247}$ "A Lot to be Done Yet in Brussels," The Times, September 21, 1962.

248 "Gaitskell Replies to Premier Tonight," Daily Herald, September 21, 1962; "'Britain Will Decide," Guardian, September 21, 1962; "Our Voice in Europe," Guardian, September 21, 1962.

${ }^{249}$ Douglas Clark and Alexander Kenworthy, "But In the Background the Cry Grows - Let Voters Speak," Daily Express, September 21, 1962.
} 
of the Common Market and the Commonwealth. The Prime Minister claimed that membership in the EEC would preserve the power and strength of Britain, reflecting the common opinion that Britain would provide leadership to an integrated Europe. ${ }^{250}$ The Daily Express remained unconvinced that France and Germany would allow Britain to assume a leadership role, asking "how can Britain preserve her power by entering a community dominated by the Franco-German axis? How can she strengthen herself by becoming a junior partner?"251 The newspaper believed that Britain would be expected to play a role similar to the Benelux countries: although a full participant, true authority would rest with France and Germany. By accepting such an arrangement, Britain would be betraying the men who had died only a few years previous in order to ensure that Britain remained sovereign and independent. ${ }^{252}$

One section of the Prime Minister's speech was especially troubling to the Daily Express. Macmillan's claim that the Commonwealth was no longer a cohesive unit raised the newspaper's ire. According to the Daily Express, the Commonwealth countries might be divided by race and stage of development, but "they [were] united by a common language, by a great amount of common law and by common endeavour - in peace and war. The nations of the Commonwealth have fought together. The nations of Europe - divided from us by language, law and tradition - have fought against each other. And against us." ${ }^{253}$ The idea that Britain had more in common with Europe than members of the Commonwealth was unthinkable. To the Daily Express, the

\footnotetext{
${ }^{250}$ As previously mentioned, this argument was used extensively by both the Guardian and the Daily Mirror to argue in favour of British membership in the EEC.

${ }^{251}$ "No, Sir! The Case Has Not Been Made," Daily Express, September 21, 1962.

252 Ibid.

${ }^{253}$ Ibid.
} 
Commonwealth was a family. Drawn together by shared history, the member countries formed a community based on common values that grew out of British civilisation. The newspaper could not accept the position that economic ease could justify the betrayal of cultural brethren.

The Daily Express did not believe that it alone was horrified by such a possibility. In fact, it argued that Macmillan's speech had ignited "the mightiest political row of this parliament." 254 True Britons would be unable to accept the betrayal of the Commonwealth, and a great political battle was brewing. The Daily Express was convinced that Macmillan's policies would divide the Conservative Party and ultimately alienate the Prime Minister from his followers. Macmillan claimed that the decision about entry into the Common Market was Britain's alone. The newspaper agreed, but claimed that the decision should be made by the British people, not by a Cabinet or political party forced into compliance. ${ }^{255}$ The British people would not stand idly by and allow their greatest treasure to be destroyed. If Macmillan refused to protect the Commonwealth, then Britons would do so themselves.

The Daily Express was not the only one to interpret Macmillan's speech as a political attack. The Labour Party decided to exercise its right to respond, and Hugh Gaitskell addressed the nation on television the following evening. Foreshadowing many of the themes that would dominate his speech to the Labour Party's annual conference, Gaitskell replied to Macmillan's claims regarding the Commonwealth and the Common Market. His speech was deliberately ambivalent because the Labour Party remained

\footnotetext{
${ }^{254}$ Douglas Clark and Alexander Kenworthy, "But In the Background the Cry Grows - Let Voters Speak," Daily Express, September 21, 1962.

255 "No. Sir! The Case Has Not Been Made," Daily Express, September 21, 1962.
} 
uncertain. He reiterated that the Labour Party was unhappy with the current terms of membership ${ }^{256}$ and that they should be made a priority in future negotiations. Historically Britain had protected its dependencies. The Labour Party welcomed colonial independence, but continued to believe that Britain had a responsibility to ensure the Commonwealth's wellbeing. ${ }^{257}$

Labour's demand for better terms of entry had been an ongoing theme in the debate over the Common Market. Gaitskell forcefully criticised any attempt to limit British sovereignty through European integration, claiming that such an action would mean the end of Britain as a sovereign country. Britain would become "no more than Texas or California in the United States of Europe." 258 The choice of Texas and California as examples was deliberate. Both states had once been independent, but had surrendered their sovereignty to the United States. If the Common Market meant that Britain lost its ability to act independently, membership in the EEC was tantamount to surrendering sovereignty. This emotional statement was intended to provoke indignation in the public, igniting their national pride. Britain, the most powerful country in the world during the nineteenth century, could not allow itself to become subservient to a supranational institution.

Gaitskell's speech was greeted with great enthusiasm by the Daily Express. Claiming that his broadcast was the most effective use of British television by a politician, the newspaper applauded Gaitskell's ability to recognise that Macmillan was

\footnotetext{
256 “"Mr. Gaitskell Replies Must Ask Six For Precise Trading Agreements, Vague Assurances Not Enough For Commonwealth," The Times, September 22, 1962.

${ }^{257}$ Ibid.

${ }^{258}$ Ibid.
} 
offering a political challenge. ${ }^{259}$ The Daily Express believed that it finally had an ally in its battle against the Common Market. The newspaper portrayed Gaitskell as a devoted imperialist and praised "his faith in the Empire's immense influence for good in the world." 260 As leader of the Labour Party, Gaitskell saw a great distinction between the old British Empire and the Commonwealth. For the Daily Express, however, they were one and the same.

In the newspaper's eyes, the Labour Party was becoming the stalwart guardian of Britain's imperial past. This interpretation was vividly illustrated in a cartoon from September 22. An older gentleman, in Edwardian attire, is shown standing in front of a fireplace. The wall behind him features the emblems of Empire. Clearly this gentleman was a participant in Britain's imperial adventure. He holds two posters. On the left is Gaitskell, dressed as Britannia and waving a Union Jack. The poster reads "Gaitskell: $100 \%$ for Commonwealth." 261 On the right are Macmillan and Grimmond, dressed in French and

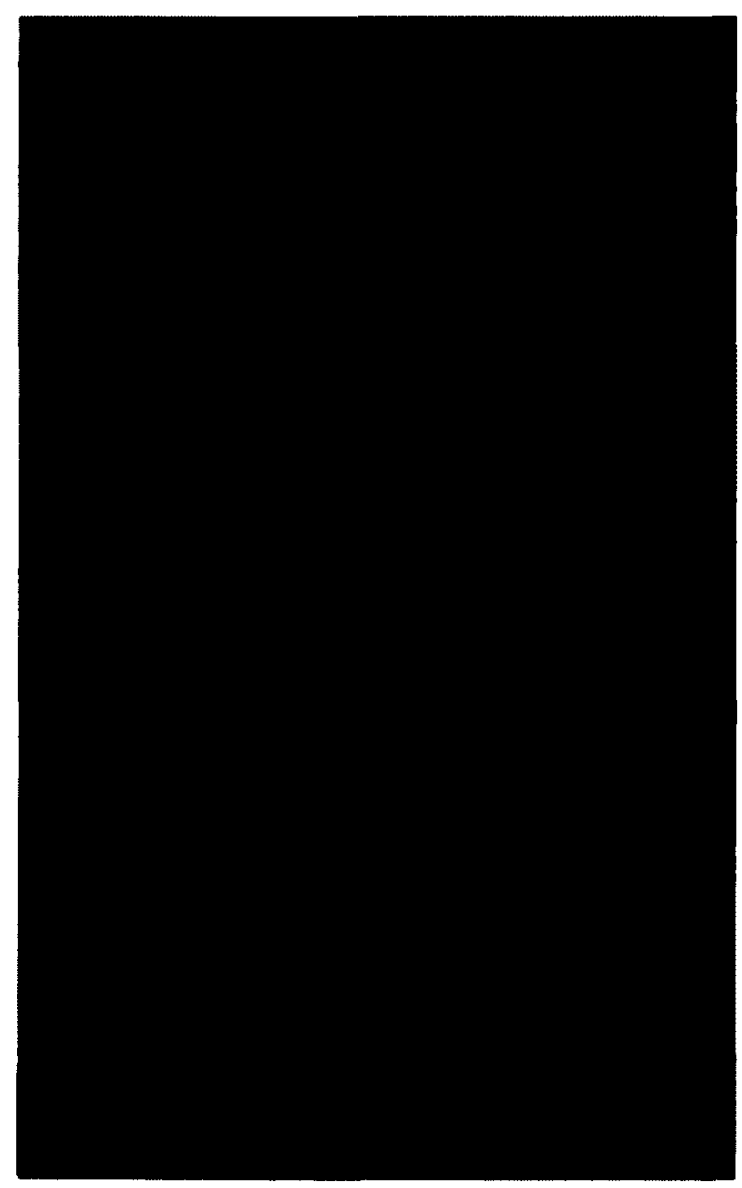

Figure 14 Daily Express, September 22, 1962

${ }^{259}$ Douglas Clark and Alexander Kenworthy, "But In the Background the Cry Grows - Let Voters Speak," Daily Express, September 21, 1962; "Challenge From Gaitskell," Daily Express, September 22, 1962.

260 "Challenge From Gaitskell," Daily Express, September 22, 1962.

261 The Liberal Party leader, Jo Grimond, was a vocal supporter of the Common Market. Throughout the Commonwealth Conference, he remained silent, and the press only mentioned him when the Liberal Party's annual meeting began at the end of September. 
in German clothing respectively. The poster reads "Macmillan and Grimond: $100 \%$ for Common Market" while the cartoon's caption exclaims: "Good heavens! After all these years to have to vote for the Socialists!" ${ }^{262}$ The gentleman, obviously an ex-officer, represents the glory of Britain's past. His identity and livelihood were tied up in the Empire, and he clearly believes in its continuing relevance. He is therefore willing to set aside his traditional political allegiance to the Conservative Party and to vote Labour in the next election, rather than risk endangering the Commonwealth.

The Daily Express did not believe that the British people would endorse a policy that threatened their heritage. On the front page of the September 22 issue, Gaitskell's words were boxed and printed in a large font. The newspaper drew particular attention to one quotation: "The Commonwealth is a tremendous force for peace because it embraces so many races and continents. I do not think the British people, given the chance to decide as they should be, will in a moment of folly throw away a tremendous heritage of history. ${ }^{263}$ Both the newspaper and the Labour leader were confident that public sympathy favoured the Commonwealth over the Common Market. There might be economic gains from European integration, but these could not justify the grave cultural and political losses that would occur if the Commonwealth was damaged. As a result, the newspaper wholeheartedly endorsed Gaitskell's call for an election before committing to such an important change in British policy and priorities. Even if the government could not be trusted to protect Britain's heritage, the "voice of the people" would not allow Macmillan to sacrifice the Commonwealth for economic gain. ${ }^{264}$

\footnotetext{
${ }^{262}$ Daily Express, September 22, 1962.

${ }^{263}$ Keith Renshaw, "An Election First," Daily Express, September 22, 1962.

264 “Challenge From Gaitskell," Daily Express, September 22, 1962.
} 
Most of the Guardian's coverage of Gaitskell's speech focused on his sympathy for the Commonwealth and its place in Britain's history and imagination. ${ }^{265}$ The newspaper reiterated that many of the Commonwealth fears were justified, that the current terms of membership were unsatisfactory, and the Conference had proven that Macmillan was unwilling to address Commonwealth concerns. In contrast, Gaitskell maintained his faith in the Commonwealth as a British community spread throughout the world. It represented the strength and character of the British nation, and had to be protected primarily for its importance to national identity. ${ }^{266}$

A political battle was brewing between Macmillan and Gaitskell over the Common Market. Macmillan was untrustworthy, but the Guardian feared that Gaitskell's use of the Commonwealth as a political weapon against the Prime Minister would backfire. Since the Commonwealth was made up of independent nations, it could not be controlled and restrained. As the Pappas' cartoon from September 22 showed, Gaitskell could lose control of the Commonwealth and end up headed in an unwelcome direction.

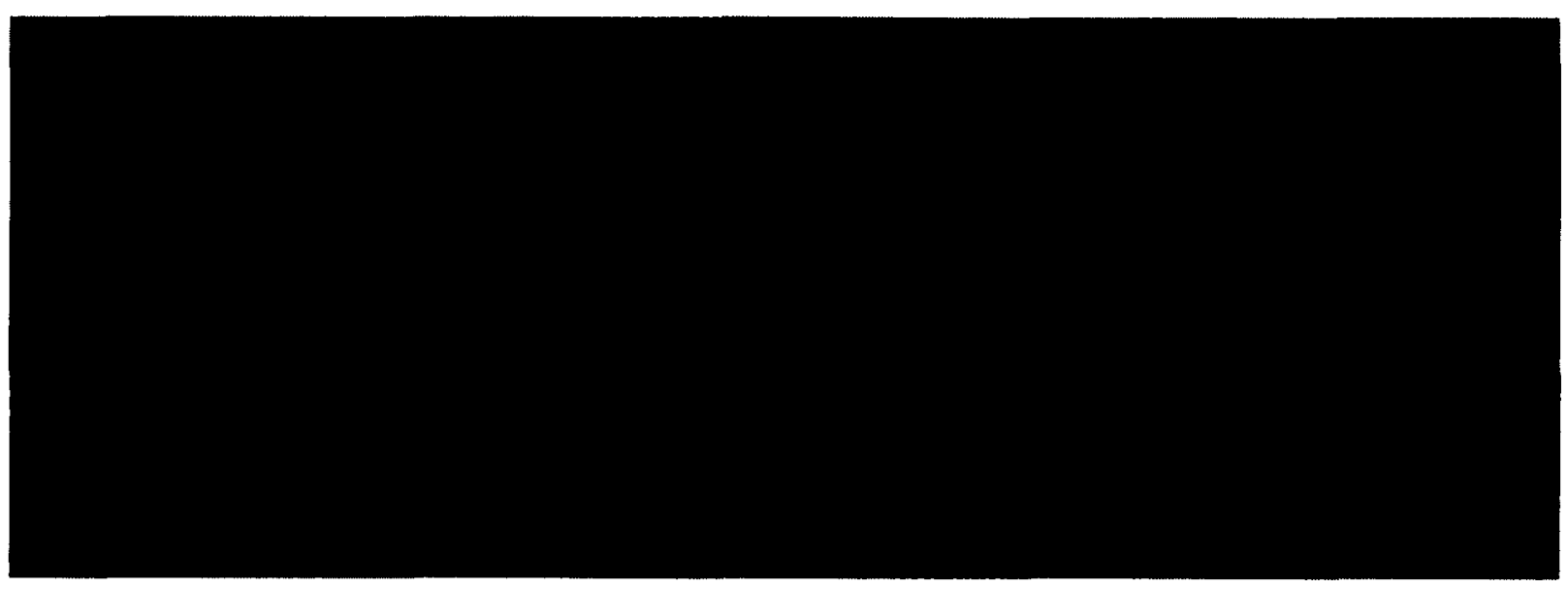

Figure 15 Guardian, September 22, 1962

265 "Putting 'Six' to the Electors," Guardian, September 22, 1962.

266 John Cole, "Mr. Cousins Softens the Tone on EEC," Guardian, September 22, 1962. 
While Gaitskell could, and should, advocate for the Commonwealth, he could not use it against Macmillan or hope to win a political battle with such a strategy. Otherwise, Gaitskell could end up with Macmillan in the political wilderness. Besides, according to the Guardian, the differences between the two major leaders were a matter of perspective. Macmillan was concerned with the long term benefits of the Common Market whereas Gaitskell worried about the details of membership. ${ }^{267}$ In order to ensure that Britain reached its full potential these two approaches would need to be joined. After all, neither politician was wrong; the difficulty lay in both leaders' tunnel vision and refusal to compromise.

The political implications of the Commonwealth Conference were a growing theme in the newspaper reports of late September. The leaders left London, but the debate and discussion over the role of the Commonwealth and the Common Market continued. In fact, as British political parties prepared for their annual conferences, leaders of all three parties were forced to contend with growing public confusion over the effects of European integration. After the end of the Conference, it was clear that many Britons maintained a deep emotional commitment to the Commonwealth. The political leaders would need to harness this belief in the continued importance of the Commonwealth in order to convince both their own party members and the general public to adopt their policies on the Common Market.

\footnotetext{
267 "The Battle in Britain," Guardian, September 22, 1962. The title itself is an invocation of the past and the Second World War.
} 


\section{Chapter: The Question of Direction - Commonwealth or Common}

\section{Market?}

Debate over changes to Britain's role in Europe and the Commonwealth featured prominently at the three political conferences that followed the Commonwealth Prime Ministers' meetings. Throughout September and October of 1962, public discourse over Europe and the Commonwealth grew, reflecting a preoccupation with the implications of Macmillan's European policy for the construction of "Britishness." Mounting concern was especially evident in the press and in the reflections of politicians on the foundations of British national identity. Throughout the period of the political conferences, these references became more explicit. In the press coverage of the Liberal Party conference, the issue of national identity was raised through the subtle use of national symbols, but by the end of the Conservative Party conference, newspapers and politicians were making explicit use of the phrase 'national identity' and deliberately drawing the links between certain symbols and Britishness. Over the course of two months, it became clear that concerns over membership in the EEC were directly tied to the reformulation of British national identity.

Debates that began during the Commonwealth Conference continued to feature prominently at these political conferences. ${ }^{268}$ Public discourse was very attentive to the question of Britain's future in the Commonwealth and in Europe, and the Liberal Party's

\footnotetext{
268 Although the Liberal leader, Jo Grimond, had been conspicuously absent from the press coverage during the Commonwealth meetings, the Liberal Party's conference began as the Commonwealth one ended. The press focused primarily on the politicians' reactions to Commonwealth anxiety about the EEC during the Conference. Grimond had long maintained that the Commonwealth would welcome British membership in Europe. The Commonwealth Conference seriously undermined his previous arguments, which may explain his rather conspicuous absence from both public debate and the newspapers. Jo Grimond. Speech to the House of Commons, 29 October, 1959 Parliamentary Debates, Commons, 5th ser., vol. 612 (1959), cols. 475.
} 
Conference was no exception. Liberal Party policy however, was unabashedly proEurope and debate over European policy during the Conference focused primarily on the Commonwealth and its future. Grimond did not perceive the Commonwealth as a family, holding instead that its purpose should be functional. ${ }^{269}$ The Liberal Party, in its promotion of European federalism, advocated a new vision of British identity, which assumed that Britain was a European state on par with the Six. Liberal support for the EEC was consistent throughout the 1950 s and 1960 s. $^{270}$ The Party was closely associated with support for the Common Market, having advocated the economic integration of Western Europe under British leadership. ${ }^{271}$ Not surprisingly, Macmillan's application for British membership in 1961 was greeted enthusiastically. For the first time the Liberal Party was joined by a major political ally in its appeal for institutional links between Britain and continental Europe. In fact, by 1962, members of the Liberal Party were calling for European federalism and political union, which neither of the other parties supported. ${ }^{272}$ For many Britons, European federalism would necessarily compromise British sovereignty in favour of supranational institutions and the loss of sovereignty threatened a keystone of national identity.

Undaunted, Grimond focused his Common Market address on the folly of the Conservative and Labour approaches to Europe. He claimed that only the Liberals

\footnotetext{
${ }^{269}$ Peter Barberis, Liberal Lion Jo Grimond: A Political Life (London: I.B. Taurus, 2008), 91.

${ }^{277)}$ Although there is evidence that the Liberal Party was originally divided between EFTA and EEC supporters, by 1959 Liberal policy was firmly pro-EEC. Richard S. Grayson, Liberals, International Relations, and Appeasement: The Liberal Party, 1919-1939 (London: Routledge, 2001), 155.

${ }^{271}$ Arthur I. Cyr, Liberal Politics in Britain $2^{\text {nd }}$ ed. (New Brunswick, New Jersey: Transaction Books, 1988), 81; Peter Barberis, Liberal Lion Jo Grimond: A Political Life (London: I.B. Taurus, 2008), 38.

${ }^{372}$ Michael Burgess, The British Tradition of Federalism (London: Leicester University Press, 1995), 160. In a letter to the editor Derick Abel, a delegate at the Liberal Conference, referred to "the emergent United States of Europe." Abel claimed that the eventual political union was anxiously awaited by many within the Liberal Party. Derick Abel, "The Approach to Europe," Guardian. October 4, 1962.
} 
offered a viable European policy. The Conservatives' application for membership in the EEC was a reluctant one, while the Labour Party leadership, in Grimond's words, "were the only generals in history who had ever galloped into battle sitting insecurely astride a fence." Moreover, they had now "fallen off the fence...on the wrong side."273 Grimond's indictment was popular with the Liberal Party delegates and both the Guardian and The Times compared the atmosphere surrounding his speech to a religious revival. ${ }^{274}$ According to these newspapers, the Liberals were firmly united in the belief that Britain's future prosperity was dependent on her redefining herself as a European rather than as an Atlantic and imperial power.

While much of the press advocated British membership in the EEC, few newspapers were willing to consider the Liberal Party`s Europeanist vision of national identity. Even the Guardian, which was one of the foremost supporters of the Liberal Party, foresaw difficulties in convincing the public to accept British participation in a federalist Europe. ${ }^{275}$ Indeed, those newspapers hoping to persuade the public that Britain should join the Common Market focused primarily on the economic ramifications of participation. ${ }^{276}$ Britons were less likely to object to European integration if they believed that it would only affect economic and employment prospects. ${ }^{277}$ If, however,

\footnotetext{
273 "The Change to Make a Dream Come True," Guardian, September 24, 1962.

274 "Delegates Disperse with Visions and Some Doubts," The Times, September 24, 1962; "Liberals' Glimpse of the Promised Land," Guardian. September 24, 1962.

275 "A Three Cornered Fight," Guardian, September 24, 1962.

${ }^{276}$ The Times is a prime example. The British application to join the EEC featured prominently in issues published during September 1962. Almost all of the articles focused on the economic impact of the Common Market.

277 Referred to as cost-benefit analysis, this type of argument is used to explain support for European integration. Scholars making use of this type of analysis argue that if Europeans perceive thenselves to be benefitting economically, support for integration remains high. Conversely. if economic benefits dip, support follows suit. Thus, support for integration should be highest in sectors benefitting the most from the European Union's policies. Matthew Gabel and Harvey D. Palmer, "Understanding Variation in Public Support for European Integration," European Journal of Political Research 27, no. 1
} 
Britons believed that membership in the EEC would lead to a loss of sovereignty to supranational institutions, they were likely to oppose entry since it would challenge the notion of Britain as an independent nation. ${ }^{278}$ Britons revelled in the notion of the Isles as an island fortress standing alone or with the Empire defiant against continental invasion threats from the Spanish Armada to the Battle of Britain. ${ }^{279}$

Knowing that a great many found the idea of European federalism abhorrent, Grimond's conference speech attempted to gloss over federalism, claiming that it might occur later in the integration process, but political union through existing institutions was the first goal. ${ }^{280}$ The Guardian believed that this strategy would backfire and wamed that instead of concealing its European policy, the Liberal Party had to openly discuss the political implications of EEC membership. ${ }^{281}$ If a European identity was to gain acceptance, the Party needed to take a leadership role in educating the public. Both the Daily Express and The Times agreed with the Guardian, believing that the Liberal Party

(1995): 3-15 and Matthew Gabel, "Public Support for European Integration: An Empirical Test of Five Theories" Journal of Politics 60, no. 2 (1998): 333-54.

${ }^{278}$ Recent work suggests that conceptions of identity play an often and perhaps neglected role in European integration. Several scholars claim that group membership and identity appear to be more powerful in explaining variations of public support than economic considerations. See Liesbet Hooghe and Gary Marks. "Does Identity or Economic Rational Drive Public Opinion on European Integration?" PS: Political Science and Politics 37, No. 3 (2004): 415-20; and Sean Carrey, "Undivided Loyalties: Is National Identity an Obstacle to European Integration?" European Union Politics 3, no. 4 (2002): 387-413. Both articles identify Britain's history as an imperial power and the traditional constructions of national identity as impediments to full participation in the European Union.

${ }^{279}$ For a powerful example of this idea see Winston Churchill's speech after the evacuation of Dunkirk: "Even though large tracts of Europe and many old and farnous States have fallen or may fall into the grip of the Gestapo and all the odious apparatus of Nazi rule, we shall not flag or fail. We shall go on to the end,...even if, which I do not for a moment believe, this Island or a large part of it were subjugated and starving, then our Empire beyond the seas, armed and guarded by the British Fleet, would carry on the struggle, until, in God's good time, the New World, with all its power and might, steps forth to the rescue and the liberation of the old." Winston Churchill, Speech to the House of Commons. June 4, 1940, Parliamentary Debates, Commons, 5th ser., vol. 36I (1940), col. 796.

280 "Liberal Assembly Concludes," The Times, September 24, 1962; Mark Bonham Carter, "Closer Unity in Europe," The Times, September 24, 1962.

281 "A Three Cornered Fight," Guardian, September 24, 1962. 
had gone too far and was likely to alienate its traditional supporters. ${ }^{282}$ In contrast, the Daily Mirror enthusiastically endorsed a new European basis for British national identity. According to that newspaper, the Liberal Party was the only political party that was not caught in the past and had taken the Labour Party's place as Britain's most progressive party. $^{283}$

Both the Liberal Party and the Daily Mirror faced the same difficulty of overcoming the continuing importance of the Empire and Commonwealth in the popular imagination. The Guardian believed that the Liberal Party had overlooked potential difficulties with European integration, particularly those related to the Commonwealth. ${ }^{284}$ The Party had made the mistake of assuming that Britons' emotional commitment to the Empire had faded with decolonisation and the establishment of the Commonwealth. This assumption, the Guardian warned, was faulty since even if the Commonwealth's economic value had faded, it continued to play an important emotional role in British society. $^{285}$

\footnotetext{
282 "What a Job to Find the Liberals!" Daily Express, September 22, 1962; "Off at a Gallop," The Times, September 22, 1962.

${ }^{283}$ John Beavan, "It's War on Two Fronts," Daily Mirror, September 20, 1962. Both the Daily Express, the Guardian and The Times echoed the Daily Mirror's claim that the Liberal Party had taken the Labour Party's role as Britain's radical leftist political party. Michael Cummings, Cartoon, Daily Express, September 25, 1962; "Off at a Gallop," The Times, September 22, 1962: "A Three Cornered Fight," Guardian, September 24, 1962.

${ }^{284}$ Francis Boyd, "Liberals Reaffirm Belief in Europe," Guardian, September 21, 1962.

285 Ibid. The Guardian claimed that the Liberal Party had to consider the needs of the Commonwealth. Britain needed to continue the European negotiations, not only because of her Commonwealth conmitments, but also to be able to judge whether the EEC would allow Britain to exert a leadership role. If the British could convince the Europeans to concede to better terms, there would be evidence that Britain would be able to play an influential role in further European development. If, however, the Six were unwilling to compromise. Britain would be given a clear indication that it was intended to take on the role of subordinate partner. Under no circumstances could Britain consider a policy that would leave it subservient to France or Germany. British power might have faded during the twentieth century, but Britain could not accept a second class position in Europe. "Our Voice in Europe," Guardian, September 21, 1962.
} 
Other newspapers shared the Guardian's belief that the Liberal Party was ignoring the continuing relevance of the Commonwealth. Predictably the Daily Express was the most vitriolic. ${ }^{286}$ As far as the paper was concerned, Liberal Party policy would destroy the British Empire, the Commonwealth and Britain. While The Times did not concur with the Daily Express's conclusions, it did share the belief that Grimond and the Liberal Party had erred greatly in attacking the Commonwealth. ${ }^{287}$ The Liberal Party needed to finesse its proposal for European integration to ensure the well being of the Commonwealth, if it wished British membership in the EEC to gain widespread acceptance.

The press agreed, however, that the Liberals suffered from tunnel vision. In focusing exclusively on the benefits of membership in the EEC, they had lost sight of popular constructions of national identity. This failure to consider the influence of tradition caused the Party to lose touch with the general public. It had become an academic, rather than a popular party, and its vision for Britain did not resonate sufficiently with the general public to challenge traditional constructions of national identity.

The two other parties were attracted by many of the same arguments. Several of these were employed by George Brown, when as deputy leader he addressed the Labour Party. He noted the opportunity which integration presented Britain to lead Europe into the future, to shape its development and social conscience as well as to benefit

${ }^{286}$ See Michael Cummings's cartoon in Daily Express, September 21, 1962.

287 "Commonwealth Should Lead the World," The Times, September 24, 1962. The Times also claimed that the Liberal Party was charging "bald headed for European federalism" and that party did not seem to realise how deeply European federalism would affect the British population In fact, according to The Times, the Liberal Party seened almost flippant in its European platform. "Off at a Gallop"; "Liberals Commit Themselves To European Federalism," The Times, September 21, 1962. 
economically from the Common Market. ${ }^{288}$ Nevertheless, the debate over the Common Market was a divisive force in both the Labour Party and the Conservative Party. Some members viewed European integration as an opportunity, while others saw it as a threat. European integration certainly offered economic benefits for Britain, but membership in the EEC posed ideological difficulties. Much of the discomfort with European integration originated with assumptions about the nature of Britishness, most of which revolved around Britain's relationship with the Commonwealth. ${ }^{289}$ For two hundred years Britain's priorities had focused on its overseas colonies and trade routes rather than on Europe.

The Labour Party's leader, Hugh Gaitskell, had refused to commit to a clear position on British membership in the EEC preferring to keep his party officially neutral. ${ }^{290}$ This position allowed him to maintain a semblance of unity within the party. Publicly, Gaitskell was able to oppose the terms of the application without actually opposing membership in the EEC. ${ }^{291}$ Privately, however, Gaitskell was less ambivalent: his uncertainty about British participation in the Common Market had been transformed into opposition by September 1962. This change was driven not only by his belief that the French would block British entry, but also by his deep emotional commitment to the Commonwealth and faith in its potential to affect international relations. Gaitskell was

\footnotetext{
${ }^{288}$ George Brown, "In a Speech to the 1962 Annual Conference of the Labour Party" Address to the Annual Labour Party Conference. October 3, 1962 in Britain and the Common Market (London: Labour, 1962), 25.

${ }^{289}$ Anthony Foster, Euroscepticism in Contemporary British Politics: Opposition to Europe in the British Conservative and Labour Parties since 1945 (London: Routledge, 2002), 16.

$\left.{ }^{29}\right)$ Gaitskell was attempting to avoid another split in the Labour Party after the debate over defence the year before. Brian Bivati, Hugh Gaitskell (London: Richard Cohen Books, 1996), 405.

291 Bivati, 406.
} 
convinced that Britain had an important role to play on the world stage. ${ }^{292}$ While he was not opposed in principle to the idea of European integration, he did not believe that Britain's future prosperity would be best served by the Common Market. Many Labour MPs, trade unions and constituency organisations shared Gaitskell's conviction, and Labour policies throughout the post-war period stressed the importance of maintaining British sovereignty and historical traditions. In fact, it was Labour's devotion to the Commonwealth that was its leading argument against joining the Common Market.

The Labour Party remained convinced that the Commonwealth, which had been engineered by Clement Atlee's government, was central to maintaining British international prestige and sustaining the capacity to influence world events. ${ }^{293}$ Gaitskell, who had succeeded Attlee as leader in 1955 and many other members of the Labour Party feared that membership in the EEC would destroy the economic links between Britain and the Commonwealth, and adversely affect other aspects of the relationship. ${ }^{294}$ Throughout the 1950s, Labour MPs had been vocal critics of the government's European policy, believing that continental links were being fostered at the expense of the Commonwealth. ${ }^{295}$ Labour had been committed to the creation of the Commonwealth as a progressive multiracial organisation of equal partners and the Party wished to encourage this development rather than accept a policy that threatened its survival. For

\footnotetext{
${ }^{292}$ Bivati, 413.
}

${ }^{293}$ Clemens A. Wurm, "Great Britain: Political Parties and Pressure Groups in the Discussion on European Union" in Documents on the History of European Integration Volume Three: The Struggle for European Union by Political Parties and Pressure Groups in Western European Countries, 1945-1950, eds. Walter Lipgens and Wilfried Loth (European University Institute: New York, 1988), 633.

${ }^{294}$ Brivati, 413.

${ }^{295}$ Anthony Forster, Eurosceptism in Contemporary British Politics: Opposition to Europe in the British Conservative and Labour Parties since 1945 (London: Routledge, 2002), 18. 
many members of the Labour Party, therefore, the Commonwealth remained the primary means whereby Britain could hope to exert itself on the world stage.

The Labour Party Conference responded directly to many of the questions raised at the Commonwealth Prime Ministers' Meetings. Discussions of the Commonwealth and the Common Market dominated both the Conference as well as its coverage in the newspapers. In a statement published immediately before the Conference opened on October 1, 1962, the Labour Party National Executive expressed its reservations regarding British membership in the EEC. This statement was the first clear indication of Labour's European policy and it unequivocally condemned the terms of entry negotiated by the Macmillan government. While the document focused on the unfavourable economic impact of the Common Market on the Commonwealth, it also articulated Labour's ideological dilemma over Europe. The Labour Party acknowledged that Britain had a role to play in Europe, but it could not accept the idea that Britons were solely Europeans since " $[\mathrm{u}]$ nlike the Six, Britain is the centre and founder member of a much larger and still more important group, the Commonwealth."296 The document emphasised that under no circumstances could Britain abandon its commitments to the Commonwealth: "our situation is not the same as that of the other countries of the Community. While our histories have certainly overlapped, they have also diverged, and this has shaped our separate institutions and policies. Our connections and interests, both political and economic, lie as much outside Europe as within it."297

\footnotetext{
296 "Labour and the Common Market: Statement by the National Executive Conmittee $29^{\text {th }}$ September, 1962," in Britain and the Common Market (London: Labour Party, 1962), 33.

297 Ibid.
} 
The National Executive Committee challenged the editorial position of proMarket newspapers that were also sympathetic to the Labour Party such as the Guardian. This paper hoped that Labour's foot dragging with respect to the Common Market was not caused by a true ideological opposition to British participation, but stemmed from pragmatic political concerns, since the Labour Party could not be seen to support a Conservative initiative without exposing itself to potential electoral damage. ${ }^{298}$ The Daily Mirror also expressed its faith in Labour's underlying pro-Common Market leanings, while the Daily Herald chose to emphasise the unacceptability of the terms of membership rather than the principle of the EEC as, Gaitskell's growing hostility clearly unnerved the leftist newspapers. ${ }^{299}$

According to The Times, this change in policy could be linked directly to the Commonwealth Prime Ministers' meetings. ${ }^{300}$ The newspaper implied that the Commonwealth's hostility towards the EEC led Labour to believe that the Conservative government had lost touch with the public. To test opinion, the Labour Party expressed a readiness to go to the country, arguing that the Commonwealth was central to British power and prestige. ${ }^{301}$ Quickly countering the unwelcome Labour manoeuvre, The Times claimed that a question of such fundamental centrality to Britain's future should not be

${ }^{298}$ Francis Boyd, "Labour's Self-Portrait," Guardian. October 2, 1962.

299 John Beavan, "Set Fair for Gaitskell," Daily Mirror, October 1, 1962; "Only Labour Can End the Tory Shambles," Daily Mirror, October 1, 1962; "Hugh Gaitskell Says: We Must Bargain, but We Must Not Crawl." Daily Herald, October 1, 1962.

300 "Labour in Conference Today: Some Doubt on Final Market Policy," The Times, October 1, 1962. While there were links between the Labour Party and the TUC, they were separate organisations and did not always agree on policy. The Times article went on to claim that a long overdue break between Labour and the unions might occur over British participation in the Common Market.

${ }^{301}$ The last general election had been held three years before in October 1959 and had returned a large Conservative majority. The Conservatives held 365 seats, Labour held 258 and the Liberals held 6 seats. While an election was not imminent, Labour's call for an election in the near future was not unreasonable. Colin Rallings and Michael Thrasher, British Electoral Facts, 1832-2006 (Aldershot: Ashgate, 2007), 59. 
decided by an election. In the British Parliamentary system, The Times noted "although power [came] ultimately from the people, authority to govern... [did] not rest with the people. It rest[ed] with the Government, which depend[ed] for the exercise of its authority on the maintenance of a Parliamentary majority."302 The newspaper claimed that instead of defending British traditions, the Labour Party was exploiting a public misconception that the people were the final political authority. The Daily Express however disagreed fundamentally. While it was a fierce opponent of socialism, the Daily Express welcomed Labour's statement. ${ }^{303}$ Indeed, the Daily Express interpreted recent Labour by-election victories as evidence that the public was abandoning the Conservative Party because the Tories had abandoned the Commonwealth. ${ }^{304}$ According to this newspaper, Conservative policies were increasingly out of touch with a public that still believed in the centrality of the Commonwealth. Labour was emerging as its new defender. ${ }^{305}$

William Barkley, the Daily Express's Parliamentary correspondent, published an open letter to the Labour Party after the publication of its statement on the Common Market. $^{306}$ Addressing members of the Labour Party as "Dear, Dear Comrades," he expressed surprise at finding that he shared a devotion to the Empire with socialists. He emphasised the common ground between the Daily Express and the Labour Party over the importance of the Commonwealth. Claiming that the Commonwealth was the "only hope of peace" in a world torn apart by the Cold War, he reminded readers that Europe

\footnotetext{
302 "Market Election?" The Times, October 1, 1962.

303 "The People Look to Gaitskell," Daily Express, October 1, 1962.

${ }^{304}$ Ibid.

${ }^{305}$ See the editorial cartoon in Daily Express, September 21, 1962.

${ }^{306}$ William Barkley, "Dear, Dear Comrades," Daily Express, October 1, 1962.
} 
had been the source of war rather than peace during the first half of the twentieth century. ${ }^{307}$ Britain had always looked outward to the Empire and Commonwealth, a proven source of power and prestige. Barkley questioned how the head of a world-wide community could seek economic salvation across the English Channel. ${ }^{308}$ A betrayal of the Commonwealth amounted to a betrayal of Britain and its interests. Sticking with the Commonwealth, Barkley argued, offered the best hope for Britain to regain its political independence and economic strength.

Hugh Gaitskell adopted very similar language in his address to the delegates on October $3,1962 . .^{309}$ His choice of words and imagery was calculated to make an emotional impact on the delegates and to awaken their sense of national pride. Gaitskell claimed that membership in a federated Europe would mean the end of British independence and "a thousand years of history.", B10 using nationalistic imagery, Gaitskell hoped to unite the Labour Party through a powerful invocation of British identity. Gaitskell emphasized that Britain would cease to be a nation and questioned how Britain, as a subsidiary of Europe, could hope to retain its position "as the 'mother country' to a series of independent nations." ${ }^{311}$ Using the same familial language so frequently employed during the meetings of the Commonwealth Conference, he argued that Britain could not abandon her children in order to pursue her own interests. Such a course would be a betrayal of British tradition. Gaitskell related how horrified he had been at the "bitterness and hostility" that had developed between the British and other

${ }^{307}$ Ibid.

${ }^{308}$ Ibid.

${ }^{309}$ This speech drew heavily on his speech to the nation in on September 21

${ }^{310}$ Hugh Gaitskell, "In a Speech to the 1962 Annual Conference of the Labour Party," in Britain and the Common Market (London: Labour, 1962), 12.

"III Ibid. 
Commonwealth Prime Ministers over the Common Market. ${ }^{312}$ The Labour Party, he stated, was committed to ensuring that there was no further damage done to these important historic relations and he reminded the members that the first post-war Labour government had presided over the establishment of the Commonwealth. No course of action that threatened its survival would be acceptable. Gaitskell reminded delegates that the Commonwealth had answered Britain's greatest need by sending soldiers to fight in two world wars. Canadians, Australians and New Zealanders had died alongside their British brothers and the Dominions had offered other assistance through loans and low food prices, both during and after the Second World War. ${ }^{313}$ The Commonwealth had demonstrated its loyalty to the mother country multiple times in the fight against tyranny. The Conservative government, Gaitskell contended, had asked Britons to forget their heritage, their identity and their moral obligations. Labour, however, would not do so: "we, at least, do not intend to forget Vimy Ridge and Gallipoli; we, at least, do not intend to forget the help they gave us after this last war." 314

Gaitskell repeated the National Executive's claim that Britain and Europe were not the same. Pointedly, he stated that British history deviated sharply from European history; whereas the British Empire had evolved into the Commonwealth, the European empires had ended in bloodshed: "there is another side in Europe and in the European Movement $-\ldots$ the story of the Congo and Algeria...."315 He questioned whether Britons truly wished to be European "for although, of course, Europe has had a great and glorious civilisation...there have been evil features in European history, too - Hitler and

${ }^{312}$ Gaitskell, "In a Speech to the 1962 Annual Conference of the Labour Party," 19.

${ }^{313}$ Ibid.

314 Ibid., 16.

${ }^{315}$ Ibid., 22. 
Mussolini and today the attitude of some Europeans to the Congo problem, the attitude of at least one European government to the United Nations." ${ }^{316}$ These tendencies ran contrary to British traditions and values, and could lead to conflict. According to Gaitskell, such a serious decision as that contemplated by the Macmillan government demanded public consultation. The Labour Party would have to defend the right of the British people to shape the future of their nation. ${ }^{317}$ Accordingly, he repeated his demands that an election be called before the Government committed Britain to membership in the EEC, since joining the Common Market would mark an abrupt change in the course of British history.

Press response to Gaitskell's speech varied greatly. Many applauded his commitment to the Commonwealth. The Daily Herald, for example, agreed that the Commonwealth contributions to Britain's defence, particularly in the Second World War, should be remembered. ${ }^{318}$ The Commonwealth had proven its loyalty and had helped to ensure the survival of the motherland; Britain now had a responsibility to see that the Commonwealth thrived in the new Europe. The Pro-Market press, however, was concerned that Gaitskell would polarise Labour into opposing camps, and the Daily Herald claimed that Gaitskell was using nationalistic language in order to popularise his position on the Common Market. The newspaper related, with relief that the conference had ended on October 5 with "no rancour about nationalism.",319

Gaitskell's fiery language left some newspapers convinced that Labour was fundamentally opposed to the Common Market, even though he claimed repeatedly that

\footnotetext{
${ }^{316}$ Ibid.. 10.

${ }^{317}$ lbid., 21.

318 "A Day of Triumph for Mr. Gaitskell," Daily Herald, October 4, 1962.

319 "The World This Morning," Daily Herald, October 6, 1962.
} 
he was opposed to the terms, not the idea, of British membership in the EEC. ${ }^{320}$ Several newspapers concluded therefore, that Labour's position made membership impossible because the EEC would be unlikely to accommodate the maintenance of Commonwealth relations as Britain's top priority. Newspapers that preferred to ignore the nationalistic elements of the debate over the Common Market, such as The Times, found reporting on Gaitskell's speech problematic and chose to gloss over it. The newspaper published the speech, but refrained from comment. In contrast, the Daily Express, which had a long history of using nationalistic rhetoric in the fight against British membership in the EEC, devoted its first, second and editorial pages to the coverage of the Labour debate over the Common Market. According to this paper, Gaitskell signalled his opposition to European integration by outlining his continued adherence to the theory that only Britain stood at the intersection of three concentric circles: the Atlantic world, the Commonwealth and Europe. $^{321}$ Britain was not simply another European country; it had always been distinct, and tradition meant that Britain had political, economic and emotional attachments and commitments throughout the world, as well as a national identity, which embraced a global perspective.

Newspapers sympathetic to both the Labour Party and the Common Market, such the Daily Mirror and Daily Herald, were naturally forced to reconsider their political loyalties. The Daily Mirror, while still ideologically sympathetic to the Labour Party, was determined to oppose its Market stance, claiming that not all members of the

${ }^{320}$ The Guardian, in contrast to The Times, had interpreted the National Executive Statement as ambivalent towards British membership in the EEC. After Gaitskell's speech, however, the newspaper claimed that Labour appeared to be completely opposed to the Common Market. "One Cheer for Europe," Guardian, October 4, 1962.

${ }^{321}$ Gaitskell, "In a Speech to the 1962 Annual Conference of the Labour Party," 23. 
Party backed Gaitskell. The newspaper tried to refute the view of a Labour Party united against British membership in the EEC by explaining that many Labour delegates were "conducting a silent campaign to support entry into the Common Market" by wearing badges with bearing the word 'Yes.",22 According to the newspaper, the 'Yes' men appeared to outnumber the 'No' men.

Unlike the Daily Mirror, the Daily Herald portrayed the conference delegates as united behind Gaitskell. He had given "the most triumphant speech of his career..."and it reported that: "he carried the entire Labour Party Conference with him." 323 The conference had ended "united and in a victorious mood." 324 Significantly however, the newspaper did not herald consideration of the opportunities presented by the EEC as well as the challenges. ${ }^{325}$ The Daily Herald supported the Labour Party's call for further negotiations with the Common Market, but insisted that British membership should be a priority.

In contrast to the leftist newspapers, the normally anti-socialist Daily Express threw its support behind Gaitskell's position on the Common Market, believing that it finally had an ally. The day after Gaitskell's speech, the Daily Express featured a Cummings cartoon of Gaitskell dressed as Britannia and Macmillan dressed in stereotypical French costume: a beret and black suit. Gaitskell stood guard over Britain while Macmillan fled on to a ship, leaving a suitcase labelled "one thousand years of

\footnotetext{
322 "'Yes' and 'No' Men in a Silent Clash on Market," Daily Mirror, October 1, 1962; "The Man Who Must Think Again: The Mirtor's Verdict on the Gaitskell Speech," Daily Mirror, October 12, 1962.

323 "A Day of Triumph for Mr. Gaitskell," Daily Herald, October 4, 1962.

324 "The World This Morning," Daily Herald, October 6, 1962.

325 "Labour and the Market," Daily Herald, October 4, 1962.
} 
history" behind. ${ }^{326}$ Macmillan was abandoning the legacy of history because he knew that it would interfere with membership in the EEC. In striking contrast, Gaitskell was draped in the symbols of British identity and power.

Figure 16 Daily Express, October 4, 1962

The Commonwealth was essentially a continuation of the imperial project, the cornerstone of British identity according to the Daily Express and it applauded what it perceived as Labour's new commitment to maintain the Empire: "Hugh Gaitskell has spoken for the people. He has voiced the country's loyalty for the Commonwealth." 327 Labour's newly minted adherence to traditional Tory symbols, however, caused much understandable consternation and bemusement among its rank and file.

The Daily Express applauded Gaitskell because he had spoken for the people, voicing their loyalty to the Commonwealth through his speech. ${ }^{328}$ Where Macmillan had lost the confidence of the nation, Gaitskell had read its heart. Unlike Macmillan, Gaitskell realized that the debate over the Common Market was much more than a debate

326 "Gaitskell Day," Daily Express, October 4, 1962. One example was the Royal Navy which was seen as "still [ruling] the seas - glorious and glamorous." "Still Glorious." Daily Express, October 4, 1962. 327 "The Verdict," Daily Express, October 4, 1962.

328 Ibid. 
about economics, it was about national identity. Appeals for Britain to remain true to its history and traditions rather than giving up sovereignty and becoming subjugated to Europe were used by the Daily Express. The paper was convinced that economic integration was one step towards a federated Europe, which would destroy British independence and identity. ${ }^{329}$

A Cummings cartoon in the Sunday Express of October 7, 1962 brilliantly demonstrated the confusion of views. It showed the Labour and Conservative Party conferences side by side. Labour leaders Frank Cousins, Hugh Gaitskell and Harold Wilson are shown on a platform decorated with a Union Jack, singing "Land of Hope and Glory" under a banner that proclaims "For Queen \& Empire!" while the Conservative Party leaders Harold Macmillan, Edward Heath and Iain Macleod are shown on a similar platform, but one decorated with a large ' 6 ', symbolizing the six members of the EEC. The three men are singing "The Marseillaise" under a banner that proclaims "For Brussels \& Federation!" A confused man stands at the bottom of both images wonders if he has mistakenly stumbled into the wrong building, since the politicians are defying their traditional identities and party rhetoric. Noteworthy is Cummings's portrayal of the Labour delegates singing in ordered harmony, where the Conservative delegates are a hodgepodge of characters, several of whom are directing knives at Macmillan's back. The Daily Express believed that the grassroots of the Conservative Party felt that Macmillan had deceived them by abandoning those elements, like monarchy and Empire, which identified and defined traditional Conservative values. Many hoped that Labour's

${ }^{329} \mathrm{Ibid}$. 
stand would encourage Conservative politicians to revolt and to speak out against the

Common Market. ${ }^{330}$

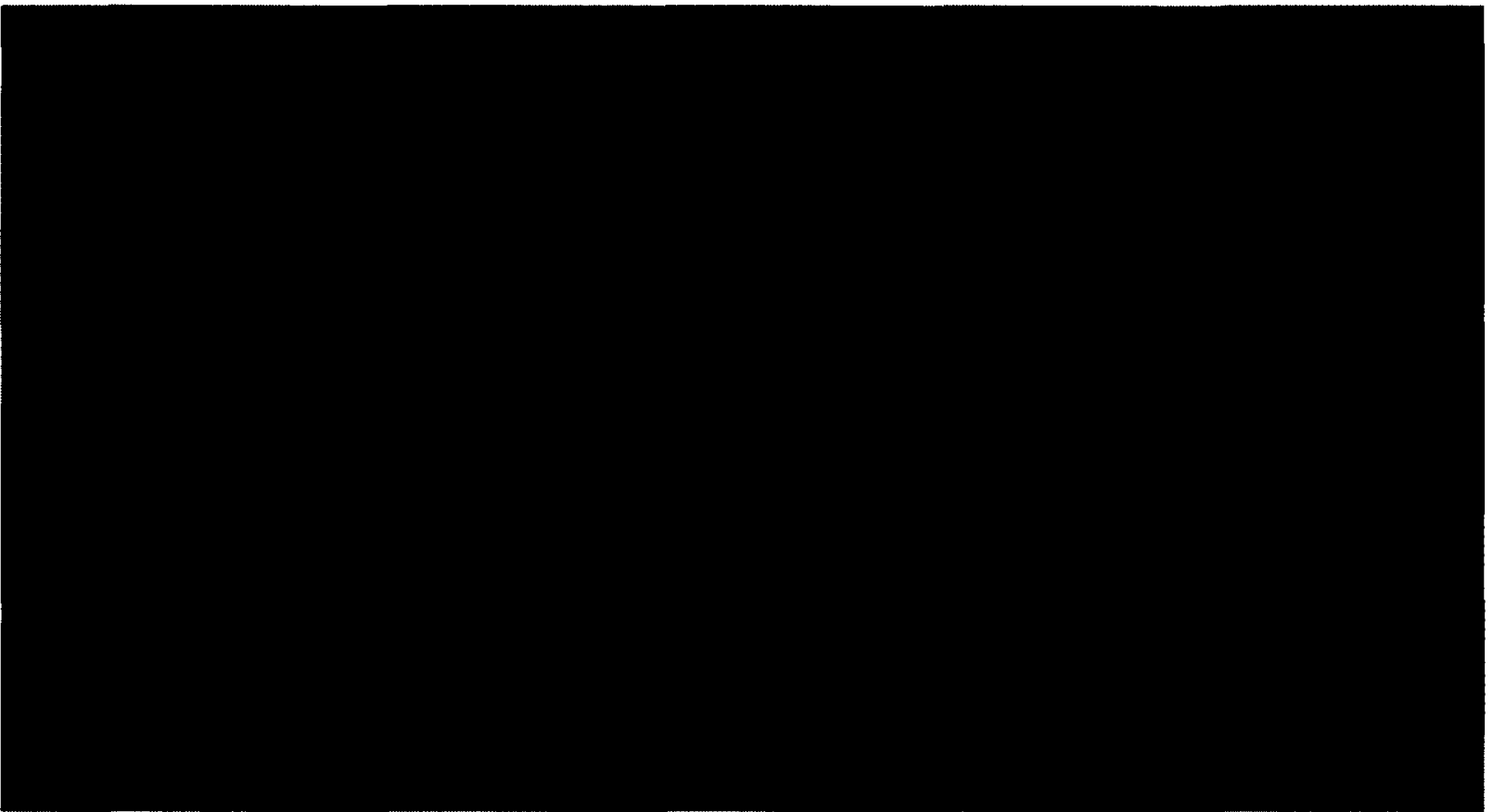

Figure 17 Sunday Express, October 7, 1962

During the debate over the Commonwealth, the Daily Express portrayed the instruments of Empire as retaining relevance. Some of them might have changed, but the emotional and nationalistic ties remained, especially between the mother country and the "settler colonies." formed a common language that the public would immediately understand. The Daily

${ }^{330}$ The Daily Express's readers expressed two main reservations about the Labour Party. First, they questioned how deep Labour's commitment to the Commonwealth really was, asking if the party would sing "Land of Hope and Glory" or "Rule, Britannia" rather than "Red Flag" at their next meeting. "Dear Sir: From You to the Express," Daily Express, October 1, 1962. Secondly, they pointed out that Labour had caused inordinate domestic damage during its tenure and suggested that a new party was needed to "foster the expansion of the Commonwealth and work to develop it as the greatest force in the world." "Letter of the Day," Daily Express, October 5, 1962.

331 Also referred to as the 'White Dominions', Canada, Australia and New Zealand had been granted full independence, but since the majority of their populations were of British descent, the emotional connections with Britain remained strong. Stuart Ward, Australia and the British Embrace: The Demise of the Imperial Ideal (Melbourne University Press: Melbourne, 2001), 10. 
Express's references to the glorious history of the Royal Navy reminded Britons that they had inherited a proud tradition of naval strength, characterised by outward expansion. Britain was still tied to the sea, its ships "ageing ...but they still rule., ${ }^{332}$ The newspaper's emphasis on Britain's successful transition from Empire to Commonwealth reinforced the positive results of British imperial policy. Trinidad was "launched as a nation with a healthy economy, political stability and racial harmony. Fruits of the 'colonial rule' that some people love to deride!"”333 The colonies of Britain, unlike those of the continental Europeans became, for the most part, peaceful and stable countries that maintained their relationship with the mother country. Gaitskell's references to Commonwealth soldiers fighting together in the First World War reminded listeners that this family had banded together to fight against tyranny and dictatorship. Now the Commonwealth, a multiracial family of nations, offered the best hope for peace in a world divided by the cold war. ${ }^{334}$ Furthermore, Britons had battled together to force parliamentary reform during the nineteenth century in order to ensure that liberty was victorious. Britons would not stand by and allow "reactionary nonsense [to be] thrust upon [them] again. ${ }^{335}$ These were all components of Britishness that needed to be safeguarded for future generations. The implication was clear: Britain could not afford to participate in an endeavour that would threaten its national identity.

The Daily Mirror believed that Gaitskell's brand of British nationalism was out of date. The newspaper accused the Labour Party of embracing nationalism at a time when the rest of European socialism was abandoning it for something new and better in the

\footnotetext{
332 "Still Glorious." Daily Express, October 4, 1962.

333 "The Heirs," Daily Express. September I, 1962.

${ }^{334}$ Gaitskell, "In a Speech to the 1962 Annual Conference of the Labour Party," 16.

${ }^{335}$ Ibid., 22.
} 
form of supranational institutions. ${ }^{336}$ Furthermore, Gaitskell was accused of embracing a narrow and parochial type of nationalism, and criticized as a coward for constantly looking to history. The Conservatives, on the other hand, were being courageous enough to look to the future, even if it meant forging a path away from British traditions. ${ }^{337}$ The newspaper believed that fear of the future was chronic amongst Britons, and explained that this was causing them to fall behind the rest of the world. ${ }^{338}$ Since most of the British were living in the past, the Daily Mirror recognised that Gaitskell's skilful choice of words and images would give his speech great emotional appeal. In consequence, the newspaper feared that the fate of Britain, and its place in the new Europe, would be adversely affected. ${ }^{399}$ The Daily Mirror contended, however, that Britain could not sacrifice its power and prestige for a romantic idealisation of the past. Instead, the British had to embrace the way of the future, which lay in Europe.

Both the Guardian and The Times also accused Gaitskell and the Labour Party of focusing on the past rather than the future. The Guardian explained that the era of narrow nation-states was drawing to a close and a new age of internationalism was beginning. Britain could not thrive by embracing policies that isolated the country from the rest of Europe. ${ }^{340}$ The Times agreed, painting the debate as a generational one. The young and modern minded wanted to see Britain embrace the new trends of economic and political integration. ${ }^{341}$ Questioning Labour's motives, the newspaper claimed that although Gaitskell's views might appeal to more conservative Britons, he would quickly

\footnotetext{
336 "The Man Who Must Think Again: The Mirror's Verdict on the Gaitskell Speech," Daily Mirror, October 12, 1962.

${ }^{337}$ Ibid.

${ }^{338}$ Cassandra, "l Hear the Tramp of History Pass Us By," Daily Mirror. October 4, 1962.

334 "Why the Mirror is Publishing Gaitskell's Speech IN FULL," Daily Mirror, October 6, 1962.

340 "One Cheer for Europe," Guardian, October 4, 1962.

341 "Hardening Against the Market," The Times, October 4, 1962.
} 
lose support amongst the young and such a strategy would be disastrous for a party hoping to govern. Labour could not lose touch with youth, since to do so would be to mortgage its future.

Regardless of whether or not they endorsed Labour's position on the Common Market, all of the newspapers agreed that Gaitskell's speech had made a significant contribution to the debate over British membership in the EEC. His references to the importance of the Commonwealth and his claim that membership in the EEC would put an end to autonomy acknowledged public fears that Britain would be subsumed into a European federal state. Gaitskell also gave credence to the Daily Express's claims that the debate over British participation in the Common Market was a question of identity, not of economic policy. References to glorious episodes in British history, such as imperial brothers fighting side by side to defend the mother country, and an emphasis on the differences between Britain and continental Europe, such as Britain's continued relations with its independent colonies, reflected popular constructions of national identity. Even The Times agreed that there were fundamental differences between Britain and continental Europe not withstanding their overlapping history. ${ }^{342}$

The Conservative Party published its conference agenda on September 26, just a few days after the Liberal Party and the Commonwealth Prime Ministers had concluded their meetings. The British newspapers expressed surprise at how little time the Conservatives had scheduled to debate the issue of the Common Market, preferring to focus on domestic concerns for the greater part of the conference. ${ }^{343}$ The newspapers

\footnotetext{
${ }^{342}$ Ibid.

${ }^{343}$ See "The Tories Plan Their Conference Time-Table," Daily Express, September 26, 1962; Francis Boyd, "Elegy for Orpington," Guardian, September 26, 1962; "Debates On Six At Llandudno And
} 
were convinced that party loyalty would win out over personal beliefs and that Macmillan's policy would be approved by the delegates.

The Daily Mirror claimed that the government expected seven to one support for British membership in the EEC. ${ }^{344}$ While the Guardian also agreed that the government's policy should be approved by a large margin, The Times, however, was not convinced that Macmillan's time at the Conference would be an easy one. ${ }^{345}$ The newspaper pointed out that the debate allotted equal time for those who supported and those who rejected the Common Market. More importantly, the motions to be discussed at the Conference had to be submitted at the beginning of September and 27 of the 31 submitted by that time were favourable to the Common Market. The Times believed that, in the intervening month, the results of the Commonwealth Conference had altered public opinion. $^{346}$

The Conservative leadership did indeed fear that the question of the Commonwealth and Common Market could potentially split the party. Indicative of the intensity of feeling was the fact that Churchill's son-in-law, Duncan Sandys had pledged to leave public life rather than to help destroy the Commonwealth. ${ }^{347}$ In an attempt to consolidate his position, Macmillan published a pamphlet to be distributed to conference delegates explaining the rationale for entry. The pamphlet also addressed the challenges presented by opponents to the British application for membership, notably those raised by

Westminster," The Times, September 26. 1962. The Guardian claimed that the conference program showed a change in priority for the Conservative Party: the Commonwealth was no longer of primary concern. "The Conservative Conference," Guardian, September 26, 1962.

.44 William Greig, "YYes" to Europe: Macmillan Expects a Thumping Tory Majority for the Market," Daily Mirror, September 26, 1962.

3.5. "The Conservative Conference," Guardian. September 26, 1962; "Debates On Six Al Llandudno And Westminster," The Times, September 26, 1962.

346 "Debates On Six At Llandudno And Westminster," Guardian, September 26, 1962.

347 "Sandys Gives a New Market Pledge," Daily Express, September 27, 1962. 
Gaitskell in his speech to the Labour Party. Furthermore, for the first time, Macmillan directly addressed concerns over British national identity.

The Prime Minister acknowledged that the application for membership in the EEC had created anxiety for many Britons. Macmillan blamed these concerns on fear mongers, who claimed that Britons would "lose all [their] national identity by joining the European Community." ${ }^{348}$ Countering Gaitskell's argument that Britain would become a 'province' of Europe, Macmillan stated that critics had exaggerated the effects of membership on British sovereignty and identity. "The British public and Conservative government," he wrote, "were firmly against the extinction of separate national identities, and would choose a Europe which preserved and harmonised all that is best in our different national traditions." ${ }^{349}$ Macmillan insisted that rather than destroy British national identity, membership in the EEC was intended to protect, expand and enhance Britain's international prestige. The Conservative policy did represent a break with Britain's traditional relationship with continental Europe, but Britain needed a modern and forward looking policy in order to succeed in the contemporary world.

Integral to the debate over national identity were concerns about sovereignty. Macmillan was dismissive arguing that in an age of international organisations such as the North American Treaty Organisation and the United Nations, Britain's tradition of jealously guarding its sovereignty was irrational. ${ }^{350}$ Confident of his position, Macmillan even attacked traditional diplomacy by declaring that Britain's deliberate isolation from the continent during the nineteenth century had contributed to European instability during

\footnotetext{
${ }^{348}$ Harold Macmillan. "Full Text of Mr. Macmillan's Case for the Common Market," The Times, October 8, 1962.

${ }_{339} \mathrm{Ibid}$.

${ }^{350}$ Ibid.
} 
the twentieth century. ${ }^{351}$ Far from betraying the sacrifices made during two wars, the Conservative government was making a concerted effort to ensure that these men had not died in vain. British participation and leadership in Europe would help guarantee stability.

Membership in the EEC would also help to preserve the Commonwealth. Britain was the cornerstone of the organisation; through British strength the Commonwealth would thrive. ${ }^{352}$ Macmillan denied that Britain was faced with a choice between Europe and the Commonwealth and emphasised the bonds that tied the Commonwealth: blood, allegiance to the Crown and a common set of values. ${ }^{353}$ The economic links between Britain and the Commonwealth were weakening, but this did not imply that the family was going to disintegrate. The colonies had been granted political independence and this move had strengthened relations with the mother country; economic independence would not threaten this relationship. Rather, through participation in the Common Market, Britain would be able to build bridges between the Commonwealth and European countries.

The pamphlet was distributed to all delegates at the Conservative annual conference and made available to the general public for sixpence. The Times printed the text in full on October 8, the day it was distributed and the Daily Mirror printed the text over the course of three days. The Daily Mirror chose to print the text with photographs of British symbols of national identity such as Queen Elizabeth, the Palace of Westminster and the Lord Chief Justice, emphasising Macmillan's statement that Britain

${ }^{351} \mathrm{Ibid}$.
${ }^{352} \mathrm{Ibid}$.
${ }^{353} \mathrm{Ibid}$. 
would not be sacrificing its national identity in order to join the EEC. ${ }^{354}$ The newspaper also used bold fonts and headlines to emphasise that Britain had 'bright prospects' in Europe. The message was clear: British membership in the EEC would lead Britain into a prosperous future.

The Daily Mirror published an editorial cartoon by Stanley Franklin to demonstrate how Macmillan's pamphlet would clear the fog created by Gaitskell's speech and allow Britons to see clearly how closer links with Europe would be in Britain's best interest. The cartoon was split in two panes, both showed a young man, representing Britain, looking across the English Channel through a telescope labelled "Outlook to Europe." The upper pane showed the viewer looking through the wrong end of the telescope under Gaitskell's watchful eye. His image of Europe was severely distorted. On the bottom, Macmillan has appeared with his speech and turned the telescope around. Now the young man can see clearly how Britain's future will be affected by involvement in Europe. The cartoon suggested that Gaitskell manipulated the public in order to create opposition to British membership in the EEC. Macmillan's pamphlet, on the other hand, did not seek to manipulate; it

354 "Good Bye to the Past," Daily Mirror, October 17, 1962; "Our Obligations Would Not Alter the Position of the Crown, Nor Rob Our Parliament of its Essential Powers, Nor Deprive Our Law Courts of Their Authority in Our Domestic Life," Daily Mirror, October 18, 1962; "This Is No Time to Bury Our Heads in the Sand," Daily Mirror, October 19, 1962. 
sought to explain the facts clearly so that Britons could make an educated decision about the Common Market. Not surprisingly the Daily Mirror seized upon a work that supported its own point of view: Britons needed to look across the Channel in order to strengthen their nation.

The Guardian concurred with the belief that Europe was the future, claiming that Macmillan made a strong case for British membership. Being an outsider jeopardised Britain's intemational position. ${ }^{355}$ However, to the Guardian, the Conservatives appeared determined to bring Britain into the Common Market, regardless of the terms. This approach was unsatisfactory, as the paper pointed out once again, the terms negotiated would determine Britain's position within the new Europe. ${ }^{356}$ New terms were necessary not only to protect the Commonwealth, but also to ensure that Britain took a dominant role in the EEC.

The Daily Express agreed that Macmillan was determined to see Britain enter the Common Market. Unlike the Guardian, however, the Daily Express believed that Macmillan was in the process of destroying Britain. Macmillan claimed that Britain did not have to choose between the Commonwealth and the Common Market, "Britain would be the chief spokesman of the Commonwealth in Europe and the interpreter of Europe in the Commonwealth, reconciling the interests of these very different systems and acting as a bridge between them." 357 This position was contradicted by European leaders, Commonwealth leaders, his Cabinet and his previous statements. ${ }^{358}$ The Daily Express

\footnotetext{
355 "Mr Macmillan and Europe," Guardian, October 8, 1962.

${ }^{356} \mathrm{Ibid}$.

${ }^{357}$ Trevor Willis, "Macmillan Goes Into the Attack," Daily Herald, October 8, 1962.

358 "The Moon and Sixpence," Daily Express, October 8, 1962.
} 
called on conference delegates to see through Macmillan's claims and to protect the Commonwealth by standing firm for traditional Conservative values.

The Conservative debate on the Common Market took place on October 11 and the Party overwhelmingly endorsed the government's policy towards Europe. Proposed amendments to protect Commonwealth interests and to renegotiate the terms of membership were defeated by the delegates, although Cabinet members and Conservative leaders reiterated that "British policy is opposed to any extinction of national identity." 359 Delegates were told that Britons had no need to fear the Common Market since cooperation with Europe would strengthen the country. They were also reminded that membership in the EEC was not an inevitable step towards federation. ${ }^{360}$

Most newspaper reports on the Conservative debate emphasised the overwhelming support for British membership in the EEC. ${ }^{361}$ In the manner of Labour, the Conservative Party was united behind its leaders. Notwithstanding this support, many articles on the debate recorded the persistent difficulty that the Conservatives had in reconciling British membership in the EEC with its responsibility to the Commonwealth. While the opposition was silenced during the vote, clearly the Commonwealth was still a major concern for many Conservatives. ${ }^{362}$ In contrast, other papers such as The Times claimed that the Prime Ministers' meetings in September had relieved the Conservative

\footnotetext{
${ }^{359}$ Richard Austen Butler. "Address to the Conservative Party," October 11, 1962; Francis Boyd. "Support for Entry Into EEC," Guardian, October 12, 1962.

${ }^{360}$ John Hope, "Benefits of a United Europe," The Times, October 10, 1962.

${ }^{361}$ Hugh Picher, Ian Ross and James Render, "'Get Us In Quick' the Tories Tell Macmillan," Daily Herald, October 12, 1962; James Beecroft, "Mac Gets a Massive Yes on the 'Six'," Daily Mirror. October 12, 1962; "Rout of the Conservative Market Critics," The Times, October 12, 1962; Francis Boyd, "Support for Entry Into EEC," Guardian, October 12, 1962; William Greig, "Dazzling Ted Scatters the Tory Rebels," Daily Mirror, October 12, 1962.

${ }^{362}$ 'Hugh Picher, lan Ross and James Render, "'Get Us In Quick' the Tories Tell Macmillan," Daily Herald, October 12, 1962.
} 
fears that the Commonwealth would be harmed by the Common Market. ${ }^{363}$ The Guardian had an entirely different interpretation: the Conservatives had changed their priorities. They were willing to risk a "mortal blow" to the Commonwealth in exchange for the Common Market. ${ }^{364}$ The Commonwealth was finally losing its hold on the Conservative Party.

The question of the Commonwealth was an emotional one for the Daily Express, and the outcome of the conference led the newspaper to feel that the Conservative Party had abandoned its mandate to protect the nation's imperial legacy, demonstrating Macmillan's treasonous duplicity. The government had ceased to 'pretend' that Britain would not enter the EEC even if the terms were unfavourable; the Conservatives were surrendering to the Six. ${ }^{365}$ They had betrayed the cornerstone of their party and the nation: the Commonwealth and British sovereignty. Rather than defending Britain's imperial legacy, the Party had unquestioningly offered the country to a European federal state. $^{360}$ The Conservatives were supposed to be the guardians of traditional symbols of British identity: the Commonwealth, sovereignty of Parliament and the prosperity of the countryside. $^{367}$ Since the Conservatives were willing to join the EEC even at the cost of the Commonwealth, British sovereignty and the independence of the nation, the Daily

\footnotetext{
363 "The Fight is On," The Times, October 12, 1962.

${ }^{364}$ Francis Boyd, "Support for Entry Into EEC," Guardian, October 12, 1962.

${ }^{365}$ Alexander Kenworthy, "Heath Lays Mask Aside," Daily Express, October 9, 1962; Douglas Clark, "Now They're Hell Bent for the Market," Daily Express, October 12, 1962.

366 "For the Tories, A Call to Duty," Daily Express, October 11, 1962.

${ }^{367} \mathrm{Ibid}$. For the centrality of the countryside to constructions of national identity see Christine Berberich, "'I Was Meditating About England': The Importance of Rural England for the Construction of 'Englishness'," in History, Nationhood and the Question of Britain, eds. Helen Brocklehurst and Robert Phillips (Basingstoke: Palgrave Macmillan, 2004), 375-85.
} 
Express believed that they no longer had the right to sing "Land of Hope and Glory" at the end of their meetings. ${ }^{368}$

The leaders of the Conservative Party were to blame for the abandonment of its principles, according to the Daily Express. It believed that members of the Conservative Party were being frightened into supporting Macmillan's policies because the leadership had cast the debate over entry into Europe as one between political parties, not as an issue which, went to the roots of faith and patriotism." ${ }^{.369}$ British membership in the EEC would substantially alter the nature of the country's governance. The belief that Conservative delegates should support the Common Market, because it was party policy, removed their "inalienable right to decide their own destiny." 370 This attitude was characteristic of a totalitarian regime and the newspaper considered the Conservative Party's behaviour reprehensible.

On the day of the debate, 11 October 1962, the Daily Express printed a list of the pledges made by various Conservative leaders to protect the Commonwealth. ${ }^{371}$ Beside the list, a cartoon showed in descending order, Harold Macmillan, R.A. Butler, Duncan Sandys, Reginald Maudling, Peter Thorneycroft and Christopher Soames ripping up their pledges. They would no longer honour their words. The use of this cartoon reinforced the Daily Express's claim that the Conservatives

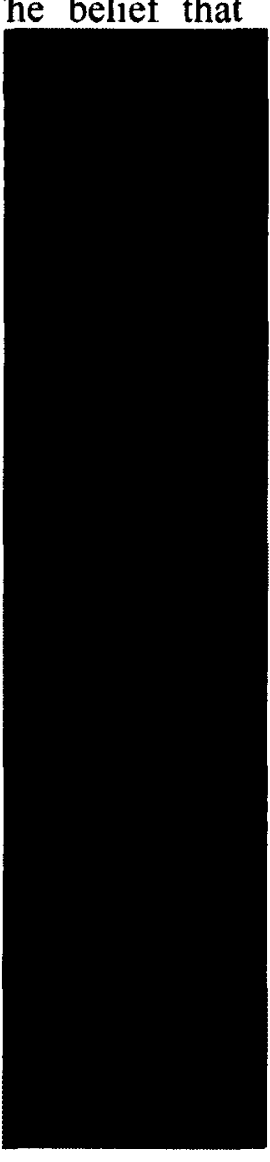

Figure 19 Daily Express, October 11, 1962

368 "Let the People Speak," Daily Express, October 12, 1962; "For the Tories, A Call to Duty," Daily Express, October 11, 1962.

${ }^{369}$ "For the Tories. A Call to Duty," Daily Express, October 11, 1962.

${ }^{370} \mathrm{Ibid}$.

371 "Speakers' Corner," Daily Express, October 11, 1962. 
were betraying Party values. While Conservatives sang "God Save the Queen" and professed loyalty to the Crown, they were surrendering British sovereignty, leading the Daily Express to warn that: "the Queen may stand more in need of saving from the Tories than from Labour." ${ }^{372}$ Conservative policy was threatening the heart of Britain and the Commonwealth: the monarchy.

Britain's betrayal by Conservative leaders was a recurring theme in the Daily Express's coverage of the conference debate and was clearly portrayed in a Michael Cummings' cartoon featured on October 12, 1962. The cartoon showed a delegate speaking out in support of the Commonwealth and against the Common Market while waving a Union Jack. Richard Austen Butler is seen whispering to Iain Macleod:

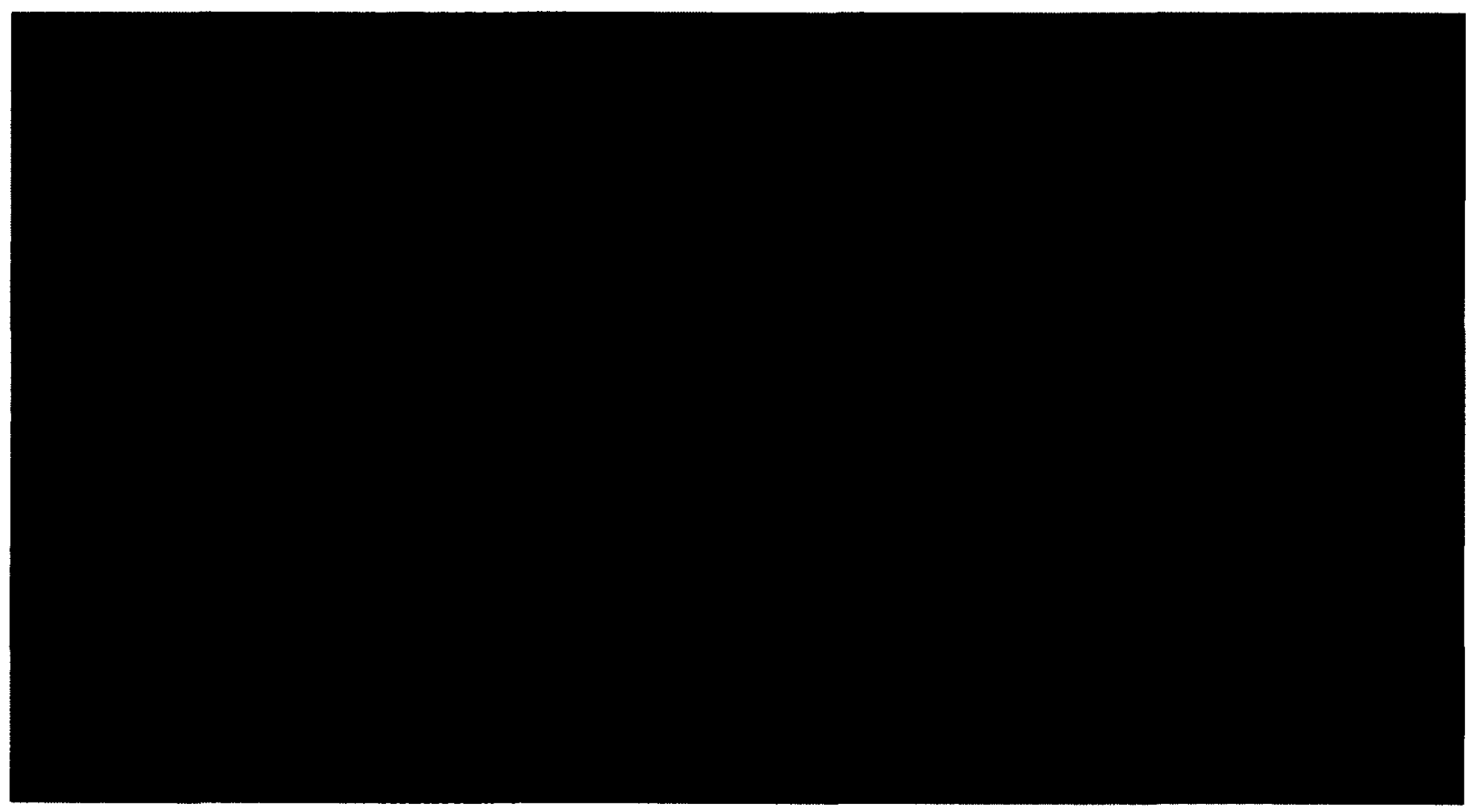

Figure 20 Daily Express, October 12, 1962

"[t]he fellow seems to think he's at a Conservative Party conference or something."

${ }^{372}$ Willian Barkley, "Stop Dawdling, Maudling," Daily Express, October 11, 1962.

${ }^{373}$ Michael Cummings, Cartoon, Daily Express, October 12, 1962. 
Behind the delegates a painting shows de Gaulle dressed as Britannia with the words "Europa, Europa, Europa rules the waves" written on the shield, while a banner decorating the hall reads "Land of Heath and Glory." Heath, the chief British negotiator for membership in the EEC is shown as wielding inordinate influence, directing British policy away from its traditional orientation and dragging the country into Europe.

Throughout its coverage of the Conservative debate, the Daily Express emphasised the threat to the Commonwealth posed by the Common Market. ${ }^{374}$ Europe was alien; not only were its inhabitants not British, but its values and traditions were unfamiliar and threatened the community of Britons that had been established during the past hundred years. Questioning why the Prime Minister would want to sweep away 'the tested and the true' for 'an alien theory', the Daily Express insisted that it was in Britain's best interest to maintain the familial relations that characterised the Commonwealth. ${ }^{375}$

Macmillan's speech to the delegates, delivered on October 13, countered the claim that Britain and Europe were distinct entities. He emphasised Britain's 'ancient' alliances with various continental powers, claiming that isolation from Europe had been a peculiar trait of nineteenth and twentieth century British foreign policy. ${ }^{376}$ Moreover, he reiterated his surprising claim that earlier British leadership in Europe might have avoided the two European wars of the twentieth century. In response to Gaitskell's appeal to remember the sacrifice of Commonwealth soldiers, Macmillan countered that

\footnotetext{
374 "What of the Cost to the Empire," Daily Express, October 12, 1962.

375 "For the Tories, A Call to Duty," Daily Express, October 11, 1962.

${ }^{376}$ Harold Macmillan, "Speech to the Delegates," 81st Annual Conservative Party Conference, Llandudno, October 13, 1962, in The Times, October 15, 1962.
} 
the sacrifice had been unnecessary and that Britain had a responsibility to ensure that young lives were not wasted on another war. ${ }^{377}$

Responding to the concerns about sovereignty, Macmillan reiterated that the Treaty of Rome was an economic treaty. Britons were not going to be deceived into joining a political union. ${ }^{378}$ Britain had already surrendered aspects of its sovereignty to international organisations such as NATO. If the country refused to accept modernity and insisted on clinging to the past, Britain would quickly be surpassed by the rest of Europe. The country needed to focus upon the future.

For the most part, the press responded to Macmillan's speech in the same manner that it had responded a few days earlier to his pamphlet. In spite of their approval for the government's policies, The Times and the Guardian pointed out that the Prime Minister's attitude towards the Commonwealth seemed inconsistent with traditional Conservative values. The Times claimed that Macmillan did not need to talk about the Commonwealth since the concerns of Conservatives had already been allayed at the conference. ${ }^{379}$ Conservative attitudes towards the Commonwealth had not changed, and the delegates were confident that the government's policy would not harm the organisation. The Guardian had a different interpretation of Macmillan's seeming lack of concern over the Commonwealth's future. The Prime Minister offered a new vision of the Commonwealth: it was not the Empire under a different name, but rather it was a new

\footnotetext{
${ }^{377}$ This belief can most likely be traced to Macmillan's experience during the First World War. Unlike Gaitskell who had been too young to serve, the Prime Minister had experienced the destruction of war first hand, and, like many of his contemporaries, he was determined to avoid another European war.

${ }^{378}$ Macmillan, "Speech to the Delegates."

${ }^{379} \mathrm{Ibid}$.
} 
and different entity. ${ }^{380}$ Europe would replace the Empire as a place of adventure for British youth. The Guardian continued to emphasise the generational aspect of the debate: older Britons were believed to be more committed to traditional symbols of Britishness such as the Commonwealth whereas the youth wanted the opportunities offered by Europe. ${ }^{381}$

Still, the Guardian repeated its warning that Britain should not join the EEC as a weak partner. Furthermore, the newspaper claimed that Britain needed to accept the inevitability of a federal Europe in order to take full advantage of the opportunities offered by European integration. ${ }^{382}$ The Daily Herald responded to Macmillan's speech with suspicion, believing that the Conservatives were responsible for Britain's stagnation, and that they had not become progressive simply because they were attempting to rush Britain into the Common Market. ${ }^{383}$ The Daily Mirror, however, was happy to support the Prime Minister's position. ${ }^{384}$ The Conservatives were now advocating for a "Land of Hope" rather than a "Land of [Previous] Glory" and Britons of all classes were finally starting to realise that they were "not (consistently) the cat's whiskers." 385 The Daily Mirror noted that since the Treaty of Rome had come into effect, Europe had surpassed Britain economically. If she continued in isolation, this trend would continue. Both The Times and the Guardian agreed that the Prime Minister was right to emphasise the need for a change in the nation's outlook. Contemporary Britain was characterised by "obsolete social attitudes" and if these were not abandoned, Britons would be unable to

\footnotetext{
${ }^{380}$ Francis Boyd, "Conservatives Taught a New Concept," Guardian, October 15, 1962.

${ }^{381}$ This argument was also common in the Daily Mirror. See "This is Why I Spoke Out for the Common Market," Daily Mirror, September 10, 1962 and the editorial cartoon from September 13, 1962.

382 "The Vision and the Statistics." Guardian, October 15, 1962.

383 "Holding Up Progress," Daily Herald, October 18, 1962.

384 "Not So Damn Simug!" Daily Mirror, October 16, 1962.

${ }^{385}$ Ibid.
} 
maintain their current standard of living. ${ }^{386}$ The world was transforming and both newspapers feared that Britain would soon be forced to accept the changes if it did not embrace them willingly.

Unsurprisingly, the Daily Express did not concur with the idea that the Commonwealth was unimportant or irrelevant, having previously published letters from young people that suggested its continuing importance. ${ }^{387}$ Interestingly, the newspaper did not mention Macmillan's speech. The Sunday Express, however, did publish cartoons by Cummings and Giles that responded to the Prime Minister's speech with familiar arguments on October 14, 1962. Cummings's cartoon showed Macmillan as a Trojan horse. Hiding inside was a Tory in tell tale

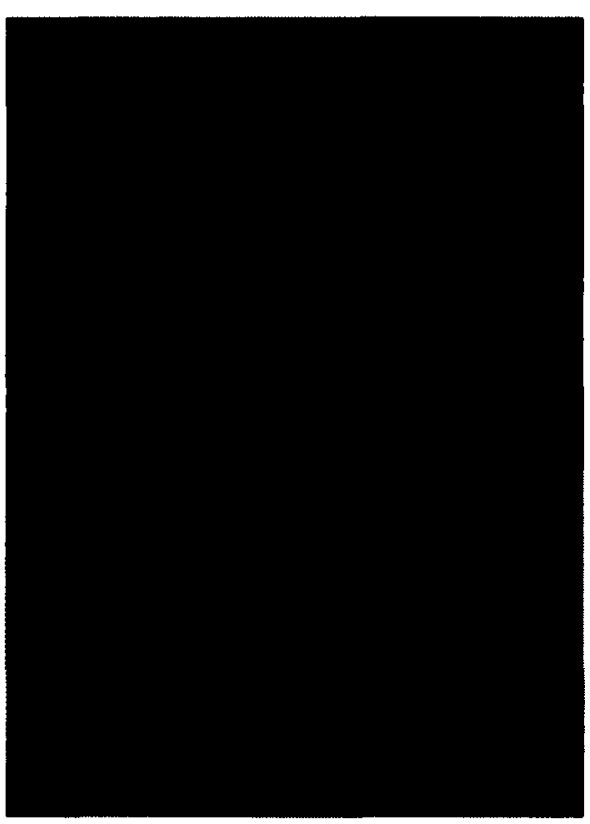

Figure 21 Sunday Express, October 14,1962 stripped trousers carrying a flag that read 'Federal Europe.' Macmillan might claim that the Conservatives would not bring Britain into a European federation, but he could not be trusted. If Britain joined the Common Market, it would not only lose its sovereignty, but would cease to be British. Britain would be overwhelmed with foreigners who did not understand or appreciate British traditions and symbols. By discarding Britain's glorious past, the Conservatives would ruin the country. In order for Britain to survive, the country had to hold fast. Since the Conservatives were no longer willing to fulfil their role as protectors of tradition, they would inevitably become irrelevant and lose their political power. The British people would not be deceived.

\footnotetext{
386 "Setting the Course," The Times, October 15, 1962.

387 "Under 25," Daily Herald, September 19, 1962.
} 
The setting of Giles' cartoon was Buckingham Palace and featured the changing of the guard. An Italian unit, accompanied by a monkey mascot, has arrived to take the place of the Palace guards. The sergeant responds by saying "I don't care if we are as good as in the Common Market - until we are, mate we still changa da guard at Buckingham Palace."

Figure 22 Sunday Express, October 14, 1962

If even Buckingham Palace and the changing of the guard would be threatened by the EEC, how could Britons hope to conserve their traditions under European overlords? The Daily Express warned that the Common Market was a direct threat to all things British.

The preservation of Britain's heritage was of prime importance to all those involved in the debate over membership in the EEC. Britain's international power and prestige needed to be repaired and conserved, for the country could not allow itself to descend into a subordinate position. All of the newspapers shared the assumption that 
Britain was destined to lead in the international sphere. The disagreement lay in how this role should be accomplished: through the Commonwealth or in Europe? Britain needed to maintain its civilising influence and remain involved in the process of moulding international values. This mission had been a mainstay of the British nationalistic vision throughout the imperial age and its relevance in the post-war period marked a distinct continuity in the construction of British national identity through most of the twentieth century. During both the Commonwealth Conference and annual political conferences, the debate was conducted using nationalistic imagery and appeals to collective pride. In fact, throughout September and October 1962, a marked escalation can be seen in the language used to discuss national identity. In September, the debate centred on the nature of the Commonwealth. Patriotic appeals were mostly reminders that Britain had more in common with the Commonwealth than with continental Europe. In this way, the idea that British civilisation extended beyond the physical boundaries of the United Kingdom was kept alive. Gaitskell raised the stakes by creating a dichotomy between Britain and Europe, grouping the Commonwealth countries together through shared traditions and values. Public discussions of his speech centred on the value of liberty, which encompassed freedom of political discourse. This freedom was repeatedly contrasted with continental Europe's history of dictatorship and tyranny. Finally, the language climaxed with Macmillan's speech and his use of the words "national identity" and his dismissal of fears that Britishness would disappear with European integration. ${ }^{388}$

Britain's international position had vastly altered by the mid-twentieth century, but public imagination remained focused on the glory days of Empire when the country

\footnotetext{
${ }^{388}$ Macmillan, "Speech to the Delegates."
} 
enjoyed great influence in world affairs. The Commonwealth held a good deal of appeal as a representation of British historical greatness and as a modern, multicultural family of nations. If the Commonwealth flourished as a cooperative association, it would provide an example to a divided world that peace in the midst of diversity was possible. Proponents of the Commonwealth hoped that Britain would be able to regain its international position through the triumph of British civilisation as a force for unity. British membership in the Common Market challenged this possibility.

Britons struggled with the idea of surrendering sovereignty, especially in the field of foreign affairs. European leaders, especially President de Gaulle of France and Chancellor Adenauer of the Federal Republic of Germany, were watching Britain carefully. Not only did Britain have to decide if she wanted to join Europe; Europe had to decide whether it wished to allow Britain into the club. The British debate over the continued relevance of the Commonwealth was viewed, particularly by the French, as a litmus test to judge whether Britons were willing to become European. French newspapers watched the Commonwealth Conference and resulting debate closely throughout September 1962. 


\section{Chapter: The Europeanization of Britain in the French Press}

The EEC members carefully watched Britain's deliberation over its national identity. From the date of the application, continental European newspapers questioned whether Britain wanted to be a European or a Commonwealth power. ${ }^{389}$ Would attachment to the Commonwealth interfere with Britain's commitment to the Common Market? Membership in the EEC would require changes to Commonwealth trade, and Europeans were uncertain whether Britain would agree to such terms.

The questioning of Britain's Commonwealth connection was visible in continental newspapers. In the political cartoons of the De Groene Amsterdammer, the Dutch cartoonist Opland echoed the familial theme found in the British press to represent

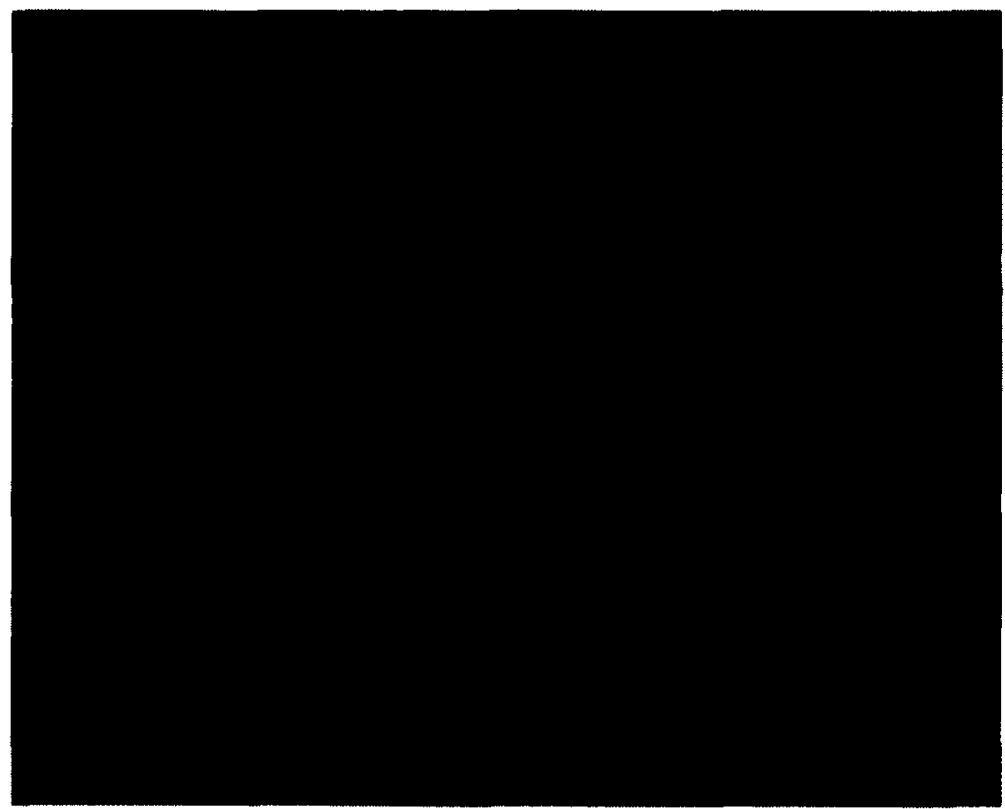

Britain's relationship with the Commonwealth. In a cartoon published in August 1962, he portrayed Britain as a mother unwilling to leave her children behind in order to join the EEC. She tells Paul-Henri Spaak and Jan Willem de Pous, "I'll

Figure 23 Cartoon by Opland on British membership in the EEC join if my kids can join (August 4, 1962)

${ }^{384}$ See Jean LeCerf, "La candidature britannique soulève le problème de l'équilibre politique dans le Marché commun," Le Figaro, September 26, 1961; Libero Lenti, "Ingresso in Europa," Corriere della Sera, August 1, 1961; Elly Staegmeyr, "Europas grösserer Markt." Süddeutsche Zeitung, August 3, 1961. 
too! ${ }^{\ominus 390}$ Another figure, most likely de Gaulle, covers his eyes in exasperation at Britain's entourage. The continuing allegiance of Britain to the Commonwealth and the imperial family was a major obstacle to participation in the Common Market. German cartoonist Fritz Behrendt captured Britain's dilemma incisively in his cartoon in Die Weltwoche. ${ }^{391}$ Macmillan was portrayed as Faust caught in an internal struggle, because Britain is simultaneously a Commonwealth and a European country, and has "two souls [that] live in [his] heart."

Figure 24 Cartoon by Behrendt on British membership in the EEC (September 1962)

Of the continental countries, the French watched the Commonwealth meetings with particular interest, as the Conference coincided with the end of the Algerian War

${ }^{390}$ Opland. Te kijk bij Opland: een serie politieke spotprenten wit de Volkskrant (Utrecht: De lanteern, 1964) on European NAvigator, accessed February 13, 2011, http://www.ena.lu. Both Spaak. a Belgian politician and 'founding father' of European integraton and de Pous, the Dutch economic minister, favoured British membership in the EEC.

${ }^{391}$ Fritz Behrendt. Trotzalledem, Eine Auswahl von 100 politischen Karikaturen. Rotterdain: Nijgh \& van Ditmar, [s.d.] European NAvigator, accessed February 13, 2011, http:/www.ena.lw/. See also Augusto Guerriero, "Che farà de Gaulle," Corriere della Sera, August 9. 1962 for an example from the Italian press. This cartoon was republished in the Observer on September 23, 1962 and can be found at the British Cartoon Archive http://www.cartoons.ac.uk/record/18109. 
and the start of Algerian independence. Akin to England, France also experienced the problem of decolonisation and the need to redefine its identity. ${ }^{392}$ By 1962 , France had abandoned the idea that Algeria was French, but only after a bloody eight year war. A hundred years of "l'Algérie, c'est la France" had impressed the centrality of empire and Algeria, in particular, on French identity. Changing the foundation of French identity would prove no easier than changing that of the British. ${ }^{393}$ While France faced a visible symbol of the dissolution of its empire, the British Commonwealth insisted on perpetuating its association with the mother country. As a result, the French held a particular interest in the changing nature of the relationship between Britain and her old colonies. $^{394}$ In fact, Le Monde made a deliberate comparison between Algeria and Rhodesia, and in late September, the newspaper stated that some in Britain feared that Rhodesia would be Britain's Algeria. The result was a binary that established France as the opposite of British liberal values. ${ }^{395}$ The idea that Britain might also face a war with one of its colonies would challenge the assumption that the French and British were fundamentally different, and that France was the opposite of British liberal values.

The dissolution of the British and French empires proceeded in quite distinct ways and produced different results. ${ }^{396}$ For the most part, Britain's relations with its old

${ }^{392}$ Krishan Kumar, "English and British National Identity," History Compass 4, no. 3 (2006): 428.

${ }^{393}$ See Etienne Balibar, "Algeria, France: One Nation or Two," in Giving Ground: The Politics of Propinquity, eds. Ariel Azoulay et al. (London: Verso, 1999); Yves Michaud, ed., La guerre d'Algérie (1954-1962) (Paris: Odile Jacob, 2004); Todd Shepard, The Invention of Decolonization: The Algerian War and the Remaking of France (Ithaca, N.Y.: Cornell University Press, 2006), particularly "Introduction," and "Part One: The Making and Forgetting of French Algeria."

394 Henri Pierre, "Les questions d'Afrique Noire," Le Monde, September 26, 1962. "Les travaillistes anglais craignent que la situation en Rhodésie du Sud n'évolue vers une crise " de type algérien "."

${ }^{395}$ Colley, Britons, xxi. Colley argues that British national identity was primarily defined in terms of Britain's relationship with France.

${ }^{396}$ Britain and France both experienced decolonisation during the mid-twentieth century, although their experiences were very different. Britain escaped the long and bloody wars that characterised French 
colonies remained cordial, if somewhat strained, and official trade links remained intact. ${ }^{397}$ Observers in the 1960 s, especially in France, were keenly aware that a number of British colonies were in no hurry to claim complete independence from their old colonial masters: President de Gaulle argued that Britain was not prepared to be a truly 'European' nation, but rather preferred to continue its close Commonwealth relations. ${ }^{398}$ This concern over Britain's loyalties reflected the longstanding tradition of Anglo-French rivalry.

In addition to the complex and competitive relationship of Britain and France, potential British membership in the EEC threatened the Franco-German power bloc that de Gaulle hoped to forge. De Gaulle gave eloquent expression to the perceived seriousness of this threat by fostering - with no shortage of determination - a personal relationship with the German Chancellor, Konrad Adenauer. ${ }^{399}$ The Franco-German

decolonisation in Algeria and South East Asia. As a result, in comparing British and French decolonisation historians have often concluded that Britain was more successful in withdrawing from empire. The reasons given for Britain's successful decolonisation vary, but many historians suggest that British imperial govemance was better suited to accept and facilitate colonial independence. As a result, the transition between colony and independence was smooth and even encouraged by British policy. Recent work. however, has questioned this conclusion. The process of British decolonisation was not always peaceful or necessarily embraced by the British government. Racial conflict in southern Africa, the Suez Crisis and the Malayan Einergency all challenge the idea of a peaceful transition from colonial to national government in the British Empire. See Tony Smith, "A Comparative Study of French and British Decolonization," Comparative Studies in Society and History 20, no. 1 (Jan. 1978); Henri Grimal, La decolonisation de 1919 à nos jours (Brussels; Éditions complexes, 1985); Robert Holland, "The British Experience of Decolonization," Itinerario 20, no. 2(1996); A.J. Stockwell, "A Widespread and Long-Concocted Plot to Overthrow the Govermment in Malaya?' The Origins of the Malayan Emergency," in Emergencies and Disorder in the European Empires After 1945, ed. Robert Holland (London: Frank Cass \& Co., 1994); Wm. Roger Louis, "The Dissolution of the British Empire," in Oxford History of the British Empire: The Twentieth Century, eds. Judith Brown and Wm. Roger Louis (Oxford: Oxford University Press. 1999).

397 David George Boyce, Decolonisation and the British Empire, 1775-1997 (London: Macmillan Press, 1997), 183; Ronald Hyam, Britain's Declining Empire: The Road to Decolonisation, 1918-1968 (Cambridge: Cambridge University Press, 2007), 400.

${ }^{398}$ De Gaulle claimed that "if Great Britain cannot enter unreservedly into the Common Market, it should not enter at all." Quoted in Maurice Vaïsse, "De Gaulle and the British 'Application' to Join the Common Market," in Britain's Failure to Enter the European Community, 1961-1963, ed. George Wilkes (London: Frank Cass \& Co.. 1997), 52.

${ }^{399}$ See Charles de Gaulle. Mémoires d'espoir. tome I: Le renouveau (1958-1962) (Paris: Plon, 1970), 191-2. 
rapprochement proceeded apace throughout 1962, crowned by Adenauer's visit to Paris in July and de Gaulle's visit to Bonn in September. ${ }^{400}$ British membership in the Common Market threatened France's hold on power, because Britain was as powerful, economically and politically. ${ }^{401}$ For de Gaulle, Britain would be far more difficult to control than the smaller nations of Europe.

De Gaulle's aversion to Britain was no secret and gave the French press much fodder for its columns. For this study, two newspapers representing contrasting political perspectives have been chosen to examine the debates in the French press over British membership in the Common Market. Le Monde generally adopted a centre-left perspective, whereas Le Figaro represented the centre-right. Both newspapers had a reputation for political discussion, making them excellent sources to examine the French public discourse concerning Britain's future in the EEC. ${ }^{402}$ In September 1962, both Le Monde and Le Figaro tended to concentrate on three aspects of the debate; Britain's relationship with Europe, the changing nature of Britain's relationship with the Commonwealth, and Britain's future role in European integration. Unlike the British press, Le Monde and Le Figaro argued that before Britain could obtain membership in the EEC, links with the Commonwealth had to be severed. Both newspapers believed that Britain would eventually participate in European integration, but expressed doubts

\footnotetext{
${ }^{400}$ De Gaulle's visit to Bonn coincided with the arrival of the Commonwealth Prime Ministers in London. British newspapers placed the two events side by side, emphasising the historic significance of Franco-German rapprochement. See Daily Express, September 5, 1962; Daily Mirror, September 10. 1962; Guardian, September 7, 1962.

${ }^{401}$ John W. Young, "Britain and the EEC, 1956-73: An Overview," in From Reconstruction to Integration: Britain and Europe Since 1945, eds. Brian Brivati and Harriet Jones (London: Leicester University Press, 1997), 106.

${ }^{402}$ Raymond Kuhn, The Media in France (London Routledge, 1995), 66-7.
} 
over whether the British were ready at this point to trade their imperial identity for a European one.

While Le Monde and Le Figaro engaged in the debate over the nature of British identity and its compatibility with a developing European identity, Britain and the Commonwealth were not given prominence in September 1962. Other matters were of greater concern to the French public, namely Franco-German relations (especially de Gaulle's visit to Bonn), developments in Algeria, and the coming legislative elections. Articles on the Commonwealth Conference rarely featured on the front pages. ${ }^{403}$ In the case of Le Figaro, for example, they were found in the "Foreign News" section alongside news from countries such as the United States, Egypt, and Spain. ${ }^{404}$ This placement emphasised the foreignness of Britain. In contrast, important news from Germany and other members of the Six featured primarily on page two alongside domestic news.

In September 1962, the Commonwealth Conference and Britain's possible membership in the Common Market occupied regular column space in both Le Monde and Le Figaro. Throughout the Conference, each newspaper featured daily updates, as well as editorials and articles that examined either Britain's place in Europe or its relationship with the Commonwealth. Both newspapers recognised that Britain had to placate the Commonwealth, which was the fundamental problem when considering Britain's future in the EEC. Le Figaro recognised that the Commonwealth represented a large portion of the world's population and, as a result, its concerns could not be

\footnotetext{
${ }^{403}$ For the first three days of the conference Le Monde's placed its reports on the front page. Afterwards, the conference was relegated to the foreign news section.

${ }^{404}$ See for example Le Figaro September 24, 1962 or Le Monde, September 12, 1962.
} 
ignored. $^{405}$ The newspaper believed, however, that its character and role were in transition. The Commonwealth was not a monolith and did not present a united front during the meetings. ${ }^{406}$ Its members all had different agendas and pursued their own national self-interest. According to Le Figaro, the Commonwealth was once a family, but now, it had become a club whose interactions followed the rules of international relations. ${ }^{407}$ The type of symbiotic relationship between metropole and periphery that characterised the imperial age was no more. National and regional identities replaced and surpassed imperial identity. Le Figaro republished a William Papas cartoon that summed up its view of the situation. ${ }^{408}$ The cartoon showed Macmillan begging at the feet of de Gaulle and Adenauer, while the Commonwealth lion, prodded by Gaitskell, attempted to pull him back.

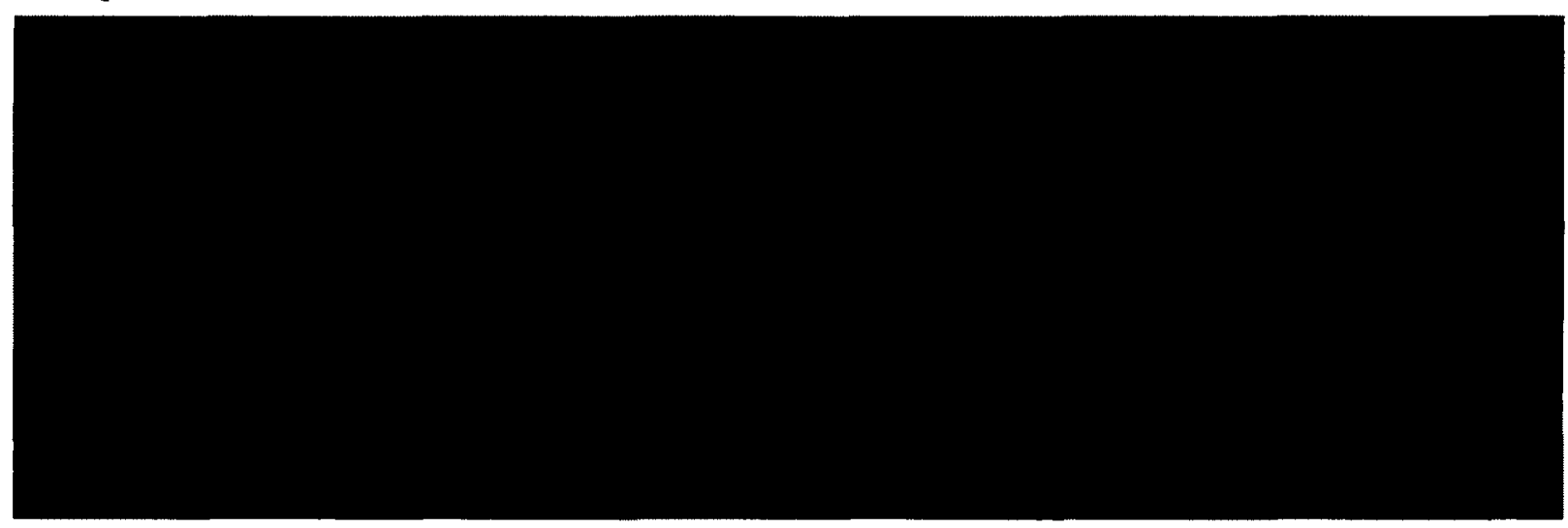

Figure 25 Le Figaro, September 19, 1962

The Commonwealth and its supporters, represented by Gaitskell, would inhibit British membership in the EEC, not because of the importance of imperial trade links, because of

405 The newspaper pointed out that the Commonwealth leaders represented 15 countries and 685 million people. "15 pays, 685 millions d'hommes sont représentés," Le Figaro, September 11, 1962.

${ }^{406}$ Pierre Bertrand, "Le Canada, l'Inde, l'Australie...ont exposé leurs appréhensions face au Marché commun," Le Figaro. September 13, 1962.

${ }^{407}$ Pierre Bertrand, "La candidature de la Grande-Bretagne au Marché commun au cour des débats," Le Figaro, September 11, 1962.

${ }^{408}$ The Guardian originally published the cartoon on September $13^{\text {th }}$. 
the centrality of this imperial symbol to British identity. Both the British and French press recognised that the debate over the Common Market was not primarily over economic policy, but rather over identity.

Le Figaro argued that Britain continued to view itself as peripheral to Europe, emphasising in one headline that many Britons believed that "Great Britain is not part of Europe." ${ }^{409}$ This belief that Britain was fundamentally different from continental Europe would hinder British membership in the EEC, since EEC members had to be first and foremost, European. According to Le Figaro, Britons - who had grown comfortable in their role as leaders of a great Empire - refused to accept their new position as partners in Europe. Le Figaro pointed out that Britain must join the EEC, not expect the Common Market to join Britain. ${ }^{410}$ Commonwealth trade relationships would be compromised with British membership of the EEC, but these historic links would need to be sacrificed in order for Britain to become a part of the new Europe. Le Figaro echoed the same arguments made by the pro-Market Daily Mirror: Britain would have to choose between its imperial past and a future in Europe.

Le Figaro was confident that Britain would come to the realization that its future lay in Europe and that the imperial past had to be relinquished, but this would take time. If the current British application failed, it would be because of Britain's lack of readiness for Europe and not because Europe rejected Britain. ${ }^{411}$ According to Le Figaro, de

\footnotetext{
409 "Les agriculteurs britanniques: La Grande-Bretagne ne fait pas partie de l'Europe," Le Figaro, September 5, 1962.

410 "Le Industriels Contonniers: C'est l'Angleterre qui doit entrer dans le Marché Comımun," Le Figaro, September 6, 1962.

41 Joseph Alsop, “Vers l'Europe avec la Grande-Bretagne," Le Figaro, September 18, 1962.
} 
Gaulle had "no intention of vetoing British membership." ${ }^{\text {412 }} \mathrm{He}$ simply insisted that Britain would not be granted special conditions of entry. Britain should enter under the same terms as every other member of the Common Market, which included the growing momentum towards political integration. ${ }^{413}$ Since integration was the future, Britain's good sense would overcome its apprehensions and its romantic attachments to the remnants of the British Empire.

In September 1962, however, Le Monde concluded that the Commonwealth's power over the British imagination was a more potent force than its trade relationships. ${ }^{414}$ Le Monde believed that integration was the potential solution to many of the problems Europe faced in the twentieth century. While the newspaper recognised the difficulties inherent in Britain's new orientation towards Europe, Le Monde claimed that the role of the Commonwealth was also changing, and that as it increased in size, the old imperial connection would weaken. ${ }^{415}$ After examining the data, the newspaper pointed out that trade between the old Dominions and Great Britain was declining, whereas trade with the United States and Japan was on the increase. ${ }^{416}$ Of course, this change did not suggest that Commonwealth trade links were inconsequential, especially for its newer members. British entry into the Common Market would affect trade agreements and would require a realignment of trade networks.

Le Monde believed that as Britain's former colonies exerted their independence, Britain's participation in Europe would increase. The newspaper assumed that the

412 Ibid. "...le générale le Gaulle n’a jamais eu l'intention de tenir la Grande-Bretagne hors de l'Europe par l'effet d'un veto de la France seule."

413 Ibid.

414 "Les anglais à l'écoute," Le Monde, September 8, 1962.

415 "Les pays du Commonwealth devant l'entrée de la Grande-Bretagne dans le Marché commun," Le Monde, September 11, 1962.

${ }^{416}$ Ibid. 
imperial metropoles formed a distinct community from the peripheries, demonstrating a fundamental difference between Le Monde and the British press. It was the view of Le Monde that Britain would inevitably fall under Europe's influence because of geographical proximity, whereas newspapers in Britain naturally grouped the Commonwealth together, mixing the 'old' and 'new' worlds into a community based on shared language, traditions and values.

Both Le Monde and Le Figaro recognised that Britain's cultural ties to the Commonwealth were the most difficult to sever. Le Figaro reported that the debate over the Common Market was dominated by the countries whose economies were the least dependent on the Ottawa Agreements. ${ }^{417}$ These countries had no economic or political associations with Britain, yet they preserved the Commonwealth tie and saw it as important. This insistence on the centrality of the Commonwealth revealed the depth of the cultural and emotional connections between Britain and the most successful Dominions, which were mostly populated by British settlers.

Yet Le Figaro depicted the continuing relevance of the Commonwealth in British economic and political policies as anachronistic. The reason that Commonwealth concerns were so fundamental lay in the British public's continued loyalty to the Empire, which revealed a fundamental weakness. Le Figaro reported that the opponents of the Common Market were gaining ground in British public opinion. Reprinting a poll from the Daily Mail, the numbers showed that 37.8 percent supported British membership in

\footnotetext{
417 Pierre Bertrand, “Le Canada, l'Inde, l'Australie...ont exposé leurs appréhensions face au Marché commun," Le Figaro, September 13, 1962.
} 
the EEC, whereas 52.2 percent were opposed and 10 percent were undecided. ${ }^{418}$ The public's ambivalence and hostility towards European integration would be an important barrier to British participation in the EEC. Britain's alliances and allegiances had to be re-orientated so that the people recognised that their political and economic future lay in Europe.

Le Monde admitted that this process would be complicated by the Britishness of the Commonwealth. One of the features in Le Monde in early- to mid-September 1962 was a travel series that focused on the British colonies in the Far East and Indian subcontinent. The first article in the series was entitled "Hong Kong: England in China." ${ }^{, 419}$ The articles emphasised the Britishness of these colonial outposts: they might be located in Asia, but their heart and soul was British. ${ }^{420}$ This claim echoed the language used in the Guardian's series on New Zealand, and these articles reinforced the argument that Britain was not yet ready to consider itself European. The idea of a greater community spread throughout the world still held too great a hold over the collective imagination of Britons.

The real significance of the Commonwealth Conference, according to Le Monde, was the impact that Commonwealth opposition had on the British public's support for

\footnotetext{
418 "En Angleterre les adversaires du Marché commun gagnent du terrain," Le Figaro, September 12. 1962

\$19 "Hong Kong: Angleterre en Chine," September 6, 1962.

${ }^{420}$ Interestingly at the same time Le Monde published a series of articles that examined the French colonies of the Antilles. These articles emphasized the Frenchness of the Antilles and the close relationship between France and its colonies in the Caribbean. The Antilles were not interested in independence nor were they interested in close relations with former French colonies in Africa; rather they looked to preserve and protect their symbiotic relationship with the France. Philippe Decraene, "La Martinique et le mythe de l'indépendance," Le Monde, September 11, 1962. This article was published on the first page of the newspaper's September $11^{\text {th }}$ issue, and situated immediately underneath an article on Macmillan's refusal to compromise over Britain's future in the EEC. The September $13^{\text {th }}$ issue featured articles on both the smaller French Antilles on page 5 and British India on page 13. Successful French colonies were given predominance over the old "crown jewel of the British Empire."
} 
European integration. The newspaper highlighted Gaitskell's role in the debate over the Common Market. While the leader of the Labour Party might claim neutrality, Le Monde detected a growing antagonism towards British membership in the EEC. ${ }^{421}$ The denunciation of the Brussels terms by Commonwealth labour leaders, Le Monde believed would galvanise public opinion. Gaitskell's claim that the Macmillan government was too hasty in its negotiations would raise Britons' doubts about the wisdom of his European policy. ${ }^{422}$ Gaitskell might be unwilling to condemn publicly the British application to join the Common Market, but his opposition was becoming increasingly clear.

Le Monde's emphasis on the importance of Gaitskell in the debate was in contrast to Le Figaro's coverage, which afforded the Labour leader little mention. Although the Conservatives held power in Britain, the newspaper clearly believed that the Labour Party had a great deal of influence over public opinion. As a centre-left newspaper, Le Monde would have been more sympathetic to the Labour Party, a centre-left political party than the centre-right Le Figaro. Still Le Figaro's dismissal of the Labour Party is peculiar. In the 1959 election, the Labour Party had received 43.8 percent of the vote, while the Conservatives had received 49.3 percent. ${ }^{423}$ Labour clearly enjoyed extensive support from amongst the British public. As well, Hugh Gaitskell enjoyed great personal

\footnotetext{
${ }^{421}$ Pierre, "M. Macmillan n'entend pas."

422 Pierre, "M.Macmillan demand aux premiers ministres."

$\$ 23$ Jessica Yonwin, UK Election Statistics: 1918-2004 (Westminster: House of Commons Library, 2004), 9. $\quad$ accessed $\quad$ October 2, http://www.parliament.uk/documents/commons/lib/research/rp2004/rp04-06l.pdf.
} 
popularity. ${ }^{424}$ Politics aside, his charisma and conspicuous presence in British political life gave him great influence in the debate over the Common Market.

Gaitskell had clearly stated that Macmillan had to ensure the protection of the Commonwealth. Le Monde believed that Gaitskell's continued attachment to the ideals of the Commonwealth was shared by much of the British public. The airing of concerns and the threat that the Commonwealth might not survive if Britain joined the Common Market could potentially turn public opinion against British membership in the EEC. According to Le Monde, this should be the concern of the Macmillan government: the Commonwealth Prime Ministers were unable to directly affect British policy, but their words and actions would influence the public.

Like Le Figaro, Le Monde believed that the British public's continued attachment to the Commonwealth was outdated and weakened Britain. The newspaper questioned whether Macmillan could risk entering the Common Market with a divided country. ${ }^{425}$ If a majority of Britons turned against the Common Market, they might force an election over British membership in the EEC, especially since Gaitskell had already called for a general election before the final decision was made. ${ }^{426}$ The newspaper implied that such an action would be a mistake, since the ensuing election would be fought on the basis of a sentimentalised idea of the glorious British Empire rather than on the reality of post-war trading relationships. ${ }^{427}$ The British public's continued sentimental attachment to the

${ }^{424}$ Brian Brivati, Hugh Gaitskell (London: Richard Cohen Books, 1996), 418.

${ }^{425}$ Pierre. "Les premiers ministres du Commonwealth."

${ }^{426}$ Pierre, "M. Macmillan n'entend pas," Le Monde, September 13; "M. Gaitskell demande des élections générales avant tout engagement définitive dans l'Europe des Six," Le Monde, September 15. 1962.

${ }^{427}$ Pierre, “M. Macmillan n'entend pas," Le Monde, September 13, 1962. 
Commonwealth was problematic enough; to squander Britain's economic and political future in Europe over a fading ideal was ludicrous.

Le Monde was also critical of Britain and the Commonwealth's reaction to the Franco-German rapprochement, reading it as indicative of Britain's ambivalence towards European integration. After two world wars, a Franco-German reconciliation met with applause, but many in Britain feared the ramifications of a close relationship between de Gaulle and Adenauer. ${ }^{428}$ The Commonwealth was already suspicious of the Common Market, a concern expressed specifically by the three Dominions of Canada, Australia, and New Zealand. European political integration would only serve to heighten these fears, leading many to conclude that British sovereignty would be subsumed into the supranational institutions of the EEC.

Although Le Monde believed that British participation in the integration project was fundamental for its future success, the newspaper recognised that British membership in the EEC would threaten France's position within the EEC, since Britain could easily dominate the association, by shifting the focus of the EEC from a European regional power bloc to an Atlantic-focused association. ${ }^{429}$ Le Monde recognised the importance of de Gaulle's rapprochement with Adenauer in preserving and protecting the European identity of the Common Market. ${ }^{430}$ The continued importance of the Commonwealth in British economic and cultural life, and Britain's Atlantic outlook meant that the European character of the EEC could be diluted by British ascendancy. Britain was not European enough to take the predominant role.

\footnotetext{
428 "Les anglais à l'écoute," Le Monde, September 8, 1962.

${ }^{429}$ Ibid.

${ }^{430}$ Ibid.
} 
Le Figaro also criticised Britain's suspicions of the Franco-German rapprochement. In September, the newspaper launched a series on "United Europe and the World," written by Raymond Aron. ${ }^{431}$ The series claimed that while the United States supported Europe's integration, other nations - particularly those from the Commonwealth - feared the power of a united Europe. ${ }^{432}$ Many countries believed a Franco-German power bloc would undermine the Atlantic Community. For his part, Aron did not believe that British membership in the EEC would be forthcoming since the British press, was effectively misrepresenting France's intentions and turning the negotiations into a battle between France and Britain. ${ }^{433}$ Aron held that de Gaulle was not anti-British, but he was concerned that Britain was not prepared to accept the next stage of integration, namely, eventual political union. .

Aron's assumptions about the nature of British identity were manifest in the language that he used to describe Britain. The article employed an interesting binary of "European" and "British" when discussing possible British membership in the EEC. A clear distinction existed between Britain and Europe. While Aron hoped that someday Britain would become European, the British were too attached to their Empire at present. ${ }^{434}$ He believed that it drew them away from Europe by competing for loyalty and by making British identity tied to Atlantic rather than European relationships. In order for Britain to truly join Europe, these allegiances must fade and Britain must show

${ }^{431}$ Raymond Aron, "L'europe unie et le monde," Le Figaro. September 1, 1962; September 2, 1962: September 4, 1962. Aron was a French intellectual and journalist who wrote extensively on politics and international relations in the post-war period. Interestingly, he was also one of the first intellectuals to call for Algerian independence, arguing that colonialism was no longer economically viable. Shepard, 68.

432 Aron, September 1, 1962.

${ }^{433}$ Raymond Aron, "L'europe unie et le monde: Les " six » et la Grande Bretagne," Le Figaro. September 4, 1962.

${ }^{434}$ Aron, "Les 'Six' et la Grande Bretagne." 
itself committed to Europe above all else. Only then would Britain truly become a "European" nation.

Similar to that of Aron and Le Figaro, the language used by Le Monde revealed its assumptions about British identity and Britain's role in Europe. Throughout its coverage of the Commonwealth Conference, the newspaper used the term "Europe" as a synonym for the EEC. ${ }^{435}$ This usage promoted a hierarchy of European nations that were either truly "European" or peripheral. The Six topped this hierarchy and Le Monde's associated them as "European". The nations behind the Iron Curtain were members of a different bloc, while the Scandinavian and Iberian countries had occupied the peripheries of Europe's self-identification throughout the nineteenth and early twentieth century. ${ }^{436}$ With the exception of the Soviet Union, European countries that were not members of the EEC were mostly minor powers that had limited influence on the world stage. Britain did not fit this rubric; its deliberate omission as a "European" nation is indicative of an assumption that British identity was incompatible with European identity. Britain's own reluctance to define itself contributed to the French view of the country. Membership in the EEC would be part of Britain's transformation into a truly European nation.

Aron's series also condemned the British press for its role in the public discourse on European integration. The British press blamed de Gaulle for difficulties in the negotiations and presented a growing Franco-German axis concentrated on de Gaulle

\footnotetext{
${ }^{435}$ For example: Pierre, "Les premiers ministres du Commonwealth." "M. Macmillan pourrait-il alors, sans risque, entrer en Europe;" "Le président du Pakistan propose au général de Gaulle d'élargir le Marché comnun aux dimensions du Commonwealth," Le Monde, September 15, 1962. "...M. Macmillan et le général de Gaulle puissent entièrement négliger ce qu'on ne peut à vrai dire appeler un projet mais plutôt un appel et plus exactement encore un avertissement à l'Europe."

436 Patrick Salmon, Scandinavia and the Great Powers. 1890-1940 (Cambridge: Cambridge University Press, 1997), 22; Francisco J. Romero Salvadó, Twentieth-Century Spain: Politics and Society in Spain, 1898-1998 (Basingstoke: Palgrave, 1999), 4.
} 
and Adenauer as the most pressing external obstacle to British membership in the EEC. ${ }^{437}$ Aron - and by extension the French press - defended the President, claiming that the problems in negotiations were caused by Britain's misgivings about the future of European integration beyond the Common Market. Actually, both the British and the French press were correct in their assumptions. De Gaulle's distrust of the British was well-known, and he did fear that his vision of European unity would be hindered by Britain which opposed political integration and jealously guarded its sovereignty in the negotiations. $^{438}$ The attitudes of both the British and French presses revealed mutual prejudice and assumptions about the nature of Anglo-French relations and identities that went far beyond government policies.

While both Le Monde and Le Figaro agreed on many aspects of the 'British problem'- Britain's outdated attachment to the Commonwealth, the need to accept regional blocs and the importance of Franco-German rapprochement - there were important differences between the two newspapers' interpretations of the debate. Most telling were the roles assigned de Gaulle and the British press in determining Britain's future. While Le Figaro was highly defensive of de Gaulle, Le Monde rarely mentioned the French President's personal views on British membership in the EEC. Throughout

${ }^{437}$ This attitude was particularly evident in the cartoons. See, for example, Franklin's cartoon in the Daily Mirror on September 6 and the caption under the Daily Herald's reprint of a cartoon from the German newspaper Koelnische Rundschau. Both feature the marriage celebration of France and Germany and point out the deliberate exclusion of Britain from the festivities, insinuating that Britain was not welcome in the new Europe. See appendix A.

${ }^{438}$ Peter A Daly, "The First British and Danish Applications to Join the EEC, 1960-63," in Britain and Denmark: Political, Economic and Cultural Relations in the 19th and 20th Centuries, eds. Jorgen Sevaldsen, Bo Bjørke and Claus Bjør (Copenhagen: Museum Tuscullanum Press, 2003), 595; .N. Piers Ludlow, Dealing with Britain: The Six and the First UK Application to the EEC (Cambridge: Cambridge University Press, 1997), 209. Adenauer was also becoming increasingly unsure about British membership because of his suspicions of the Atlantic community and fears that British membership would "dilute the Continental character of the community." Ronald Granieri, The Ambivalent Alliance: Konrad Adenauer, the CDU/CSU, and the West, 1949-1966 (New York and Oxford: Berghahn Books, 2003), 155. 
the 1960s, Le Monde was often critical of de Gaulle's policies and deliberately kept a certain distance from the French government. ${ }^{439}$ Rather than criticise the British newspapers for vilifying the President as Le Figaro did, Le Monde chose to applaud the Daily Mirror and the Financial Times for their attempts to influence the British public's view of European integration. ${ }^{440}$ According to Le Monde, these two newspapers were among those in Britain attempting to convince the public that the future rested in Europe. The government needed to embark on a campaign to educate the public as to changing realities. Britain needed to redefine itself as a European nation.

Those Britons who were committed to the Europeanisation of their country emerged as heroes in Le Monde and Le Figaro. Macmillan was particularly lauded for his courage and diplomacy. As the Conference opened, Le Figaro predicted that Macmillan would require all of his diplomatic skills in the coming days. Not only would he need to reassure the Commonwealth, but he would also need to find a way to reconcile the various divergent concerns of Commonwealth leaders with his own government policy. ${ }^{41}$ Le Figaro, however, was confident that Macmillan would be able to reach a compromise. $^{442}$ Even when this hope was dashed by strong Commonwealth opposition to the Common Market, the British Prime Minister maintained his firm commitment to

439 Elisabeth Le, Editorials and the Power of Media: Interweaving of Socio-cultural Identities (Philadelphia: John Benjamins Pub. Company, 2010), 3; "The Press: As Le Monde Turns," Time, December 26, 1969.

${ }^{4+40}$ Pierre, "M. Macmillan demande aux premiers ministres."

441 "Conférence du Commonwealth ouverte par M. Macmillan," Le Figaro, September 10, 1962.

442 Pierre Bertrand, "Le Solution de compromis envisagée sur le problème du Marché commun," Le Figaro, September 15, 1962. 
European integration. ${ }^{443}$ Britain needed more men with Macmillan's visionary outlook on Europe if British attitudes towards the continent were to be refashioned.

Le Monde believed that Macmillan recognised both the changing nature of international relations and the future role of Europe. ${ }^{444}$ Throughout its coverage of the Commonwealth Conference, the newspaper emphasised Macmillan's determination to see Britain join the EEC. Macmillan's strength of character was a reoccurring theme, and Le Monde repeatedly stated that the Commonwealth recognised that the final decision rested with the British Government. ${ }^{445}$ The conference was an opportunity for the Commonwealth to air its grievances and discuss its concerns, but it would not challenge British government policy. All of the participants recognised that Britain alone must make this decision.

As the Commonwealth Conference closed, Le Monde began to refer to British membership in the EEC as "the construction of Europe" ${ }^{446}$, implying that Britain's embrace of Europe would complete the EEC's roster of European powers. Still, Le Monde recognised that no clear winner had emerged from the conference and that Macmillan still faced many obstacles in his quest to bring Britain into the Common

\footnotetext{
${ }^{443}$ Pierre Bertrand, "Assaut final aujourd'hui de M. Macmillan dans les débats du Commonwealth sur le Marché commun," Le Figaro, September 17, 1962.

444 "Londres prépare activement la conférence du Commonwealth." Le Monde, September 3, 1962; “M., Macmillan va affronter les chefs des gouvernements du Commonwealth," Le Monde, September 6. 1962.

${ }^{445}$ Henri Pierre, "M. Macmillan n'entend pas laisser remettre en cause sa politique d'adhésion a l'Europe des Six," Le Monde, September 11, 1962; Henri Pierre, "M. Macnillan demande aux premiers ministres du Commonwealth une neutralité bienveillanté à la défaut d'un soutien positif," Le Monde, September 12, 1962; Henri Pierre, "Les premiers ministres du Commonwealth ont violemment attaqué les intentions de M. Macmillan mais semblent résignés à le laisser agir," Le Monde, September 13, 1962: Henri Pierre, "La conférence du Commonwealth s'achemine vers sa conclusion dans un clinat de résignation," Le Monde, September 16-17, 1962.

${ }_{446}^{42}$ Le Monde, September 19, 1962; Le Monde, September 19, 1962. "La construction européenne."
} 
Market. $^{447}$ The battle over Britain's future was still in progress. Words such as "confrontation," "battle," "vanquisher" and "vanquished" emphasised the combative nature of Commonwealth relations over British membership in the Common Market. ${ }^{448}$ The British application to join the EEC had revealed divisions within the Commonwealth, illustrating fundamental weaknesses that would eventually lead Britain to embrace European integration.

According to Le Monde, the Conference placed Macmillan in a good position to effect change in Britain's self-image. Many of the Commonwealth countries wanted another meeting after the terms of membership were clearer, but the conference closed with no guarantee of a future meeting before Britain joined the EEC. Macmillan still had "his hands free" with regards to the Common Market. ${ }^{449}$ The newspaper emphasised the need for the Prime Minister to embark on a campaign to bolster public support for British membership in the EEC, especially given Gaitskell's seeming opposition to the Common Market. ${ }^{450}$ The British public needed to be educated in order to appreciate the changing nature of international relations. Their outdated attachment to the Commonwealth was a remnant of the imperial system of the nineteenth century; the realities of the post-war world meant that Britain needed to become a full partner in Europe. No longer could the country thrive while maintaining its distance from the continent. The British people needed to accept that they were first and foremost Europeans.

\footnotetext{
${ }^{448}$ Ibid. Henri Pierre, "M. Macmillan s'est battue jusqu'au bout," Le Monde, September 20, 1962. "Apres une dure " bataille du communiqué »." September 21, 1962.

449 "M. Macmillan garde les main libres pour reprendre les négociations de Bruxelles," Le Monde,

${ }^{450}$ Henri Pierre. "M. Macmillan plaide sans restriction la cause de l'entrée dans l'Europe," Le Monde, September 22, 1962; "M. Gaitskell réclame des élections générales et suggère la remise en cause des accords de Bruxelles," Le Monde, September 23-24, 1962.
}

447 "La conférence du Commonwealth s'est achée sans vainqueurs ni vaincus," Le Monde, September 20. 1962. 
At the end of September 1962 Le Figaro predicted that the balance of the autumn would prove decisive in Macmillan's battle for public opinion. The newspaper believed that the coming "by-elections and political conferences will reveal the nature of British public opinion on the Common Market." ${ }^{\text {451 }}$ If the Conservatives lost seats in the November by-elections, Macmillan's leadership would be challenged and this would complicate his attempts to promote the Common Market. ${ }^{452}$ Furthermore, Le Figaro predicted that both the Labour and Conservative Party conferences would be dominated by the debate over British membership in the EEC. The Conservative Party conference, in particular, would be a test of both Macmillan's leadership and his vision of Britain's future as a European nation. ${ }^{453}$ The members of the EEC would soon know whether Britons were willing to embrace Europe and a European identity, or if they would continue to be wedded to their imperial past.

Throughout its coverage of British-Commonwealth relations, Le Monde focused primarily on the process and the impact of Britain adopting a European focus and identity. Even after the close of the Commonwealth Conference, the newspaper continued to publish daily articles on Britain's metamorphosis from an imperial to a European power. Le Figaro was less interested in this process, and after the publication of the communiqué, it was even less engaged in the problems of Britain and the

45I Pierre Bertrand, "Sérieuses échéances d'automne pour M. Macmillan," Le Figaro, September 29, 1962. "Élections partielles et congrès politiques permettront de prendre la tenpérature de l'opinion anglaise à l'égard du Marché commun."

452 This belief was quite common in 1962. In the South Dorset by-election of November 1962, the intervention of an anti-Common Market candidate split the Conservative vote and allowed Labour to win this previously safe Conservative seat. At the time, it was suggested by some who opposed EEC membership that this election result was indicative of growing anti- Europeanism. In a recent article, N. J. Crowson challenged this view, claiming that the Conservative campaign was dominated by local issues and the by-election was not a vote against the EEC. N. J. Crowson, "Lord Hinchingbrooke, Europe and the November 1962 South Dorset By-election," Contemporary British History 17, no. 4 (Nov. 2003): 43-64.

${ }^{453}$ Bertrand, "Sérieuses échéances." 
Commonwealth, although the newspaper continued to point out that the Commonwealth was no longer the close imperial family of the early twentieth century. In particular, trade relationships were changing, and the United States and Europe were becoming more important trading partners for most Commonwealth nations. ${ }^{454}$ Very little, however, was mentioned about the possible outcomes of the Conference. One article summarised the final communiqué and another included a brief description of Macmillan's speech, but with the conference over, the newspaper directed its attention elsewhere. $^{455}$

Both newspapers, however, did maintain their interest in the effects of European integration on the developing world, particularly Africa. The concern over Africa revealed the continuing relevance of European imperial ideologies. Le Monde and Le Figaro encouraged Britons to abandon their romantic attachments to the British Empire, while still firmly attached to imperial paternalism. The Common Market was a threat to ex-colonial economies that remained tied to the markets of its former-metropole. In the case of the Commonwealth, Le Monde conceded that measures would be needed in order to ensure that their economies were able to cope with the realignment of British markets. ${ }^{456}$ Le Monde's particular concern over African countries may reflect France's interests in the area. Many of France's African colonies had only recently been granted independence; they were still in the process of establishing themselves. Furthermore

\footnotetext{
454 "L'Europe et les Etats-Unis : Marchés en expansion pour le Commonwealth," Le Figaro. September 21, 1962

455 "Feu vert a Macmillan," Le Figaro, September 20, 1962; "Nouveau et importants sondages de M. Heath," Le Figaro, September 22-23, 1962. The only other mention of Britain's application was a brief paragraph explaining that negotiations for the British entry to the EEC would resume in October. "Reprise des négociations C.E.E. - Grande Bretagne : Pas avant le 8 octobre," Le Figaro, September 20, 1962. Le Figaro was more concerned with the elections in Algeria and the possibility of European political union.

456 "Comment réorganiser l'espace économique africain?" Le Monde, September 23-24, 1962.
} 
during the Cold War, African countries were thought to be especially vulnerable to communism, since a number of northern African nations received Soviet arms and military assistance. ${ }^{457}$ France provided aid to many of its foreign colonies in order to counter and contain Soviet influence. Ensuring African economic stability would help to stop the spread of communism in Africa.

Le Monde suggested that the EEC should take the lead in reorganising the African economic sphere, championing an association of African states with strong trading links to the EEC. Europeans had divided up the continent in the nineteenth century; now they had the responsibility to help reform its economic structure. The continuing Commonwealth trade relationships meant that there were, in essence, two African economies. Commonwealth countries maintained much of the old imperial trade patterns rather than forging new regional links. ${ }^{458}$ Now the nations of Europe, including Britain, had a responsibility to help facilitate both regional trading blocs and African global trade. British membership in the Common Market would aid in the reformulation of Africa's economy since Britain's 'global influence' would allow the EEC to effect real change. ${ }^{459}$

British membership in the EEC could, however, also bring new challenges to an association between Europe and Africa. According to Le Monde, this challenge was to be found in the nature of Britain's relationship with Africa as Britain's ex-African colonies feared European economic intervention represented a re-imposition of colonialism. ${ }^{460}$ Le

\footnotetext{
${ }^{457}$ Henri Pierre. "Les premiers ministres du Commonwealth accepteraient la poursuite des négociations de Bruxelles," Le Monde, September 18.1962.

458 "Comment réorganiser l'espace économique africain?"

${ }^{459}$ Ibid. "L'Angleterre, avec sa position mondiale..."

${ }^{460}$ One of the proposals for easing African concerns over British membership in the EEC was to grant associate membership to the African Dominions, the same arrangement that had been made to protect French colonial interests. Nigeria was hesitant to accept such an arrangement, believing that such a status
} 
Monde argued that Britain's reorientation as a European power and its proposed participation in the Common Market meant that African Commonwealth countries would need assistance in order to reformulate their economies during a transition period while international relations were reorganized along regional, rather than imperial, lines. ${ }^{461}$

In contrast to Le Monde, Le Figaro's imperial ideology appeared in the newspaper's coverage of Indian Prime Minister Nehru's visit to Paris. While Le Monde stressed Nehru's belief in the flexibility of the Commonwealth, by focusing on how the organisation had changed in the post-war period, ${ }^{462}$ Le Figaro was more interested in the relationship between France and India. The newspaper emphasised that the two countries shared mutual respect, ${ }^{, 463}$ and that Nehru and de Gaulle could work together in order to ensure that the interests of the entire Indian subcontinent were protected. ${ }^{464}$ Le Figaro emphasised that France understood and respected India's concerns. The newspaper was confident that de Gaulle would ensure that India would be protected upon Britain's entry into the Common Market.

The emphasis on India is important for several reasons. First, India played an important role in international relations as one of the largest and most powerful members of the non-aligned movement. India had refused to take sides in the Cold War, and Western leaders were anxious to ensure that the Soviets did not gain influence. ${ }^{465}$ More

threatened its independence and undermined its hard won sovereignty. "Nigeria Against Even Associate Membership of EEC." The Times, September 5, 1962.

461 "Comment réorganiser l'espace économique africain?"

${ }^{462}$ Henri Pierre, "La souplesse du Commonwealth réduit les risques d'une véritable rupture," Le Monde, September 21, 1962.

463 "Première journée à Paris de M. Nehru," Le Figaro. September 21, 1962.

164 "Nehru a invité de Gaulle en Inde," Le Figaro, September 24, 1962.

${ }^{465}$ One of Le Figaro's articles focused on Nehru's foreign policy, emphasising that the Indian Prime Minister was not sympathetic towards communism. "Nehru reçu par le général de Gaulle aujourd'hui a l'Élysée," Le Figaro, September 22-23, 1962. 
importantly, however, India had been the 'crown jewel' of the British Empire. France and Britain had both established colonies in India, but by the late nineteenth century France had ceded most of its Indian colonial holdings. ${ }^{466}$ Now Le Figaro emphasised that France would protect Indian interests. De Gaulle took on a paternalistic and imperial role, replacing, in a sense, India's British protector. While the theme of Anglo-French imperial competition is subtle, its continuing relevance suggests that France's difficulty in accepting Britain's continuing imperial identity may have been because of the lasting legacy of its own empire. French national identity had also been based on an imperial ideal; in protecting India and other developing nations, France was able to claim a sort of paternal role that was reminiscent of the nineteenth-century civilising mission.

France, like Britain, had difficulty shedding its imperial past. Throughout the nineteenth and early twentieth centuries, France had self-identified as an imperial power, drawing much of her international prestige from her empire. Decolonisation in the postwar period had altered the foundation of French international relations, necessitating the construction of a new basis for identity. European integration had provided France with a new focal point for discussions of national identity, but decades of imperial identity were difficult to erase. A new basis for national identity would require the French people to alter their new way of thinking, a process that could only be accomplished gradually. In

\footnotetext{
${ }^{466}$ For an interesting historical interpretation of the Anglo-French battle over India see Edward James Rapson, The Struggle Between England and France for Supremacy in India (London: Trübner \& Co, 1887).
} 
1962, this change was still ongoing and many of the assumptions of the imperial paradigm were still in place. ${ }^{467}$

The French press's interest in Britain's relationship with the Commonwealth reflected the continuing importance of imperial concepts in French public discourse. Britain was also undergoing a fundamental challenge to its assumptions concerning national identity. Unlike the French, the British Empire appeared to be transitioning into a post-colonial association of states. France's fear that Britain was not yet prepared to abandon its imperial past may have reflected continuing Anglo-French imperial competition. To equate French uncertainty over the British application to join the EEC with an historic rivalry, however, obscures other factors. Le Monde's insistence that Britain needed to accept its role as a European power was also, in part, a reminder to its French readers that France was also primarily a European, rather than an imperial, power. The changing nature of the Commonwealth was a reminder that the age of European imperialism had drawn to a close.

The post-war period was a time of transition and transformation in international affairs. Both France and Britain faced similar challenges in a post-imperial age, and both began to look to Europe in order to find a new international role. French ambivalence towards British participation in the Common Market reflected much of the country's own insecurities and fears concerning British competition. These fears manifested themselves in the suggestion that Britain was not yet ready to leave the Empire behind, echoing many of the Daily Mirror's claims that the British public was living in the past rather than

467 See Kristin Ross Fast Cars, Clean Bodies: Decolonization and the Reordering of French Culture (Cambridge, Mass: MIT Press, 1995); Shepard, The Invention of Decolonization: Michaud, La guerre d'Algérie. 
embracing the future. ${ }^{468}$ The French press believed that Britain would eventually recognise that its destiny lay in Europe rather than the Commonwealth, but both Le Monde and Le Figaro believed that Britons were not yet able to see themselves as fully European. When Britain accepted its place as a European power, it should be welcomed into the EEC. Until that time, however, Britain's hesitancy towards European integration meant that the country could not participate in the Common Market.

${ }^{468}$ See John Beavan, "It's War on Two Fronts," Daily Mirror, September 20, 1962; Cassandra, "I Hear the Tramp of History Pass Us By," Daily Mirror, October 4, 1962; "Not So Damn Smug!" Daily Mirror, October 16, 1962; "Good Bye to the Past," Daily Mirror, October 17, 1962 


\section{Chapter: Conclusions}

Britain's first attempt to join the Common Market ended on January 14, 1963 when General de Gaulle effectively vetoed further negotiations. The French president claimed that membership in the EEC was based on equal treatment for all: Britain's insistence on special terms of entry went against this policy. ${ }^{469}$ Britain, according to de Gaulle, was not a true European nation:

England, in effect, is insular, she is maritime, she is linked through her exchanges, her markets, her supply lines to the most diverse and often the most distant countries; she pursues essentially industrial and commercial activities, and only slight agricultural ones. She has in all her doings very marked and very original habits and traditions. In short, England's nature and structure differ profoundly from those of the continent. ${ }^{470}$

The economic structures of Britain and the Continent differed greatly. Many of the EEC's policies were agricultural. The fact that Britain's economic interests lay in overseas trade and industry caused de Gaulle to question how two divergent economic principles could be reconciled. More importantly, however, the French President pointed out that Britain's nature was different than that of continental Europe.

Arguably this difference grew out of Britain's economic ties to Commonwealth countries. De Gaulle pointed out that membership in the EEC meant that Britain had to

\footnotetext{
${ }^{469}$ Charles de Gaulle, "Confërence de presse du 14 janvier 1963 (sur l'entrée de la GrandeBretagne dans la CEE)" accessed October 18, 2011, http://www.ina.fr/fresques/de-gaulle/fichemedia/Gaulle00085/conference-de-presse-du-14-janvier-1963-sur-l-entree-de-la-grande-bretagne-dans-lacee.html.

${ }^{470}$ Ibid. "L'Angleterre, en effet elle, est insulaire. Elle est maritime. Elle est liée par ses échanges. ses marchés, ses ravitaillements aux pays les plus divers, et souvent les plus lointains. Elle exerce une activité essentiellement industrielle et commerciale, et très peu agricole. Elle a dans tout son travail des habitudes et des traditions très marquées, très originales. Bref, la nature, la structure qui sont propres à l'Angleterre diffèrent profondément de celle des continentaux."
} 
"to renounce all Commonwealth [trade] preferences." ${ }^{471}$ The continuing economic role of the Commonwealth was symptomatic of a larger problem: the political and economic reality of the British Empire might be fading, but it continued to play an important cultural role in Britain. The British public believed that the Commonwealth represented a 'family' centred on Britain and the Queen. De Gaulle believed that Britons were not yet ready to embrace a European identity, believing that their imperial history not only distinguished them from the Continent, but also linked Britain to a larger global community.

De Gaulle's assumptions about Britain's reluctance to let go of the past echoed throughout British and French newspaper coverage of the Commonwealth Conference in 1962. This conference, called to discuss the implications of British membership in the EEC, demonstrated the continuing importance of the Commonwealth to British national identity. The political party conferences that followed in October further reinforced the sustained relevance of the Empire in public discourse in Britain during the post-war period because all three parties were forced to address concerns raised by the Commonwealth leaders. The Empire was gradually disappearing, but Britons still believed that a wider British community existed, characterised by a shared history of imperial achievements and a set of common values.

De Gaulle claimed that Britain was not yet ready to join the EEC, but allowed for the possibility that "that one day England might manage to transform herself sufficiently

${ }^{471} \mathrm{Ibid}$. "De renoncer à toutes préférences à l'égard du Commonwealth." The economic importance of the Ottawa Agreements had declined, but they were still an important barrier to a common European tariff. 
to become part of the European community."472 This assertion was echoed in both Le Figaro and Le Monde. The two French newspapers agreed that Britons were not prepared for EEC membership, but asserted that Britain was in the process of becoming European. Britain's continued commitment to the Commonwealth and the British public's emotional attachment to the Empire interfered with the country's ability to truly integrate with continental Europe. In order for Britain to become a European nation, the country and its people would need to divest themselves of the imperial remnants that continued to influence British policies. Britain could not be both an Atlantic and a European power; the British would have to choose between their past and a future in Europe. In 1962, however, neither Le Figaro nor Le Monde believed that the British public would support membership in the EEC at the cost of the Commonwealth.

The Common Market did enjoy widespread support amongst segments of the British public at the time of the Commonwealth Conference. With the exception of the Daily Express, all of the British newspapers analysed supported membership in the EEC. Nonetheless, they all maintained a traditional interpretation of Britain's international role. Britain was destined to lead the world. For example, according to the Daily Mirror, the Commonwealth was no longer the vehicle that would allow Britain to maintain its leadership position, so the country needed to look to Europe to ensure that it continued to exercise its rightful role. The newspaper reiterated the need for Britons to let go of the past and to embrace the future. If Britain insisted on maintaining an outdated system based on past glories, the country would miss out on the possibilities of the future. There was nothing inherently wrong with the Commonwealth, but it was an association whose

\footnotetext{
${ }^{472}$ Ibid. "Alors il est possible qu'un jour, l'Angleterre parvienne à se transformer elle-même suffisanment pour faire partie de la Communauté européenne sans restriction..."
} 
strength was fading. According to the Daily Mirror, Commonwealth links had to be weakened and its members needed to embrace regional blocks. Holding on to the past would only harm the individual members.

The Daily Herald, The Times and the Guardian were less willing to discount the Commonwealth, recognising that many of their readers still believed in its relevance. Instead, they insisted that Britain needed to maintain its economic and political strength in order to ensure the vitality of the Commonwealth. Membership in the EEC did not threaten the Commonwealth's survival; in fact, British participation in the Common Market would ensure that the association continued to thrive. All three newspapers reassured their readers that the Commonwealth was thriving and that the Common Market was not a threat. The Commonwealth's prestige and influence was directly tied to that of Britain. Since the EEC would increase Britain's economic stability, the Commonwealth would benefit from a stronger centre.

The Daily Express, self proclaimed guardian of the Empire, disagreed with the assertion that the Common Market would strengthen rather than threaten the Commonwealth. Beaverbrook's newspaper focused on the political implications of joining the EEC, claiming that Britain would be unable to maintain its Commonwealth links while participating in the Common Market. The country would be forced to choose. Selecting Europe meant subordination to France and most importantly, abandoning the Commonwealth, Britain's children. According to the Daily Express, Britain had spread its civilisation through the Empire and now had a responsibility to ensure that this community continued. As a multinational, multiethnic organisation, the Commonwealth 
represented the best of British imperialism, something that united Britons around the world. Nothing could be allowed to threaten its pre-eminence.

Each British newspaper participated in the process of community building using common language and shared assumptions to identify members of 'Greater Britain.' Throughout the coverage of the Commonwealth Conference and its aftermath, familial language was ubiquitous. The Commonwealth was a 'family', that held 'mother' Britain dear. Depending on the newspaper, Commonwealth nations were 'daughters' or 'cousins'. The use of family imagery reinforced the bonds between its members, while simultaneously downplaying the tensions that plagued the Commonwealth. ${ }^{473}$ A family might disagree and drift apart, but it remained bound to a shared heritage. Citizens of the Commonwealth continued to constitute a community that had grown out of British institutions and values. While its membership spoke different languages and came from different cultures, the Commonwealth was, at its heart, a British family, further reinforcing the myth of peaceful decolonisation.

In addition to employing language that reinforced imperial identity, the newspapers also upheld ideas about British identity through the use of shared symbols and experiences. All five newspapers that were studied assumed that members of the British community would recognise references to the Charge of the Light Brigade, 'Hope and Glory' and the Somme. The Queen and Parliament embodied Britain's political values that were shared throughout the Commonwealth. The symbols referenced were mutual signifiers for all Britons and many harkened back to the Empire. As a result, the

\footnotetext{
473 One of the most important tensions in 1962 was over racial policies in Africa. The Commonwealth was still dealing with the fallout from South Africa's withdrawal in 1961 over its condemnation of apartheid. Ronald Hyam and Peter Henshaw, The Lion and the Springbok: Britain and South Africa since the Boer War (Cambridge: Cambridge University Press, 2003), 304.
} 
newspapers could make indirect reference to the continuing importance of the Commonwealth as a symbol of British national identity. The use of symbols strengthened the centrality of the Commonwealth through the invocation of ideas directly and indirectly tied to the imperial history shared by all Britons.

This assumption of common experience was especially visible in the political cartoons published in September and October 1962. They depended upon the immediate visual recognition of the character, symbols and situations depicted. For instance, Britannia was the most frequent representation of Britain. While the use of a female personification of Britain may have predated the British Empire, Britannia was a potent symbol of Empire throughout the nineteenth and early twentieth century, having grown in popularity after Victoria's accession to the throne in $1837 . .^{474}$ The use of this image deepened the continuity between the high days of Empire under Victoria and the decline in the aftermath of World War II. Britannia represented more than just the island of Great Britain. She embodied British values, traditions and history, with each entangled in concepts of the Empire. The cartoons also made heavy use of a lion labelled "Commonwealth." The use of the image underlined the family bond since the lion served as a common animal representation of Britain. The Commonwealth and Britain could both be represented by the British lion. The cartoons contained different interpretations of the EEC, but all maintained the essential Britishness of the Commonwealth and the importance of the Empire to British identity.

The fate of the Commonwealth and its importance continued to dominate the debate over Britain's relationship with Europe. While Britain applied for membership in

\footnotetext{
${ }^{474}$ Martin J. Wiener, Men of Blood: Violence, Manliness and Criminal Justice in Victorian Britain (Cambridge: Cambridge University Press, 2004), 4.
} 
the EEC again in 1967, it was not until 1973 that the country finally joined the Common Market in its first enlargement. ${ }^{475}$ British public opinion, however, remained divided over membership in the EEC. When the Labour Party came to power in 1974, Prime Minister Harold Wilson sought a renegotiation of the terms of entry. Future governments would continue to waver over their commitment to European integration. ${ }^{476}$

The hesitancy and ambivalence that characterized Britain's attitude towards European integration in its early years continued to be reflected in British policy towards Europe even after its admission to the EEC. Debates in the press, such as those over agricultural produce standards, the European monetary union and the 2010/2011 Greek financial crisis, have ensured that Britain's place in an integrated Europe remains a matter of dispute. $^{477}$

The explanation for this contention may continue to lie in Britain's imperial legacy. Discussions of British national identity still bear the imprint of the British Empire. ${ }^{478}$ Much of British nationalism continues to draw on a mythic past of an Empire when Britannia ruled the waves. With devolution and the rise of Welsh and particularly Scottish nationalism, the continued viability of Britain as a nation has been questioned, leading to a nostalgia for the glorious days when the island of Great Britain ruled over a

\footnotetext{
${ }^{475}$ Charles de Gaulle, "Conférence de presse du 27 novembre 1962," http://www.ina.fr/fresques/ de-gaulle/fiche-media/Gaulle00139/conference-de-presse-du-27-novembre-1967.html De Gaulle vetoed British membership in the EEC for a second time in 1967. using Britain's devaluation of the sterling as a reason to block the application.

476 Stephen George, "The Awkward Partner: An Overview," in From Reconstruction to Integration: Britain and Europe Since 1945, eds. Brian Brivati and Harriet Jones (Leicester: Leicester University Press, 1993), 179.

${ }^{47}$ See for example "The Euro's Time of Reckoning," The Economist, May 2010; Ian Drury, "Campaign to bring back curvy cucumber grows as EU comes under pressure to relax rules on sale of 'imperfect' fruit and veg," Daily Mail, October 28, 2008.

${ }^{478}$ Stuart Ward. "The End of Empire and the Fate of Britishness." in History, Nationhood and the Question of Britcin, ed. Helen Brocklehurst and Robert Phillips (New York: Palgrave MacMillan, 2004), 254.
} 
quarter of the world's population. ${ }^{479}$ Many Britons continue to fear that European integration is an attempt by continental Europe to destroy not only British national identity, but also the British nation and its historic achievements.

Britain may have joined the EEC in 1973, but many Britons were and continue to be uncomfortable with being European. Britain's desire to retain its influence in Churchill's concentric circles has been manifest in its attempts to act as a mediator between the United States and the European Union. While British policy has not always concurred with that of the Americans, Britain has largely kept its close relationship with the United States. ${ }^{480}$ Anglo-American military cooperation remains important for both countries, and Britain has worked hard to maintain a balance between Europe and the United States. While some critics of the 'special relationship' have warned against becoming too dependent on the Americans, Britain continues to seek a balance between its Atlantic and European connections. ${ }^{481}$

The current British press feeds public belief in the fundamental difference between Britain and Europe, and is commonly thought to be fiercely Eurosceptic. ${ }^{482}$ The debate in the press revolves around questions of national identity, invoking the idea that European integration is opposed to the interests of the British nation. The key

${ }^{479}$ Antoinette Burton, "When Was Britain? Nostalgia for the Nation at the End of the 'American Century" "Journal of Modern History 75 (June 2003): 359.

${ }^{480}$ Mary Troy Johnston, "Britain and Transatlantic Security: Negotiating Two Bridges Far Apart," in Old Europe, New Europe And The Us: Renegotiating Transatlantic Security In The Post 9/11 Era, eds. Tom Langsford and Blago Tashev (Ashgate: Aldershot, 2004), 42.

${ }_{481}$ Jolinston, 45.

${ }^{482}$ According to the Economist columnist Charlemagne, the majority of British newspapers receive their European Union news from Open Europe, which he calls "a small, but assiduous Eurosceptic campaign group." Charlemagne, "Spoonfeeding Lazy Journalists: Open Europe: the Eurosceptic group that controls British coverage of the EU," Economist, March 31, 2010. 
assumption is the belief that Britain is not European. ${ }^{483}$ Accusations abound that the current move towards European political integration is really a Franco-German plot to threaten Britain's sovereignty and security by an advancing European 'superstate' which would subsume London to Brussels. ${ }^{484}$ These accusations feed fears that European integration threatens Britain's survival not only as a sovereign political entity, but also its unique position as intercessor between Europe and the United States.

Constructions of British separation from Europe are also found in both popular and academic interpretations of British history. Ambivalence towards the project of European integration is institutionalized in the British educational system. Classes offered in British history focus primarily on pre-1945 periods, emphasizing Britain's history as a great imperial power. In primary school, the National Curriculum states that students should be taught "aspects of the histories of England, Ireland, Scotland and Wales, where appropriate, and about the history of Britain in its European and wider world context, in these periods." 485 The European context, however, is limited to "a study of the way of life, beliefs and achievements of the people living in Ancient Greece and the influence of their civilisation on the world today." ${ }^{486}$ British primary school children are required to study the Anglo-Saxons, the Tudor era and either Victorian or twentieth century Britain, while their study of Europe is limited to ancient Greece.

\footnotetext{
${ }^{483}$ Oliver Daddow, "Euroscepticism and the Culture of the Discipline of History," Review of International Studies 32, no. 2 (2006): 316.

${ }^{484}$ Peter J. Anderson, "A Flag of Convenience? Discourse and Motivations of the London-Based Eurosceptic Press," European Studies 20 (2004): 156.

485 National Curriculum: Handbook for Primary School Teachers in England (London: Department for Education and Skills and Qualifications and Curriculum Authority, 1999), 106.

${ }^{486}$ Ibid.
} 
In secondary school, students cover British history from 1066 to 1900 , with their study of 1750 to1900 focusing on "expansion of trade and colonisation." "487 Again, European history is mandated, but only as "[a] study of a significant period or event in the pre-history or history of Europe." 488 The study of European history is, for the most part, focused on Britain's interaction with Europe, not consideration of Britain as a member of Europe. Students are encouraged to think of Britain as separate from continental Europe. Teachers are given the opportunity to teach a European-focused history curriculum, but this approach is not mandated. ${ }^{489}$ The National Curriculum also requires the study of "the cultures, beliefs and achievements of an African, American, Asian or Australasian society in the past" - in other words, the history of one of Britain's old colonies. ${ }^{490}$ Resources developed to aid in the implementation of the curriculum emphasise the interconnectedness between Britain and its colonies, demonstrating the value of these relationships. ${ }^{491}$ As a result, many students are taught British history in a manner that divorces from the wider European world.

Through this approach to history education, British schoolchildren and university students come to assume that Britain is an Atlantic rather than European country. Although Britons may have participated in historical events on the continent, they do not

${ }^{487}$ National Curriculum: Handbook for Secondary School Teachers in England (London: Department for Education and Skills and Qualifications and Curriculum Authority, 1999), 96.

488 Ibid.

${ }^{489}$ Nicola Savvides, "The European Dimension and the National Curriculum for England," in Implementing European Union Education and Training Policy, edited by David Phillips and Hubert Ertl (London: Kluwer, 2003), 147.

$\$ 90$ Ibid.

${ }^{491}$ Often the non-British topics revolve around the United States, an honourary member of Greater Britain." See for examples: "Teacher's Virtual School," Spartacus, accessed October 18, 2011. http:/www.spartacus.schoolnet.co.uk/TVS.htm; "SchoolHistory," accessed October 18, 2011, http://www.schoolhistory.co.uk/resources/; "Learning Teachers," BBC, accessed October 18, 2011, http://www.bbc.co.uk/schools/teachers/; "Keystage History," accessed October 18, 2011, http://www.keystagehistory.co.uk/. 
believe that they have shared the same experiences as the Europeans. Students are taught that Britain and Europe are connected, but fundamentally different. As a result, European integration is interpreted by some as a forced relationship that draws Britain away from a more 'natural' relationship with the United States, one of its former colonies. ${ }^{492}$

Furthermore, language instruction plays a role in reinforcing Britain's difference from the continent. In primary school (key stages 1 and 2), "there is no statutory requirement to teach a modern foreign language." 493 While schools may choose to offer French or German instruction, these classes are only mandatory in key stage $3 .^{494}$ In contrast, French and German schools require all elementary students to study a foreign language. ${ }^{495}$ For the French and Germans, foreign language instruction continues and intensifies throughout secondary school. ${ }^{496}$ British students' lack of foreign language study further reinforces the idea that Britain is fundamentally separate from the continent. Shared language is a foundation of community. If students are not adequately prepared to communicate with other Europeans, they will assume that they share more with the 'Anglosphere' - made up of the Commonwealth and Britain's former colonies - rather than with the European Union.

192 Oliver Daddow, "Euroscepticism and History Education in Britain." Government and Opposition 41, no. 1 (2006): 66.

${ }^{493}$ National Curriculum: Handbook for Primary Teachers, 143.

${ }^{494}$ National Curriculum: Handbook for Secondary School, 108. Key stage 3are students aged 11 to 14. Students are not required to take a modern language in key stage 4, although schools are required to offer at least one European language. National Curriculum: Handbook for Secondary School, 203.

495 "Les programmes de l'école élémentaire," Ministère de l'Éducation nationale, accessed October 18, 2011, http:/www.education.gouv.fr/cid38/presentation-des-programmes-a-l-ecole-elementaire.html. A foreign language is referred to as "langue vivante." In Germany, each state is responsible for its own curriculum, so there is no consistent policy for language instruction. Nonetheless, all states require students to study at least one modem language during their elementary years. For example see "Grundeschule in die Rheinland-Pfaltz: Lernbereiche," accessed October 18, 2011, http://grundschule.bildung-rp.de/lernbereiche.html.

496 "Les programmes du collège." Ministère de l'Éducation nationale, accessed October 18, 2011, http:/www.education.gouv.fr/cid81/les-programmes.html. 
The conception of a 'Greater Britain' continues to persevere in contemporary public discourse. Political and economic links between Britain and other members of the Commonwealth faded in the mid-twentieth century, yet the idea of an English speaking community based on shared language, heritage and values continues to resonate in the twenty-first century. The legacy of the Empire in this imagining of a worldwide British community impedes full participation in European integration, as the European Union ties Britain to the continent rather than the 'Anglosphere.' As in 1962, Britons continue to believe that their country, while geographically part of Europe, is culturally unique. Post-war interpretations of Britain's international role and identity continue to resonate as many Britons maintain that they are "in but not of Europe." 
Appendix: Cartoon Representations of the Franco-German Rapprochement

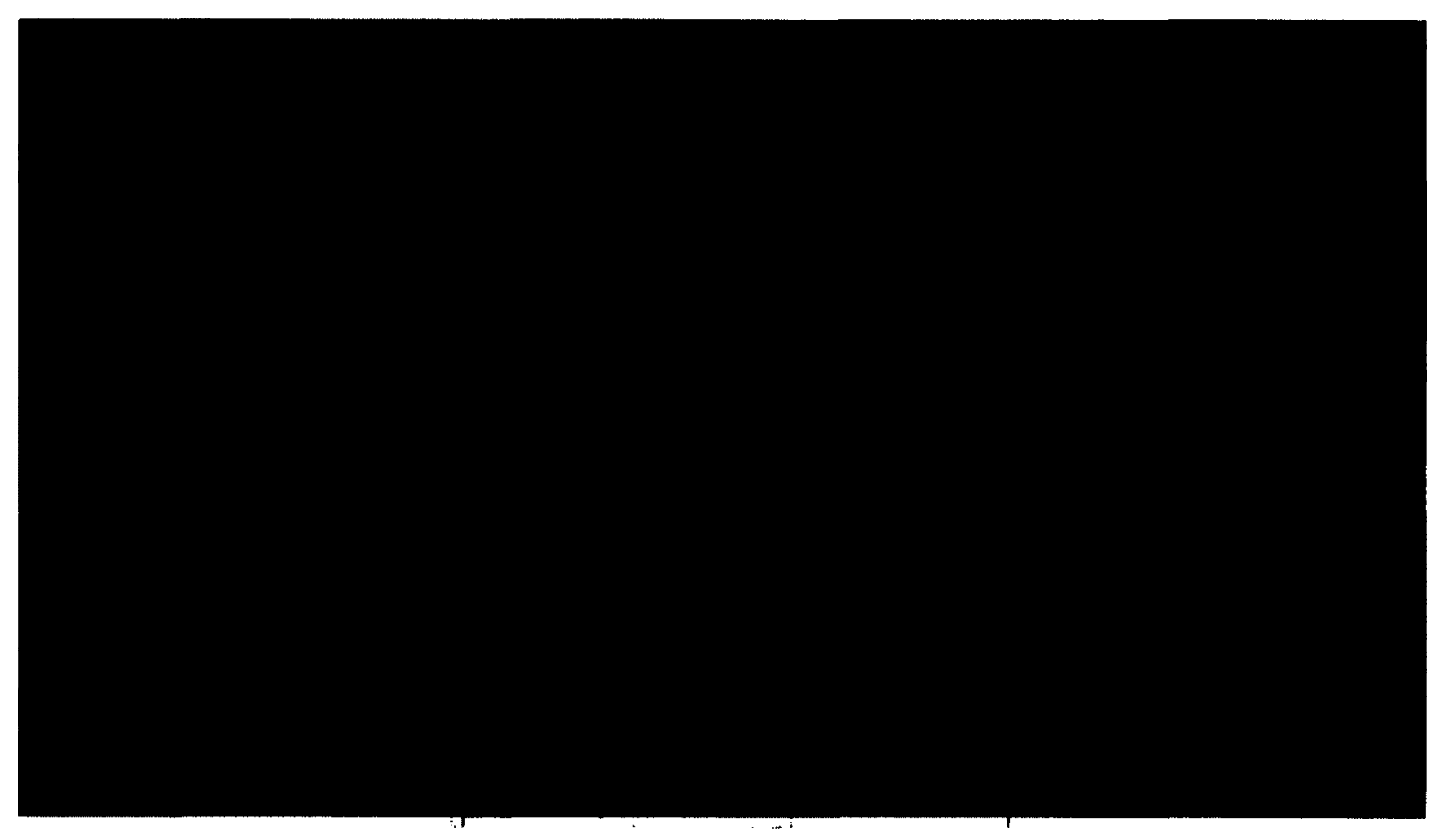

Daily Express, September 6, 1962

Daily Mirror, September 6, 1962 


\section{Bibliography}

\section{Primary Sources}

\section{Archives}

Library and Archives Canada. External Affairs. Canadian Papers Prepared for Prime Ministers' Meeting September 1962, volume 2.

Newspapers and Periodicals

Corriere della Sera [1961-2]

Daily Express $[1962 ; 2010]$

Daily Herald [1962]

Daily Mail [1948]

Daily Mirror [1962]

Economist [2010]

Guardian [1962]

Le Figaro [1962]

Le Monde [1962]

Sïddeutsche Zeitung [1961]

The Times [1959-62; 1985]

\section{Government Publications}

Commonwealth Prime Ministers Meeting, 1962: Final Communiqué. London: Her Majesty's Stationary Office, 1962.

“Grundeschule in die Rheinland-Pfaltz: Lernbereiche." Accessed October 18, 2011. http://grundschule.bildung-rp.de/lernbereiche.html.

"Les programmes de l'école élémentaire." Ministère de l'Éducation nationale. Accessed October 18, 2011. http://www.education.gouv.fr/cid38/presentation-desprogrammes-a-l-ecole-elementaire.html.

"Les programmes du collège," Ministère de l'Éducation nationale. Accessed October 18, 2011. http://www.education.gouv.fr/cid81/les-programmes.html. 
National Curriculum: Handbook for Primary School Teachers in England. London: Department for Education and Skills and Qualifications and Curriculum Authority, 1999.

National Curriculum: Handbook for Secondary School Teachers in England. London: Department for Education and Skills and Qualifications and Curriculum Authority, 1999.

Nations Unies. Annuaire Statistique 1961. New York: Bureau de statistique de l'Organisation des Nations Unies, 1961.

Ottawa Agreements Bill. 1931-32; (127) III.1.

Ross, William David. Royal Commission on the press 1947-49. Report. 1949. XX.1.

Shawcross, W. Hartley. Royal Commission on the press 1961-62. Report. 1962. XXI.1.

\section{Speeches and Pamphlets}

Brown, George. "In a Speech to the 1962 Annual Conference of the Labour Party." Address to the Annual Labour Party Conference, October 3, 1962. In Britain and the Common Market, 24-32. London: Labour, 1962.

Churchill, Winston. Speech to the House of Commons. May 11, 1953. Parliamentary Debates $5^{\text {th }}$ ser., vol. 515 (1953).

De Gaulle, Charles. "Conférence de presse du 14 janvier 1963 (sur l'entrée de la GrandeBretagne dans la CEE)." Accessed October 18, 2011. http://www.ina.fr/fresques/de-gaulle/fiche-media/Gaulle00085/conference-depresse-du-14-janvier-1963-sur-l-entree-de-la-grande-bretagne-dans-la-cee.html.

--------. "Conférence de presse du 27 novembre 1967." Accessed October 18, 2011. http://www.ina.fr/fresques/de-gaulle/fiche-media/Gaulle00139/conference-depresse-du-27-novembre-1967.html

Diefenbaker, John. "Address on what the Commonwealth Represents." March 30, 1962. Accessed November 6, 2010. http://www.collectionscanada.gc.ca/2/4/h4-4016e.html.

Gaitskell, Hugh. "In a Speech to the 1962 Annual Conference of the Labour Party." Address to the Annual Labour Party Conference, October 3, 1962. In Britain and the Common Market, 3-23. London: Labour, 1962.

-----.- Response to the House of Commons, July 31, 1961, Parliamentary Debates $5^{\text {th }}$ ser., vol. 645 (1961).

Grimond, Jo. "Speech to the House of Commons." 29 October, 1959. Parliamentary Debates, Commons, 5th ser., vol. 612 (1959). 
"Labour and the Common Market: Statement by the National Executive Committee $29^{\text {th }}$ September, 1962." In Britain and the Common Market, 33-40. London: Labour Party, 1962.

Macmillan, Harold. "Full Text of Mr. Macmillan's Case for the Common Market," The Times, October 8, 1962.

-.-.-.-.-. "Speech to the Delegates." 81st Annual Conservative Party Conference, Llandudno, October 13, 1962. In The Times, October 15, 1962.

-.-.-.- Speech to the House of Commons. July 31, 1961. Parliamentary Debates $5^{\text {th }}$ ser., vol. 645 (1961).

"Where We Stand: Europe." Conservative Party. Accessed April 5, 2010. http://www.conservatives.com/Policy/Where_we_stand/Europe.aspx.

\section{Collections of Documents and Images}

Behrendt, Fritz. Trotzalledem: Eine Auswahl von 100 politischen Karikaturen. Rotterdam: Nijgh \& van Ditmar, 1963.

Bullen, Roger and Margaret Pelly, eds. Documents on British Foreign Policy Overseas, Series II, Volume I, The Shuman Plan, the Council of Europe and Western European Integration, 1950-52. London: HMSO, 1986.

British Cartoon Archive. http://www.cartoons.ac.uk/

Gordon Mackay papers. European papers and correspondence 1947-1950, MACKAY/5/1. Accessed November 3, 2010. http://www.ena.lu/.

Greenwood, Sean, ed. Britain and European Integration Since the Second World War. Manchester: Manchester University Press, 1996.

Opland. Te kijk bij Opland: een serie politieke spotprenten uit de Volkskrant. Utrecht: De lanteern, 1964.

\section{Teaching Resources}

"Keystage History." Accessed October 18, 2011. http://www.keystagehistory.co.uk/.

"Learning Teachers," BBC. Accessed October 18, 2011. http://www.bbc.co.uk/schools/teachers/.

"SchoolHistory." Accessed October 18, 2011. http://www.schoolhistory.co.uk/resources/.

"Teacher's Virtual School." Spartacus. Accessed October 18, 2011. http://www.spartacus.schoolnet.co.uk/TVS.htm. 


\section{Secondary Sources}

Abraham, Abu. "Anatomy of the Political Cartoon." Indian Horizons 23, no. 1 (1974): 19-27.

Anderson, Benedict. Imagined Communities, revised edition. London and New York: Verso, 2006.

Anderson, Peter J. "A Flag of Convenience? Discourse and Motivations of the LondonBased Eurosceptic Press.” European Studies 20 (2004): 151-170.

Balibar, Etienne. "Algeria, Frace: One Nation or Two." In Giving Ground: The Politics of Propinquity, edited by Ariel Azoulay et al., 162-174. London: Verso, 1999.

Barberis, Peter. Liberal Lion Jo Grimond: A Political Life. London: I.B. Taurus, 2008.

Bell, Duncan. The Idea of Greater Britain: Empire and the Future of World Order, 1860-1900. Princeton: Princeton University Press, 2007.

Berberich, Christine. "I Was Meditating About England': The Importance of Rural England for the Construction of "Englishness'." In History, Nationhood and the Question of Britain, edited by Helen Brocklehurst and Robert Phillips, 375-385. Basingstoke: Palgrave Macmillan, 2004.

Billig, Michael. Banal Nationalism. London: Sage Books, 1995.

Boyce, D. George. Decolonisation and the British Empire, 1775-1997. London: Macmillan, 1999.

Brendon, Piers. The Life and Death of the Press Barons. New York:Atheneum., 1982.

Bridge, Carl and Kent Fedorowich. "Mapping the British World." The Journal of Imperial and Commonwealth History 31, no 2 (May 2003): 1-15.

Brivati, Brian. Hugh Gaitskell. London: Richard Cohen Books, 1996.

Broadcaster's Audience Research Board. Accessed April 17, 2010. http://www.barb.co.uk/facts/tvOwnershipPrivate.

Buckner, Philip. Canada and the British World: Culture, Migration and Identity. Vancouver: UBC Press, 2006.

Burton, Antoinette. "When Was Britain? Nostalgia for the Nation at the End of the 'American Century'," The Journal of Modern History 75 (June 2003): 359-374.

Cairncross, Alec. The British Economy Since 1945: Economic Policy and Performance, 1945-1995, $2^{\text {nd }}$ edition. Oxford: Blackwell, 1995. 
Camp, Miriam. "Missing the Boat at Messina and Other Times." In From Reconstrcution to Integration: Britain and Europe Since 1945, edited by Brian Brivati and Harriet Jones, 134-143. Leicester: Leicester University Press, 1993.

Cannadine, David. "Apocalypse When? British Politicians and British 'Decline' in the Twentieth Century." In Understanding Decline: Perceptions and Realities of British Economic Performance, edited by Peter Clarke and Clive Trebilcock, 261284. Cambridge: Cambridge University Press, 1997.

Ornamentalism: How the British Saw Their Empire. Oxford: Oxford University Press, 2001.

-.-.-.-The Decline and Fall of the British Aristocracy. New Haven, Connecticut: Yale University Press, 1990, Reprint, New York: Vintage Editions, 1999.

"Captain Charles Upham VC \& Bar." The Telegraph. November 23, 1994.

Carr, David. Candymaking in Canada. Toronto: Dundurn, 2004.

Carrey, Sean. "Undivided Loyalties: Is National Identity an Obstacle to European Integration?" European Union Politics 3, no. 4 (2002): 387-413.

Castle, Kathryn. "Imperial Legacies, New Frontiers: Children's Popular Literature and the Demise of Empire." In British Culture and the End of Empire, edited by Stuart Ward, 145-162. Manchester: Manchester University Press, 2001.

Clayton, Anthony. The British Empire as a Superpower, 1919-39. Athens: University of Georgia Press, 1986.

Colley, Linda. "British and Otherness: An Argument." The Journal of British Studies 31, no. 4 (1992): 309-329.

-------. Britons: Forging the Nation, 1707-1837 revised edition. New Haven: Yale University Press, 2009.

Conboy, Martin. The Press and Popular Culture. London: Sage Publications, 2002.

Constantine, Stephen. "British Emigration to the Empire-Commonwealth since 1880: From Overseas Settlement to Diaspora?" Journal of Imperial and Commonwealth History, 31, no. 2 (2003), 16-35.

Crowson, N. J. "Lord Hinchingbrooke, Europe and the November 1962 South Dorset By-election." Contemporary British History 17, no. 4 (Nov. 2003): 43-64.

Cyr, Arthur I. Liberal Politics in Britain, $2^{\text {nd }}$ edition. New Brunswick, New Jersey: Transaction Books, 1988. 
Daddow, Oliver. "Euroscepticism and History Education in Britain." Government and Opposition, 41, no. 1 (2006): 64-85.

"Euroscepticism and the Culture of the Discipline of History," Review of International Studies 32 (2006): 309-328.

-------. Britain and Europe since 1945: Historiographical Perspectives on Integration. Manchester: Manchester University Press, 2004.

Daly, Peter A. "The First British and Danish Applications to Join the EEC, 1960-63." In Britain and Denmark: Political, Economic and Cultural Relations in the 19th and 20th Centuries, edited by Jørgen Sevaldsen, Bo Bjørke and Claus Bjør, 595-616. Copenhagen: Museum Tuscullanum Press, 2003.

De Gaulle, Charles. Mémoires d'espoir, tome I: Le renouveau (1958-1962). Paris: Plon, 1970.

Dobson, Alan. "The Years of Transition: Anglo-American Relations, 1961-1967." Review of International Studies 16, no. 3 (Jul., 1990): 239-258.

Dunae, Patrick. "Boy's Literature and the Idea of Empire, 1870-1914." Victorian Studies 24, no. 1 (1980): 105-121.

Egerton, David. Warfare State: Britain, 1920-1970. Cambridge: Cambridge University Press, 2006.

Forster, Anthony. Euroscepticism in Contemporary British Politics: Opposition to Europe in the British Conservative and Labour Parties since 1945. London: Routledge, 2002.

Gabel, Matthew and Harvey D. Palmer, "Understanding Variation in Public Support for European Integration." European Journal of Political Research 27, no. 1 (1995): 3-15.

Gabel, Matthew. "Public Support for European Integration: An Empirical Test of Five Theories." Journal of Politics 60, no. 2 (1998): 333-354.

George, Stephen. "The Awkward Partner: An Overview." In From Reconstruction to Integration: Britain and Europe Since 1945, edited by Brian Brivati and Harriet Jones, 179-199. Leicester: Leicester University Press, 1993.

Gowland, David and Arthur Turner. Reluctant Europeans: Britain and European Integration, 1945-1998. London: Longman, 2000. 
Granieri, Ronald. The Ambivalent Alliance: Konrad Adenauer, the CDU/CSU, and the West, 1949-1966. New York and Oxford: Berghahn Books, 2003.

Grant, Charles. "Why is Britain Eurosceptic?" Centre for European Reform. Accessed October 17, 2011. http://www.cer.org.uk/sites/default/files/publications/attachments/pdf/2011/essay _eurosceptic_19dec08-1345.pdf.

Grayson, Richard S. Liberals, International Relations, and Appeasement: The Liberal Party, 1919-1939. London: Routledge, 2001.

Griffiths, Richard. "A Slow One Hundred and Eighty Degree Turn: British Policy Towards the Common Market, 1955-60." In Britain's Failure to Enter the European Community, 1961-63, edited by George Wilkes, 35-50. London: Frank Cass \& Co., 1997.

Grimal, Henri. La décolonisation de 1919 à nos jours. Brussels: Éditions complexes, 1985.

Haesly, Richard. "Euroskeptics, Europhiles and Instrumental Europeans: European Attachment in Scotland and Wales." European Union Politics 2, no. 1 (2001): 81-102.

Holland, Robert. "The British Experience of Decolonization." Itinerario 20, no. 2 (1996): 51-63.

Hooghe, Liesbet and Gary Marks. "Does Identity or Economic Rational Drive Public Opinion on European Integration?" PS: Political Science and Politics 37, no. 3 (2004): $415-420$.

Hyam, Ronald. Britain's Declining Empire: The Road to Decolonisation, 1918-1968. Cambridge: Cambridge University Press, 2007.

Hyam, Ronald and Peter Henshaw. The Lion and the Springbok: Britain and South Africa since the Boer War. Cambridge: Cambridge University Press, 2003.

Imlah, Albert Henry. Economic Elements in the Pax Britannica: Studies in British Foreign Trade in the Nineteenth Century. Cambridge, Mass.: Harvard University Press, 1958.

Jacobs, Dirk and Robert Maier, "European Identity: Construct, Fact and Fiction." In $A$ United Europe: The Quest for a Multifaceted Identity, edited by Marja Gastelaars and Arie de Ruijter, 13-34. Maastricht [Netherlands]: Shaker Publishing, 1998. 
Johnston, Mary Troy. "Britain and Transatlantic Security: Negotiating Two Bridges Far Apart." In Old Europe, New Europe And The Us: Renegotiating Transatlantic Security In The Post 9/11 Era, edited by Tom Langsford and Blago Tashev, 4156. Aldershot: Ashgate Publishers, 2004.

Jonung, Lars. "The Political Economy of Monetary Unification: The Swedish Euro Referendum of 2003." Cato Journal 24, no. 1-2 (2004): 123-149.

Kaiser, Wolfram. "To Join or Not to Join: The 'Appeasement' Policy of Britain's First EEC Application." In From Reconstruction to Integration: Britain and Europe Since 1945, edited by Brian Brivati and Harriet Jones, 144-156. Leicester: Leicester University Press, 1993.

Kemnitz, Thomas Milton. "The Cartoon as a Historical Source." The Historian and the Arts 4, no. 1, (Summer, 1973): 81-93.

Kirk-Greene, Anthony. "African Rhodes Scholars, 1960-1990." In Africans in Britain, edited by David Killingray, 220-235. New York: Frank Cass, 1994.

Koss, Stephen. The Rise and Fall of the Political Press in Britain: Twentieth Century. Chapel Hill: University of North Carolina Press, 1984.

Kuhn, Raymond. The Media in France. London Routledge, 1995.

Kumar, Krishan. "English and British National Identity." History Compass 4, no. 3 (2006): $428-447$.

Lamb, Richard. The Macmillan Years, 1957-1963: The Emerging Truth. London: John Murray, 1995.

Le, Elisabeth. Editorials and the Power of Media: Interweaving of Socio-cultural Identities. Philadelphia: John Benjamins Pub. Company, 2010.

Lee, Mark. "The Story of Greater Britain: What Lessons Does It Teach?" National Identities 6, no. 2 (2004): 123-142.

Louis, Wm. Roger. "The Dissolution of the British Empire." In Oxford History of the British Empire: The Twentieth Century, edited by Judith Brown and Wm. Roger Louis, 329-356. Oxford: Oxford University Press, 1999.

Ludlow, N. Piers. Dealing with Britain: The Six and the First UK Application to the $E E C$. Cambridge: Cambridge University Press, 1997.

Lunn, Ken and Ann Day. "Britain as Island: National Identity and the Sea." In History, Nationhood and the Question of Britain, edited by Helen Brocklehurst and Robert Phillips, 124-136. New York: Palgrave MacMillan, 2004. 
MacKenzie, John M. "Empire and Metropolitan Cultures." In The Oxford History of the British Empire: The Nineteenth Century, edited by Andrew Porter, 270-293. Oxford: Oxford University Press, 1999.

May, Alex. Britain and Europe Since 1945. London: Longman, 1998.

McKercher, B. J. C. Transition of Power: Britain's Loss of Global Pre-eminence to the United States. Cambridge: Cambridge University Press, 2004.

Michaud, Yves, ed. La guerre d'Algérie (1954-1962). Paris: Odile Jacob, 2004.

Montgomery, Bo Gabriel. Pax Britannica. London: Methuen \& Co. 1928.

Morris, James. Farewell the Trumpets: An Imperial Retreat. London: Faber, 1978.

-----.-. Heaven's command: An Imperial Progress. London: Farber, 1973.

-...-... Pax Britannica: Climax of an Empire. New York: Harcourt, Brace \& World, 1968.

Oakland, John. British Civilization: An Introduction $5^{\text {th }}$ edition. London: Routledge, 2002.

Obama, Barack. "Remarks by the President to Parliament in London, United Kingdom." Speech to Westminster Hall, London, May 25, 2011. Accessed October 16, 2011. http://www.whitehouse.gov/the-press-office/2011/05/25/remarks-presidentparliament-london-united-kingdom.

Palmeri, Frank. "The Cartoon: The Image as Critique." In History Beyond the Text, edited by Sarah Barber and Corinna M. Peniston-Bird, 32-48. New York: Routledge, 2009.

Paris, Michael. Warrior Nation. London: Reaktion Books, 2000.

Paul, Kathleen. "Communities of Britishness: Migration in the Last Gasp of Empire." In British Culture and the End of Empire, edited by Stuart Ward, 180-199. Manchester: Manchester University Press, 2000.

Pemberton, Hugh. “A Taxing Task: Combating Britain's Relative Decline in the 1960s." Twentieth Century British History 12, no. 3 (2001): 354-375.

Pittock, Murray. Inventing and Resisting Britain: Cultural Identities in Britain and Ireland, 1685-1789. New York: St. Martin's Press, 1997.

Porter, Andrew. "Barack Obama and David Cameron to Rename Special Relationship the 'Essential Relationship'." Telegraph, May 24, 2011.

Porter, Bernard. "The Empire Strikes Back." History Today 46, no. 9 (1996): 11-13. 
--.-.-.. The Lion's Share: A Short History of British Imperialism. Harlow: Longman, 1996.

"Pourquoi le Royaume-Uni est-il eurosceptique?" EurActive Network. Accessed April 6, $2010 . \quad \mathrm{http}: / / \mathrm{www}$.euractiv.com/fr/affaires-publiques/royaume-unieurosceptique/article-178328.

Rallings, Colin and Michael Thrasher. British Electoral Facts, 1832-2006. Aldershot: Ashgate, 2007.

Rapson, Edward James. The Struggle Between England and France for Supremacy in India. London: Trübner \& Co, 1887.

Richards, Huw. "The Daily Herald: 1912-1964." History Today 31, no.12 (1981): 1216.

Richard, Jeffrey. Films and British National Identity: From Dickens to Dad's Army. Manchester: Manchester University Press, 1997.

Robbins, Keith. “'The 'British Space': World-Empire-Continent-Nation-RegionLocality: A Historiographical Problem." History Compass 7, no. 1 (2009): 66-94.

Ross, Kristin. Fast Cars, Clean Bodies: Decolonization and the Reordering of French Culture. Cambridge, Mass: MIT Press, 1995.

Salmon, Patrick. Scandinavia and the Great Powers, 1890-1940. Cambridge: Cambridge University Press, 1997.

Salvadó, Francisco J. Romero. Twentieth-Century Spain: Politics and Society in Spain, 1898-1998. Basingstoke: Palgrave, 1999.

Samuel, Raphael ed. Patriotism: The Making and Unmaking of British National Identity. London: Routledge, 1989.

Savvides, Nicola. "The European Dimension and the National Curriculum for England." In Implementing European Union Education and Training Policy, edited by David Phillips and Hubert Ertl, 143-160. London: Kluwer, 2003.

Seymour-Ure, Colin. "How Special Are Cartoonists?" Twentieth Century Studies 13, no. 14 (1975): 6-21.

Shearman, Peter. "Britain, the European Union and National Identity." In Britain in Europe: Prospects for Change, edited by John Milfull, 91-102. Aldershot: Ashgate, 1999.

Shepard, Todd. The Invention of Decolonization: The Algerian War and the Remaking of France. Ithaca, N.Y.: Cornell University Press, 2006. 
Sloan, Stanley R. NATO, the European Union, and the Atlantic Community: The Transatlantic Bargain Reconsidered. Lanham, MD: Rowman \& Littlefield Publishers, 2002.

Smith, Tony. "A Comparative Study of French and British Decolonization." Comparative Studies in Society and History 20, no. 1 (Jan. 1978): 70-102.

Spence, James. "Movements in the Public Mood, 1961-1975." In Britain Into Europe: Public Opinion and the E.E.C., 1961-1975, edited by Roger Jowell and Gerald Hoinville, 18-36. London: Social and Planning Research, 1976.

Stead, W.T. "Government by Journalism." The Contemporary Review, vol. 49 (1886): 653-674.

Stockwell, A.J. "“A Widespread and Long-Concocted Plot to Overthrow the Government in Malaya'? The Origins of the Malayan Emergency." In Emergencies and Disorder in the European Empires After 1945, edited by Robert Holland, 66-88. London: Frank Cass \& Co., 1994.

Sutherland, Marcia E. "African Caribbean Immigrants in the United Kingdom: The Legacy of Racial Disadvantages," Caribbean Quarterly 52 (2006), 26-52.

Tabili, Laura. “A Homogenous Society? Britain's Internal 'Others,' 1800-Present.” In At Home with the Empire: Metropolitan Culture and the Imperial World, edited by Catherine Hall and Sonya Rose, 53-76. Cambridge: Cambridge University Press, 2007.

“The Press: As Le Monde Turns," Time, December 26, 1969.

Thomas, James. Popular Newspapers, the Labour Party and British Politics. New York: Routledge, 2005.

Vaïsse, Maurice. "De Gaulle and the British 'Application" to Join the Common Market," in Britain's Failure to Enter the European Community, 1961-1963, edited by George Wilkes, 51-70. London: Frank Cass \& Co., 1997.

Voigt, Fritz August. Pax Britannica. London: Constable, 1949.

Ward, Stuart. "The End of Empire and the Fate of Britishness." In History, Nationhood and the Question of Britain, edited by Helen Brocklehurst and Robert Phillips, 242-258. New York: Palgrave MacMillan, 2004.

Australia and the British Embrace: The Demise of the Imperial Ideal. Carlton South: Melbourne University Press, 2001.

Weight, Richard. Patriots: National Identity in Britain 1940-2000. London: Macmillan, 2002. 
Wiener, Martin J. Men of Blood: Violence, Manliness and Criminal Justice in Victorian Britain. Cambridge: Cambridge University Press, 2004.

Wilkes, George and Dominic Wring. "The British Press and European Integration, 19481996." In Britain For and Against Europe: British Politics and the Question of European Integration, edited by David Baker and David Seawright, 185-205. Oxford: Clarendon Press, 1998.

Wilkes, George. "The First Failure to Steer Britain into the European Communities: An Introduction." In Britain's Failure to Enter the European Community, 1961-63, edited by George Wilkes, 1-34. London: Frank Cass \& Co., 1997.

Wintour, Charles. The Rise and Fall of Fleet Street. London: Hutchinson, 1989.

Woodham, Jonathon. "Images of Africa and Design at the British Empire Exhibitions between the Wars." Journal of Design History 2, no.10 (1989): 15-33.

Wurm, Clemens A. "Great Britain: Political Parties and Pressure Groups in the Discussion on European Union." In Documents on the History of European Integration Volume Three: The Struggle for European Union by Political Parties and Pressure Groups in Western European Countries, 1945-1950, edited by Walter Lipgens and Wilfried Loth, 628-762. European University Institute: New York, 1988.

Yack, Bernard. "The Myth of the Civic Nation," Critical Review 10, no. 2 (Spring 1996): 193-211.

Yonwin, Jessica. UK Election Statistics: 1918-2004. Westminster: House of Commons Library, 2004.

Young, John W. "Britain and the EEC, 1956-73: An Overview." In From Reconstruction to Integration: Britain and Europe Since 1945, edited by Brian Brivati and Harriet Jones, 103-113. London: Leicester University Press, 1997.

\section{Tertiary Sources}

Boyce, D. George. “Aitken, William Maxwell, first Baron Beaverbrook (1879-1964)." Oxford Dictionary of National Biography, Oxford University Press, 2004; online edition, Jan 2011. Accessed May 14, 2011.

http://www.oxforddnb.com.proxy.library.carleton.ca/view/article/30358.

Griffiths, Richard. "Bryant, Sir Arthur Wynne Morgan (1899-1985)." Oxford Dictionary of National Biography. Oxford University Press, 2004; online edition, Jan 2011. Accessed July 22, 2011.

http://www.oxforddnb.com.proxy.library.carleton.ca/view/article/30867.

Dyck, Rand. Canadian Politics, $5^{\text {th }}$ edition. Toronto: Nelson, 2009. 
Matthew, H. C. G. "Macmillan, (Maurice) Harold, first earl of Stockton (1894-1986)." Oxford Dictionary of National Biography, Oxford University Press, 2004; online edn, Jan 2011. Accessed November 14, 2011.

http://www.oxforddnb.com.proxy.library.carleton.ca/view/article/40185. 